University of South Florida

DIGITAL COMMONS

@ UNIVERSITY OF SOUTH FLORIDA
Digital Commons @ University of

South Florida

$11-1-2015$

\title{
National Transit Demand Response level of Service
}

CUTR

Follow this and additional works at: https://digitalcommons.usf.edu/cutr_nctr

\section{Recommended Citation}

"National Transit Demand Response level of Service," National Center for Transit Research (NCTR) Report No. CUTR-NCTR-RR-2015-14, Center for Urban Transportation Research, University of South Florida, 2015. DOI: https://doi.org/10.5038/CUTR-NCTR-RR-2015-14

Available at: https://scholarcommons.usf.edu/cutr_nctr/31

This Technical Report is brought to you for free and open access by the National Center for Transit Research (NCTR) Archive (2000-2020) at Digital Commons @ University of South Florida. It has been accepted for inclusion in Research Reports by an authorized administrator of Digital Commons @ University of South Florida. For more information, please contact digitalcommons@usf.edu. 


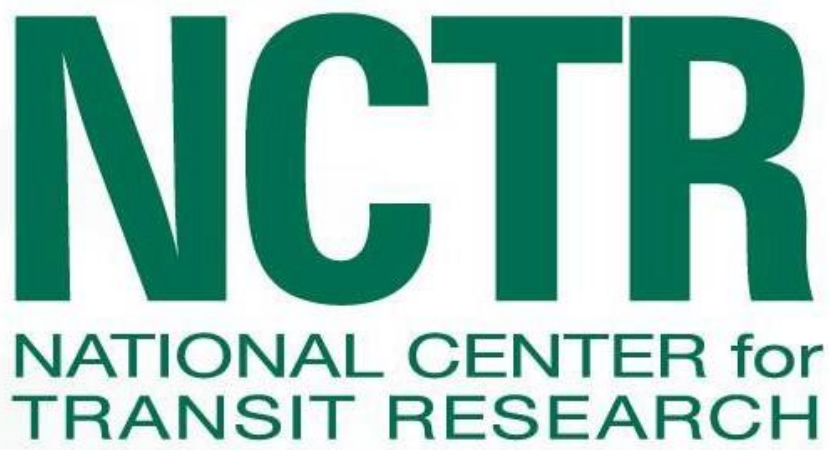

\section{Developing a Method for Assessing National Demand-Response Transit Level of Service}

October 2015

PROJECT NO.

2117-7060-NCTR-NDSU06

PREPARED BY

Ranjit Godavarthy

Jeremy Mattson

Patrick Nichols

Del Peterson Jill Hough

North Dakota State University Upper Great Plains Transportation Institute

Small Urban and Rural Transit Center

PREPARED FOR

National Center for Transit Research (NCTR) 


\section{Disclaimer}

The contents of this report reflect the views of the authors, who are responsible for the facts and the accuracy of the information presented herein. This document is disseminated under the sponsorship of the Department of Transportation University Transportation Centers Program and the Florida Department of Transportation, in the interest of information exchange. The U.S. Government and the Florida Department of Transportation assume no liability for the contents or use thereof.

The opinions, findings, and conclusions expressed in this publication are those of the authors and not necessarily those of the State of Florida Department of Transportation. 


\title{
Developing a Method for Assessing National Demand-Response Transit Level of Service
}

\author{
Prepared for: \\ Prepared by: \\ Ranjit Godavarthy \\ Jeremy Mattson \\ Patrick Nichols \\ Del Peterson \\ Jill Hough
}

U.S. Department of Transportation

Small Urban and Rural Transit Center

Upper Great Plains Transportation Institute

North Dakota State University

Fargo, ND

\section{Final Report \\ 21177060-NCTR-NDSU06 \\ October 2015}

\begin{abstract}
National Center for Transit Research
A USDOT Transit-focused University Transportation Center consortium led by University of South Florida
\end{abstract}

4202 E. Fowler Avenue, CUT100, Tampa FL 33620-5375 www.nctr.usf.edu

Member universities: University of South Florida, North Dakota State University, University of Illinois at Chicago, Florida International University 


\section{Metric Conversion}

\begin{tabular}{|c|c|c|c|c|}
\hline SYMBOL & WHEN YOU KNOW & MULTIPLY BY & TO FIND & SYMBOL \\
\hline \multicolumn{5}{|c|}{ LENGTH } \\
\hline in & inches & 25.4 & millimeters & $\mathrm{mm}$ \\
\hline ft. & feet & 0.305 & meters & $\mathrm{m}$ \\
\hline yd. & yards & 0.914 & meters & $\mathrm{m}$ \\
\hline mi & miles & 1.61 & kilometers & $\mathrm{km}$ \\
\hline \multicolumn{5}{|c|}{ VOLUME } \\
\hline fl. oz. & fluid ounces & 29.57 & milliliters & $\mathrm{mL}$ \\
\hline gal & gallons & 3.785 & liters & L \\
\hline $\mathrm{ft}^{3}$ & cubic feet & 0.028 & cubic meters & $\mathrm{m}^{3}$ \\
\hline$y d^{3}$ & cubic yards & 0.765 & cubic meters & $\mathrm{m}^{3}$ \\
\hline \multicolumn{5}{|c|}{ NOTE: volumes greater than $1000 \mathrm{~L}$ shall be shown in $\mathrm{m}^{3}$} \\
\hline \multicolumn{5}{|c|}{ MASS } \\
\hline oz. & ounces & 28.35 & grams & g \\
\hline lb. & pounds & 0.454 & kilograms & $\mathrm{kg}$ \\
\hline $\mathbf{T}$ & Short tons (2000 lb.) & 0.907 & $\begin{array}{c}\text { megagrams } \\
\text { (or "metric ton") }\end{array}$ & Mg (or "t") \\
\hline \multicolumn{5}{|c|}{ TEMPERATURE (exact degrees) } \\
\hline${ }^{\circ} \mathbf{F}$ & Fahrenheit & $\begin{array}{c}5(F-32) / 9 \\
\text { or }(F-32) / 1.8\end{array}$ & Celsius & ${ }^{\circ} \mathrm{C}$ \\
\hline
\end{tabular}




\section{Technical Report Documentation}

\begin{tabular}{|l|l|l|}
\hline $\begin{array}{l}\text { 1. Report No. } \\
\text { 2117-7060-NCTR-NDSU06 }\end{array}$ & 2. Government Accession No. Recipient's Catalog No. \\
\hline $\begin{array}{l}\text { 4. Title and Subtitle } \\
\begin{array}{l}\text { Developing a Method for Assessing National Demand- } \\
\text { Response Transit Level of Service }\end{array}\end{array}$ & $\begin{array}{l}\text { 5. Report Date } \\
\text { October } 2015\end{array}$ \\
\hline
\end{tabular}

\section{Performing Organization Code}

\section{Author(s) \\ Ranjit Godavarthy, Jeremy Mattson, Patrick Nichols, Del Peterson, Jill Hough \\ North Dakota State University, Upper Great Plains \\ Transportation Institute, Small Urban and Rural Transit Center}

\section{Performing Organization Name and Address}

National Center for Transit Research

Center for Urban Transportation Research (CUTR)

University of South Florida

4202 East Fowler Avenue, CUT100

Tampa, FL 33620-5375

11. Contract or Grant No.

\section{Sponsoring Agency Name and Address}

Research and Innovative Technology Administration

U.S. Department of Transportation

Mail Code RDT-30, 1200 New Jersey Ave SE, Room E33

Washington, DC 20590-0001

14. Sponsoring Agency Code

\section{Supplementary Notes}

\section{Abstract}

Demand-response transit service is a major source of mobility for older adults and people with disabilities in urban and rural areas. Federal Transit Administration (FTA) grant programs under sections 5307, 5310, and 5311 all have components designed to increase the availability of paratransit or demand-response service. However, there is little information in the National Transit Database (NTD) or elsewhere about the extent of demandresponse coverage across the country. Therefore, it is challenging to know the gaps in service coverage and to understand unmet needs. The primary objective of the study is to fill the gaps in the data available from the NTD database to determine the demand-response transit level of service. Also, this study aims to develop a standard method for determining the demand-response service level of coverage so that geographic areas/locations that do not have sufficient demand-response transit service can be identified. A survey questionnaire was developed to gather important information such as service span, service area, service type, and service eligibility from demand-response operators to determine the demand-response transit level of service. The survey was tested in two states, North Dakota and Florida, for its applicability in the rest of the country, and recommendations were provided for gathering additional service details for determining the national demand-response transit level of service. Based on the results from the study, recommendations were provided regarding data needs, an appropriate method for collecting those data, and a framework for understanding the communities/locations where demand-response service improvements are needed. The recommended framework will provide useful information to transit agencies, metropolitan planning organizations, and state departments of transportation for identifying deficiencies in service while minimizing the reporting burden for transit providers.
17. Key Words

\section{Distribution Statement}

Demand-response, Section 5307, Section 5310, Section

5311 , transit level of service

No restrictions

\begin{tabular}{l|l}
$\begin{array}{l}\text { 19. Security Classification } \\
\text { (of this report) }\end{array}$ & $\begin{array}{l}\text { 20. Security Classification } \\
\text { (of this page) }\end{array}$ \\
Unclassified & Unclassified
\end{tabular}

21. No. of Pages

72
22. Price 


\section{TABLE OF CONTENTS}

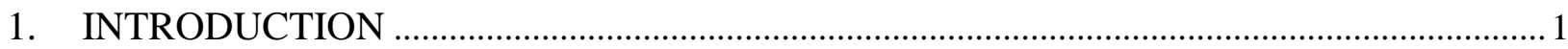

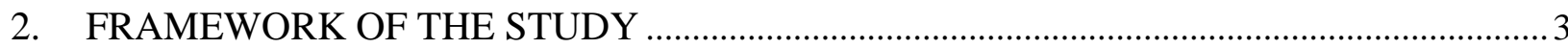

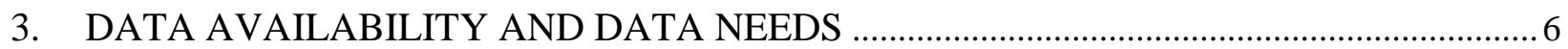

4. TEST SURVEY OF NORTH DAKOTA TRANSIT AGENCIES ………………...................

4.1 Developing and Administering the Survey ........................................................................ 8

4.2 Map Tool Used for the Study ..................................................................................... 9

4.3 Survey Results Summary ………………………………………………………..... 11

4.3.1 Type of Service Provided .................................................................................. 11

4.3.2 Service Span and Coverage ........................................................................ 11

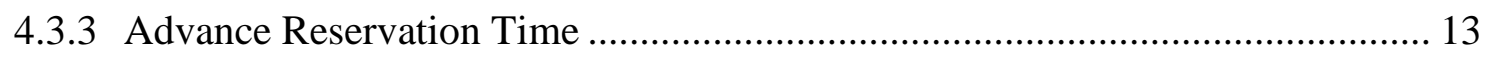

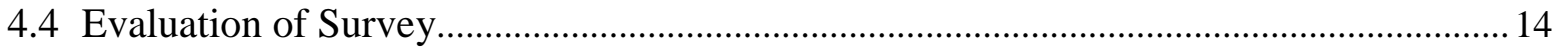

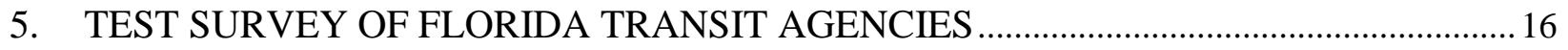

5.1 Developing and Administering the Survey ...................................................................... 16

5.2 Mapping Florida Level of Service Data ........................................................................... 19

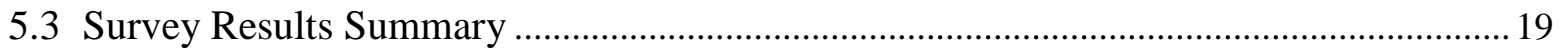

5.3.1 Type of Service Provided................................................................................ 19

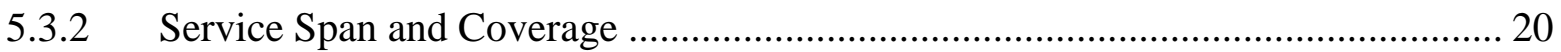

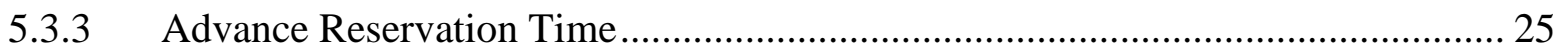

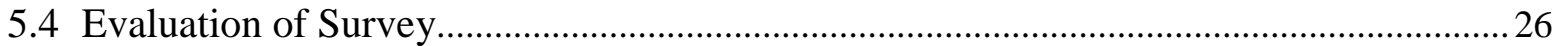

6. PRIORITY RANKING FOR DEMAND-RESPONSE TRANSIT SERVICE

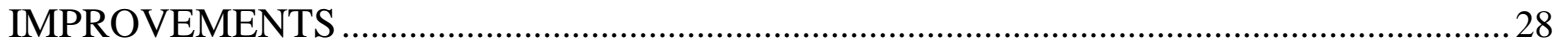

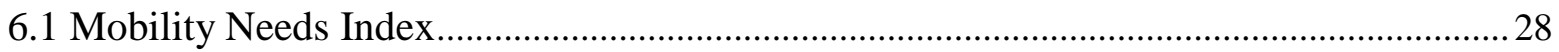

6.2 Identifying Priorities for Service Improvements .................................................................. 30

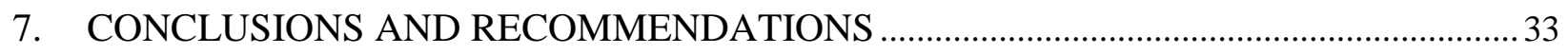

7.1 National Demand-Response Transit Level of Service Study Framework ..........................33

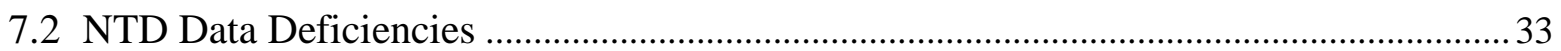

7.3 Survey of Demand-Response Transit Agencies in North Dakota and Florida...................33

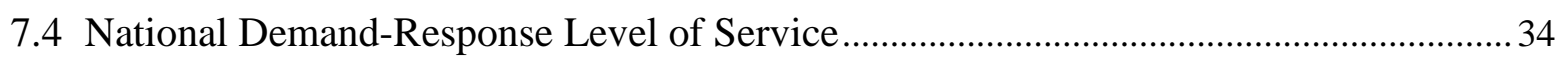

7.5 Priority Ranking for Receiving Demand-Response Service Improvements ......................35

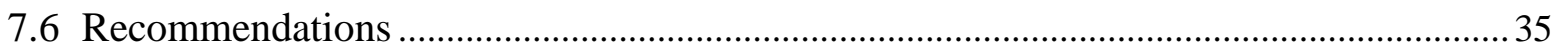

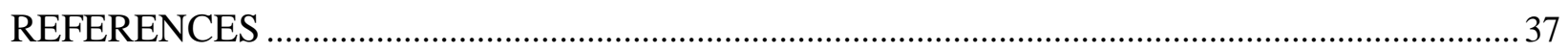

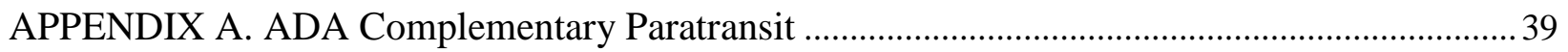


APPENDIX B. Survey Tool Used for Demand-Response Level of Service Study -

North Dakota

APPENDIX C. Framework for Developing the Survey and the Map Tool for North Dakota

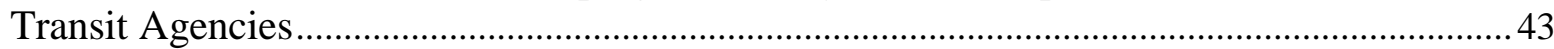

APPENDIX D. Survey Tool Used for Demand-Response Level of Service Study - Florida ........ 44

APPENDIX E. Detailed Data for Florida ………………………………………………………..... 50 


\section{LIST OF FIGURES}

Figure 4.1 North Dakota State Map with Census Tract Areas vs. Zip Code Areas ................ 10

Figure 4.2 Days per Week of Demand-Response Transit Service in North Dakota ................ 12

Figure 4.3 Hours per Service Day for Demand-Response Transit Service in North Dakota.... 12

Figure 4.4 Demand-Response Transit Level of Service in North Dakota.............................. 13

Figure 5.1 Days of Service per Week for Demand-Response Transit in Florida, Including All Types of Services ............................................................................. 21

Figure 5.2 Hours of Service per Day for Demand-Response Transit in Florida, Including

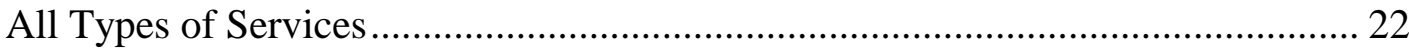

Figure 5.3 Days of Service per Week for Demand-Response Transit in Florida for the General Public

Figure 5.4 Hours of Service per Day for Demand-Response Transit in Florida for the General Public

Figure 5.5 Level of Service for Demand-Response Transit in Florida, Including All Types of Services

Figure 5.6 Level of Service for Demand-Response Transit in Florida for the General Public. 25

Figure 5.7 Florida Transit Agency Opinions Regarding the Ease of Completing the Survey .. 27

Figure 6.1 Mobility Needs Index for North Dakota .......................................................... 29

Figure 6.2 Mobility Needs Index for Florida 29

Figure 6.3 Priority Ranking for Receiving Demand-Response Service Improvements in North Dakota

Figure 6.4 Priority Ranking for Receiving Demand-Response Service Improvements in Florida 


\section{LIST OF TABLES}

Table 2.1 Level of Service Measures for Demand-Response Service Based on Service Span........................................................................................................... 4

Table 2.2 Level of Service Measure for Demand-Response Transit Service Based on

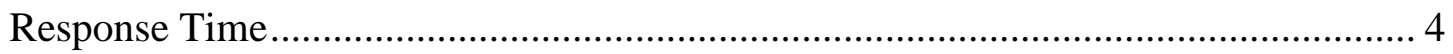

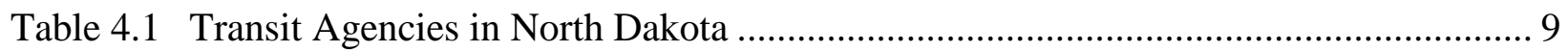

Table 4.2 What type of transportation services does your organization provide......................... 11

Table 4.3 Do you provide the following types of service........................................................ 11

Table 4.4 What is the minimum advance reservation time for your agency operating demand-response or complementary paratransit?..................................................... 14

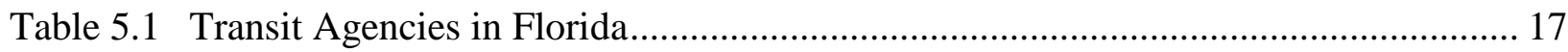

Table 5.2 What type of transportation services does your organization provide......................... 20

Table 5.3 Do you provide the following types of service........................................................ 20

Table 5.4 What is the minimum advance reservation time for your agency operating demand-response or complementary paratransit? ................................................... 26

Table 6.1 Priority Ranking Measure for Demand-Response Transit Service Improvements..... 30 


\section{ABSTRACT}

Demand-response transit service is a major source of mobility for older adults and people with disabilities in urban and rural areas. Federal Transit Administration (FTA) grant programs under sections 5307, 5310, and 5311 all have components designed to increase the availability of paratransit or demand-response service. However, there is little information in the National Transit Database (NTD) or elsewhere about the extent of demand-response coverage across the country. Therefore, it is challenging to know the gaps in service coverage and to understand unmet needs.

The primary objective of the study is to fill the gaps in the data available from the NTD database to determine the demand-response transit level of service. Also, this study aims to develop a standard method for determining the demand-response service level of coverage so that geographic areas/locations that do not have sufficient demand-response transit service can be identified. A survey questionnaire was developed to gather important information such as service span, service area, service type, and service eligibility from demand-response operators to determine the demand-response transit level of service. The survey was tested in two states, North Dakota and Florida, for its applicability in the rest of the country, and recommendations were provided for gathering additional service details for determining the national demandresponse transit level of service.

Based on the results from the study, recommendations were provided regarding data needs, an appropriate method for collecting those data, and a framework for understanding the communities/locations where demand-response service improvements are needed. The recommended framework will provide useful information to transit agencies, metropolitan planning organizations, and state departments of transportation for identifying deficiencies in service while minimizing the reporting burden for transit providers. 


\section{EXECUTIVE SUMMARY}

Demand-response transit (DRT) service is a major source of mobility for older adults and people with disabilities in urban and rural areas. DRT operates based on individual requests or demands for transportation service. DRT vehicles pick up and drop off people at desired origins and destinations by providing door-to-door or curb-to-curb service. Types of DRT services include DRT for the general public, ADA complementary paratransit, limited-eligibility DRT, and human service transportation. While DRT is a critical component of a community's transit system, the data needed to assess the level of service being provided is lacking.

To assess DRT service coverage, level of service, system performance, and unmet needs requires detailed data regarding existing services. Some of these data can be obtained from the National Transit Database (NTD), which is a standard reporting system for urban and rural transit providers. However, there is little information in the NTD or elsewhere about the extent of DRT coverage and level of service across the country, which makes it difficult to identify gaps in service coverage and to understand unmet needs.

The objectives of this study are to identify data needs for assessing DRT level of service, develop a data collection tool for obtaining those data, develop a method for assessing DRT levels of service and prioritizing needs for service improvements, and provide recommendations for constructing a DRT level of service survey tool that could be used in any state or nationwide.

The methods developed were tested in two pilot states: North Dakota and Florida. These two states were chosen because they provide a mix of geographic types. Testing the framework in a mix of large urban, small urban, suburban, and rural areas could ensure that the effort would be successful if applied nationwide.

\section{Quality of Service Measures and Data Deficiencies}

Key variables for identifying the level of DRT service across the country include geographic coverage, days of service per week, hours of service per day, advance reservation requirements, and service eligibility. These data are largely missing from the NTD. Service span and geographic coverage are two variables that are especially important but which have limited data availability. While the NTD has data for service days and hours for some transit agencies, service span data for DRT service is not available for any agency in the rural NTD.

With regard to geographic coverage data, very general service area (city, or counties served) information is available for some transit agencies in the NTD, but the data available are not specific or precise and are therefore inadequate for the study methodology. In the rural NTD, agencies are asked to identify the county or counties in which they provide service. Some of the multi-county providers do not list all of their counties, so the data are incomplete. The data are also imprecise because an agency might not provide service within some areas of the county, or the level of service provided may differ within the county. Some areas might receive daily service, while others have service twice a week. Geographic coverage and level of service information at a level finer than the county would be helpful. This level of information is not available through the NTD. More detail regarding ADA paratransit service areas would also be 
useful. ADA paratransit providers may offer service within $3 / 4$ miles of fixed-route service, as required, or they may provide service to a larger geographic area.

Further, the availability of additional service data for DRT agencies such as minimum advance reservation time, eligibility for using demand-response service and/or ADA paratransit service, and type of DRT service provided (curb-to-curb, door-to-door, etc.) would be helpful for identifying the type and level of service being provided. These data also are not available from the NTD. A significant limitation of the NTD is that it does not distinguish ADA paratransit from general public DRT and other forms of demand-response services.

\section{Survey of Demand-Response Transit Agencies in North Dakota and Florida}

Given that currently available data sources are inadequate, this study developed and conducted online surveys of DRT agencies in North Dakota and Florida to gather necessary service details. While the two surveys employed different approaches, both attempted to collecte detailed data on geographic coverage and level of service, including service eligibility, service days per week, service hours per day, service area, service type, and minimum advance reservation time. The goal in designing these surveys was to collect as much useful and detailed data as possible while minimizing the burden to transit agencies and the possibility for error.

A total of 27 out of 33 transit agencies in North Dakota responded to the first survey. The high response rate was influenced by the NDDOT requesting the agencies to respond. The online survey tool used a map tool that responding transit agencies could click on to indicate the geographic areas (census tracts/cities) where they offered any kind of DRT service. While the survey was mostly successful, the use of the clickable map tool in the survey was found to be somewhat ineffective.

Based on the lessons learned with the first survey, the survey was redesigned before being sent to DRT agencies in Florida. While the rest of the survey questionnaire was similar to the North Dakota survey, the clickable map tool was discarded and information on service area was gathered using a different approach. Transit agencies were first asked to identify counties in which they provide demand-response service. Then for the individual county or counties selected, the survey asked if the agency provides the same days and hours of service throughout the county or if some areas are unserved or provided different levels of service. If service is the same throughout the county, the survey asked agencies to identify the number of days and hours of service provided in the county. If service differs, the survey then listed each city in the county and asked respondents to identify the number of days and hours of service for each city. Rural areas of the county not belonging to any city were also included in the survey and referred to as "other rural areas."

Of the 56 transit agencies in Florida, 38 responded to the survey. A lower response rate was obtained because the Florida DOT was not involved in distributing the survey, but despite the lower response rate, the survey conducted in Florida was more successful. The survey collected a high level of detail regarding geographic coverage and span of service, it was less prone to error than the North Dakota survey, and feedback from transit agencies in Florida was more positive. Most responding agencies from Florida said that the survey was easy to complete, and very few 
mentioned any difficulties with the survey. Further, most agencies completed the survey within 5-15 minutes.

\section{Mapping Demand-Response Level of Service}

The data collected in these surveys provide a greater description of DRT levels of service than what is currently available in the NTD. Data for days per week and hours per day of service were collected at city or census tract levels and illustrated in statewide maps. Days per week and hours per day of service can also be combined into a single measure of level of service, as developed in the $2^{\text {nd }}$ edition of the Transit Capacity and Quality of Service Manual (TCQSM). Using this approach, Figures 1 and 2 map existing levels of service (LOS) for all types of DRT agencies in North Dakota and Florida. The highest level of service (LOS 1) consists of service six or seven days per week and 16 or more hours per day; the lowest level (LOS 8) indicates very limited service (less than weekly) or no service; and other levels represent varying levels of service.

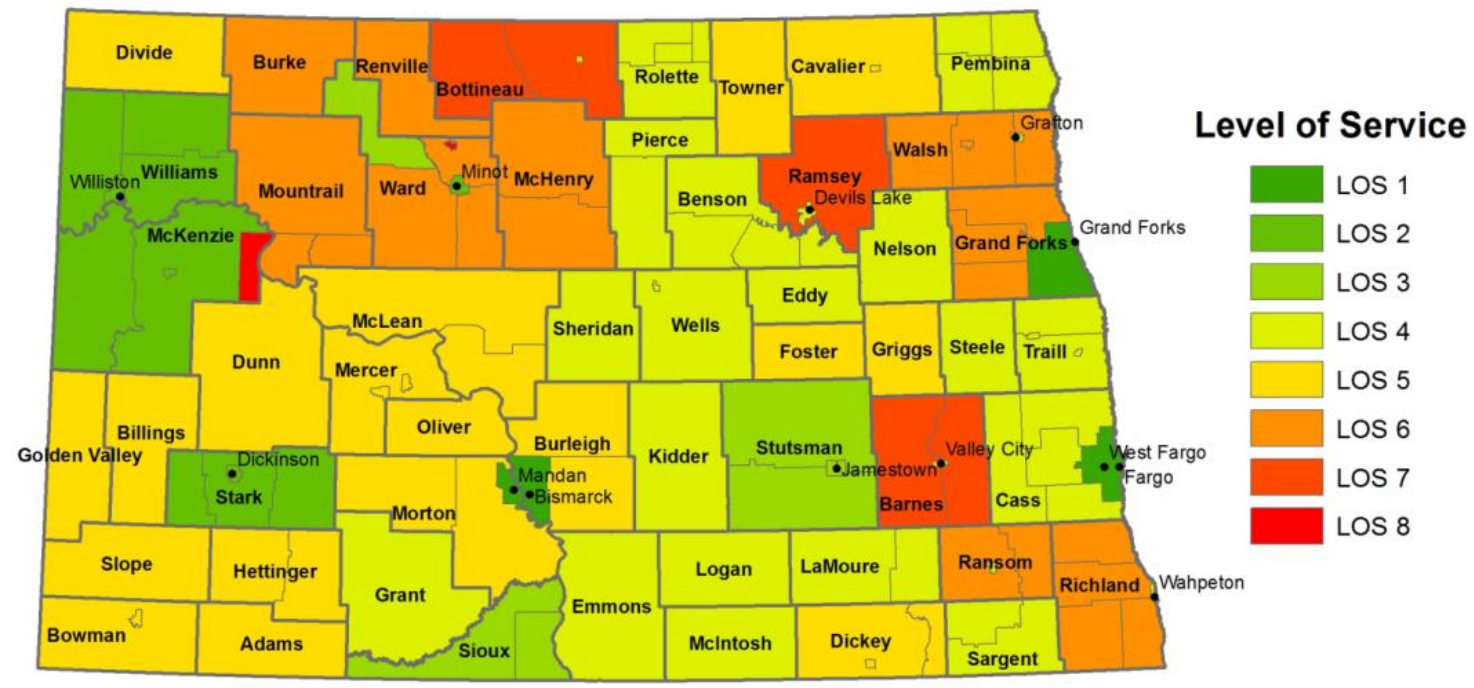

Figure ES1. Demand-Response Transit Level of Service in North Dakota, All Types of Services 


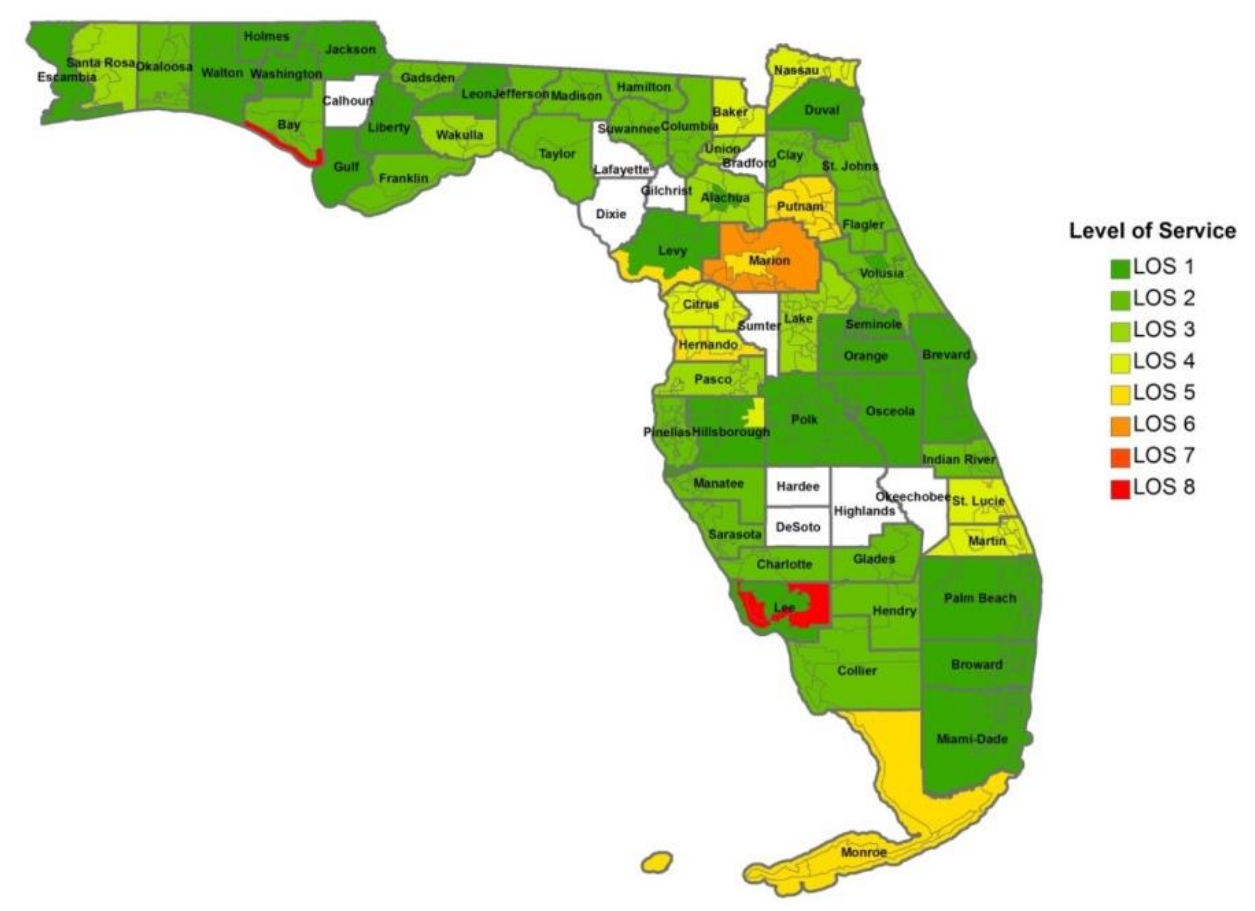

Figure ES2. Demand-Response Transit Level of Service in Florida, All Types of Services As a caveat, the levels of service values calculated in this report were based on the accuracy of the transit agency service details provided by the survey respondents and available from their websites. Data are missing for some agencies that did not response, and service areas or hours for some agencies may have changed by the time this report is published, so the data and results available from this report should be used as a baseline but not for making decisions until proper validation. The point of the exercise it to demonstrate how the collected data could be useful to transportation planners.

\section{Identifying Unmet Needs and Prioritizing Service Improvements}

While level of service values and service coverage data provide valuable information about the extent of DRT service, these measures do not completely identify if the mobility needs of transitdependent populations are being met, nor do they identify the areas with the greatest needs for service improvements. This study proposes a method for combining the service data collected through the survey with population and demographic data to prioritize areas for service improvements.

Population and demographic data provide guidance for determining where the greatest needs for mobility services exist. This study uses a mobility needs index based on three factors deemed important for determining mobility needs: population aged 65 or older, population with a disability, and population below the poverty line. The process ranks all regions on a scale of 1 to 5 , with higher values identifying areas with greater mobility needs. The mobility needs index is used as a proxy for identifying areas with greater needs for demand-response services, but it does not suggest that needs are unmet. 
Comparing the mobility needs index with the existing level of service provides information about where the greatest needs exist for service improvements. This study developed a method of combining these two sources of information to rank areas in terms of needed improvements. The procedure ranks areas on a 1-10 scale in terms of needed improvements (with a rank of 1 indicating greatest need). Areas with a lower level of existing services or a higher mobility needs index were given a higher priority ranking. Resulting priority rankings for North Dakota and Florida are shown in Figures 3 and 4. The ranking is somewhat subjective and can be modified according to the priorities in any given state. The procedure shows how the level of service data collected in this study can be combined with population and demographic data to identify areas with the greatest needs for DRT service improvements. This information can help transit agencies, metropolitan planning organizations, and state departments of transportation make investment decisions.

This is one method for prioritizing investment needs that should be considered in conjunction with other sources such as existing NTD data and public input. Other data collected in the survey, such as service type, service eligibility, and minimum advance reservation time should also be considered when analyzing current services.

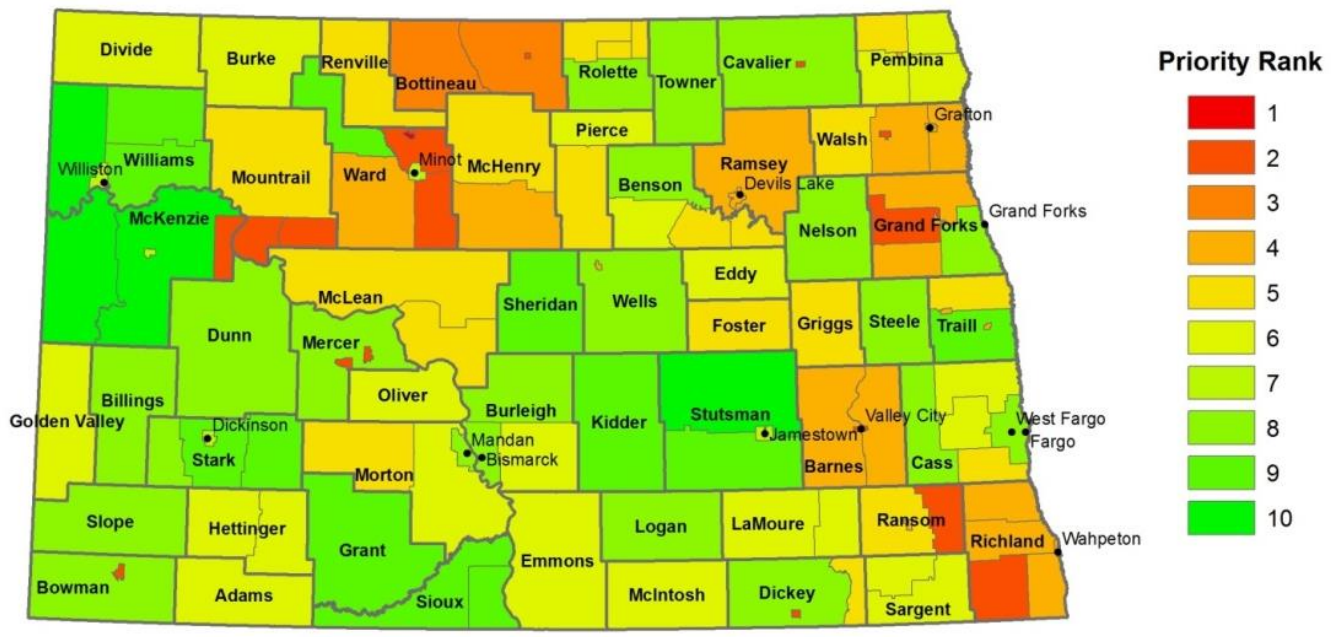

Figure ES3. Priority Ranking for Receiving Demand-Response Service Improvements in North Dakota, Based on Service Span and Expected Need 


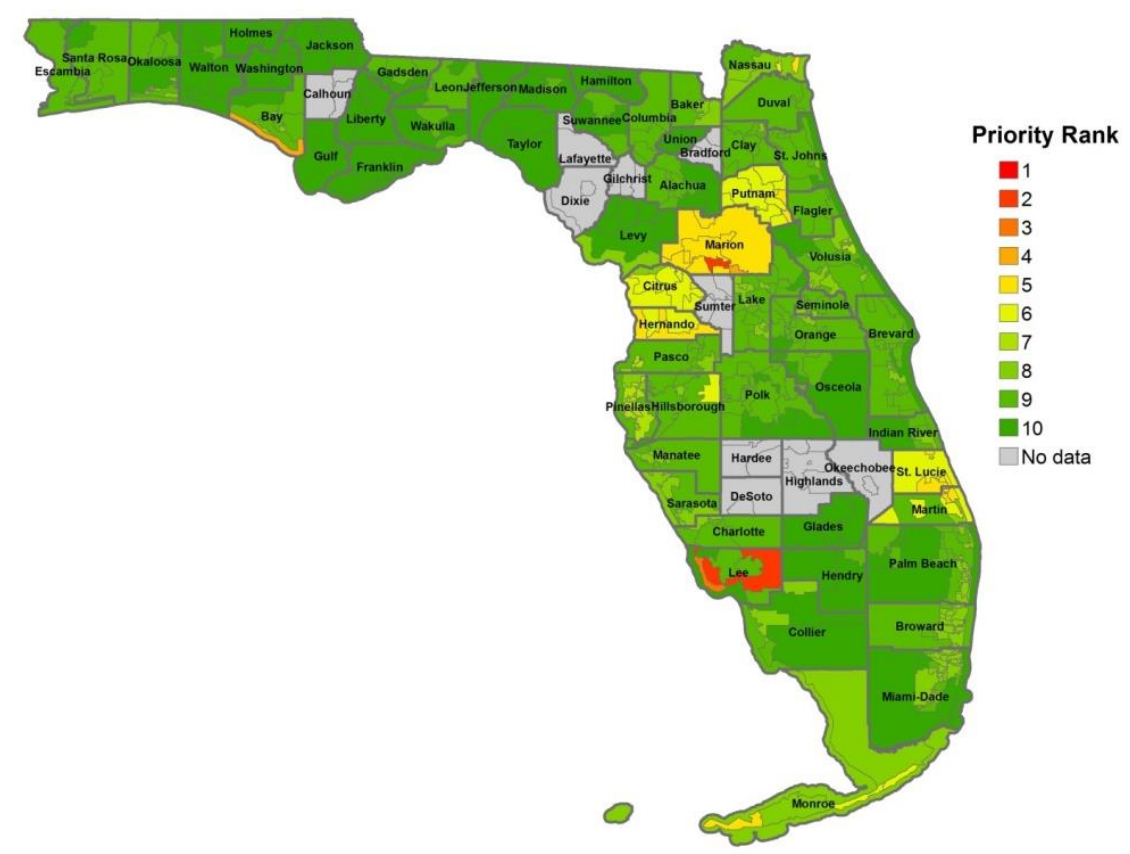

Figure ES4. Priority Ranking for Receiving Demand-Response Service Improvements in Florida, Based on Service Span and Expected Need

\section{Recommendations}

This study recommends using the survey instrument conducted for the Florida survey. As indicated by responses from the survey of Florida agencies, the reporting burden for transit agencies to provide this information is not too great. The collected level of service data can then be mapped and compared to American Community Survey data by associating the cities and rural areas with census tracts.

DRT service details such as service span, service area, service type, and service eligibility are critical for determining the level of DRT service that is being provided. Therefore, having such data available in the NTD or elsewhere for all transit agencies operating any type of DRT would be helpful for understanding the current levels of service being provided and for identifying areas that should be priorities for service improvements. 


\section{INTRODUCTION}

Demand-response transit (DRT) service is a major source of mobility for older adults and people with disabilities in urban and rural areas. DRT operates based on individual requests or demands for transportation service and responds by providing transportation service using passenger cars, vans, or small buses. These DRT vehicles will pick up and drop off people at desired origins and destinations by providing door-to-door or curb-to-curb service. Curb-to-curb service is similar to conventional taxi service and door-to-door service is where drivers may assist passengers from the transit vehicle to the destination building. Buses used for DRT service are generally equipped with wheelchair lifts to make them accessible for individuals who cannot use the stairs. The DRT system is also known as dial-a-ride, demand-activated transportation, shared-ride paratransit, or flexible-route service. Americans with Disability Act (ADA) paratransit is a type of DRT provided for people with disabilities who cannot use a fixed-route service. In general, DRT may serve the general public or certain rider groups such as seniors, persons with disabilities, transportation-disadvantaged persons, etc. (KFH 2008).

Federal Transit Administration (FTA) grant programs under sections 5307, 5310, and 5311 have components designed to increase the availability of demand-response service. In many rural areas, DRT is the only form of transit available, while urban areas rely on DRT to complement fixed-route services. While DRT is a critical component of a community's transit system, the data needed to assess the level of service being provided is lacking.

The National Transit Database (NTD) is a standard reporting system for urban and rural transit providers and can be used to assess transit system performance. However, there is little information in the NTD or elsewhere about the extent of DRT coverage across the country. Therefore, it is a challenge to identify gaps in service coverage and to understand unmet needs. Transit agencies, metropolitan planning organizations (MPOs), and state departments of transportation (DOTs) planning for demand-response service often lack data on where the greatest needs for additional service coverage exist. Therefore, there is a great need to fill the gaps in the data available from NTD database to effectively assess the DRT level of service.

The general transit feed specification (GTFS) has proven to be very useful for allowing public transit agencies to share service information such as locations of stops and routes, schedules, stop times, headways, etc., making it easier to identify and evaluate the level of service being provided. The development of applications that leverage GTFS data will help with service planning and enhance the understanding of operational activity for the transit agencies (Catala 2011). A research project underway proposes to determine national fixed-route transit coverage using GTFS data (National Center for Transit Research 2012). However, the information in GTFS is specific to fixed-route service and a different method needs to be developed to allow transit agencies nationwide to share key information about their demand-response level of service. 
The objectives of this study are:

\section{Primary Objective:}

Develop a method for assessing national demand-response transit level of service.

\section{Secondary Objectives:}

1) Summarize research on transit level of service and demand-response level of service.

2) Determine the data needs for tabulating the DRT level of service for the study framework.

3) Design the framework of the study for calculating the DRT level of service and understanding the level of service coverage.

4) Design and develop a survey tool for collecting required data.

5) Calculate the DRT level of service for all transit agencies in selected test states and map the level of service to identify needs for service improvements.

6) Provide recommendations to construct a DRT level of service survey tool for any state, and ultimately nationwide, to understand the needs for improvement in the DRT system.

7) Develop a priority ranking concept for communities to prioritize improvements to meet needed service.

The report is organized as follows. Section 2 describes the framework used to determine the DRT level of service coverage in test states. Section 3 discusses the data available from the NTD and its applicability in the study framework. It also describes the need for additional data not available from the NTD. Survey tools were developed to collect these data. These surveys were conducted in two test states: North Dakota and Florida. Sections 4 and 5 detail the survey development, administration, and results for North Dakota and Florida, respectively. Section 6 illustrates the framework used for prioritizing needs for service improvements which was applied to the survey data collected from North Dakota and Florida. Finally, conclusions and recommendations are provided in Section 7. 


\section{FRAMEWORK OF THE STUDY}

The primary objective of this study is to develop a framework for identifying DRT level of service across the country. This framework was then tested in two pilot states: North Dakota and Florida. These two states were chosen because they provide a mix of geographic types. North Dakota is largely rural with some small urban areas, while Florida has large urban and suburban areas, along with smaller urban and rural areas. Testing the framework in areas with a mix of geographic types could ensure that the effort would be successful if applied nationwide.

Any additional data required for determining the level of service, beyond the data available from NTD, would be gathered by surveying DRT agencies operating in these two states. Based on an analysis of NTD data and the results from the data collection efforts in the two test states, recommendations and suggestions can be provided regarding data needs and data collection techniques.

The framework for evaluating level of service for demand-response transit was adapted from the second and third editions of the Transit Capacity and Quality of Service Manual (TCQSM) (Kittelson \& Associates, Inc. 2003, 2013). The TCQSM defines the quality of service for demand-response transit service based on various parameters such as response time, service span, reliability, on-time performance, trips not served, and travel time of demand-response transit (Kittelson \& Associates, Inc. 2013).

The second edition of the TCQSM developed a framework for determining the quality of service (QOS) for DRT which is intended to be used for general public and limited-eligibility DRT services (Kittelson \& Associates, Inc. 2003). The third edition of this manual simplified the framework for determining the QOS for DRT; however the framework is not intended for QOS measurement of ADA paratransit (Kittelson \& Associates, Inc. 2013). Our study, though, includes ADA paratransit and all forms of demand-response transit services. See Appendix A for more information about ADA paratransit.

The TCQSM categorizes quality-of-service measures into two types: those describing the availability of the service and those related to comfort and convenience. For availability, the quality of the DRT service can be determined based on response time, service span, and service coverage. For comfort and convenience, quality of service can be determined based on reliability, travel time, and no-shows (Kittelson \& Associates, Inc. 2003). This study focuses on determining the quality of service based on availability of service, not comfort and convenience.

Service span measures the days per week and hours per day that service is available in a particular area, and it is a key measure of service availability and quality of service. The TCQSM second edition devised a measure of demand-response transit level of service based on days and hours of service, as shown in Table 2.1 (Kittelson \& Associates et al. 2003). The lower number indicates a higher level of service, with LOS 1 being the highest level of service. 
Table 2.1 Level of Service Measures for Demand-Response Service Based on Service Span

\begin{tabular}{cccccccc}
\hline $\begin{array}{c}\text { Hours Per } \\
\text { Day }\end{array}$ & $6-7$ & 5 & $3-4$ & 2 & 1 & $0.5^{*}$ & $<0.5$ \\
\hline$\geq 16.0$ & LOS 1 & LOS 2 & LOS 4 & LOS 5 & LOS 6 & LOS 7 & LOS 8 \\
$12.0-15.9$ & LOS 2 & LOS 3 & LOS 4 & LOS 5 & LOS 6 & LOS 7 & LOS 8 \\
$9.0-11.9$ & LOS 3 & LOS 4 & LOS 4 & LOS 6 & LOS 6 & LOS 7 & LOS 8 \\
$5.0-8.9$ & LOS 5 & LOS 5 & LOS 5 & LOS 6 & LOS 7 & LOS 7 & LOS 8 \\
$<5^{* *}$ & LOS 6 & LOS 6 & LOS 6 & LOS 7 & LOS 7 & LOS 8 & LOS 8 \\
\hline
\end{tabular}

*Service twice per month

** The TCQSM second edition uses " $<4$ hours" as the lowest level for hours of service, but this was revised to " $<5$ hours" in the third edition, which is what is used in this study. The TCQSM third edition no longer combines days and hours of service into a single level of service measure.

Source: TCQSM, $2^{\text {nd }}$ Edition \& $3^{\text {rd }}$ Edition

This study uses service span as a key part of the method for identifying DRT level of service, adopting the framework shown in Table 2.1. Further, the method calls for service-span data to be integrated with service location to better understand the DRT service coverage. The level-ofservice data can then be mapped to show areas with higher or lower levels of service. Mapping the DRT level of service for each transit agency in a state would provide valuable information regarding service area and level of service throughout the state and it could be used to better understand where service improvements are necessary.

Apart from determining the level of service of DRT based on service span, the level of service based on response time (advanced reservation time) can also be calculated following the procedure from the second edition of the TCQSM as shown in Table 2.2.

Table 2.2 Level of Service Measure for Demand-Response Transit Service Based on Response Time

\begin{tabular}{lc}
\hline Response Time & $\begin{array}{c}\text { Level of } \\
\text { Service } \\
\text { (LOS) }\end{array}$ \\
\hline Up to $1 / 2$ hour & 1 \\
More than $1 / 2$ hour, and up to 2 hours & 2 \\
More than 2 hours, but still same day & 3 \\
24 hours in advance, or prior service day & 4 \\
48 hours, or 2 days, in advance & 5 \\
More than 48 hours in advance, and up to 1 week & 6 \\
More than 1 week in advance, and up to 2 weeks & 7 \\
More than 2 weeks & 8 \\
\hline
\end{tabular}

Source: TCQOS Manual, $2^{\text {nd }}$ Edition 
It must be understood that the level of service determined from the advance reservation time is different from level of service determined from the service span. Level of service determined based on service span is the main objective of this study and in-depth analysis and graphs appear towards the end of the report. Level-of-service values based on advance reservation time are provided to enhance the understanding of the effectiveness of transit agencies' services from an advance reservation time perspective. 


\section{DATA AVAILABILITY AND DATA NEEDS}

The National Transit Database (NTD) is the primary source for information and statistics on transit systems in United States. Transit agencies receiving section 5307 Urbanized Area Formula Program funding or section 5311 Non-Urbanized Area Formula Program funding are required to report data to the NTD. The reporting requirements differ between urban and rural agencies, with rural providers generally required to report less data.

For DRT agencies, NTD service data are available for vehicle revenue hours, vehicle revenue miles, unlinked passenger trips, operating expenses, and safety and security events. These data are helpful for calculating performance measures such as passenger trips per revenue hour or mile, operating cost per revenue hour or mile, operating cost per passenger trip, and safety incidents per 100,000 vehicle miles, which are some of the commonly analyzed performance measures (KFH Group et al. 2008, Godavarthy et al. 2014, Ellis 2009).

The NTD data are somewhat limited, however, in their ability to capture quality of service. KFH Group et al. (2008) suggested that beyond the data that is available from NTD, other data such as on-time trips, requested trips, reserved trips, scheduled trips, completed trips, cancellations, noshows, missed trips, trip denials, trip length, and travel time can be useful for determining additional DRT performance measures such as no-show/late cancellation rate, cancellation rate, missed-trip rate, trip denial rate, compliant rate, average passenger trip length, and average travel time for better assessing the DRT service. Furthermore, a study conducted by GAO examined the NTD for the availability of ADA paratransit trips and ADA expenses and identified that onethird of the transit agencies have not reported this data (GAO 2012). The study has concluded that timely and accurate NTD data would help Congress and FTA allocate funding to improve public transportation in the nation (GAO 2012).

While many studies and reports document various measures to determine the performance of a DRT service (KFH Group et al. 2008, GAO 2012, Kittelson \& Associates et al. 2003, Godavarthy Et al. 2015), there are not many studies available to determine the extent of demandresponse service coverage in the United States due to the lack of primary data in the NTD

Key variables for identifying the level of DRT service across the country include geographic coverage, days of service per week, hours of service per day, advance reservation requirements, and service eligibility. These data are largely missing from the NTD. Service span, one of the measures of quality of service used in the TCQSM, and geographic coverage are two variables that are especially important but which have limited data availability. While the NTD has data for service span for some of transit agencies, service span data for DRT service is not available for any agency in the rural NTD.

With regard to geographic coverage data (geographic area served by DRT transit agencies), very general service area (city, or counties served) information is available for some transit agencies in the NTD, but the data available are not specific or precise, and are therefore inadequate for the study methodology. In the rural NTD, agencies are asked to identify the county or counties in which they provide service. Some of the multi-county providers do not list all of their counties, so the data are incomplete. The data are also imprecise because an agency might not provide service within some areas of the county, or the level of service provided may differ within the 
county. Some areas might receive daily service, while others have service twice a week. Geographic coverage and level of service information at a level finer than the county, such as municipalities, zip codes, census block groups, census tracts, etc., would be helpful. This level of information is not available through the NTD.

Further, the availability of additional service data for DRT agencies such as minimum advance reservation time, service eligibility, and type of DRT service provided (curb-to-curb, door-todoor, etc.) would be helpful for identifying the type and level of service being provided. These data also are not available from the NTD. A significant limitation of the NTD is that it does not distinguish ADA paratransit from general public DRT and other forms of demand-response services.

It was concluded that, although the NTD and rural NTD data have a significant level of DRT service data, it is not sufficient for determining the level of service and service coverage for DRT service across the country. Therefore, based on the study framework and the analysis of NTD data, there is a need for additional service details from transit agencies providing DRT service. As the long-term vision from this project would likely be to expand and understand the level of service coverage of DRT service nationwide, uniform, complete, and accurate data would be needed from the NTD or another data source.

To collect the necessary data, a new survey tool needs to be developed that can administered nationwide. To that end, this study developed two versions of a survey tool and tested them with transit agencies in North Dakota and Florida. More details regarding these surveys can be found in the following sections. 


\section{TEST SURVEY OF NORTH DAKOTA TRANSIT AGENCIES}

\subsection{Developing and Administering the Survey}

An online survey tool was prepared by the research team and was distributed in August 2014 to all transit agencies providing DRT service in the state of North Dakota. The intent of the survey was to gather information on service eligibility, service span, service area, service type, minimum advance reservation time, and trips turned down. In developing the survey, consideration was given to balancing the need for collecting detailed data versus minimizing the burden to transit agencies. If the survey was too complicated and detailed, the response rate may be low and the data collected may be incomplete or inaccurate. On the other hand, the survey needed to collect enough detailed data to be useful and achieve the objectives of the study.

A map tool was developed and used in the survey to collect information regarding service area and span of service. More details about this tool are provided in Section 4.2. For ADA complementary paratransit, service area is often defined in terms of its relation to fixed-route service. The ADA requires that complementary paratransit be provided within $3 / 4$ mile of all fixed-routes, but transit agencies may provide a higher level of service that goes beyond this requirement. To capture information about service coverage for ADA paratransit, an additional survey question asked providers of this type of service to describe their ADA paratransit service area, with the following options: operate within $3 / 4$ mile of fixed-route, operate within some other distance of fixed-route (please indicate distance), or other (please describe service area).

Appendix B shows the online survey that was distributed to DRT agencies in North Dakota, and Appendix $\mathrm{C}$ describes the framework that was used for developing the survey and map tools. The survey also included a few additional questions that were used for an additional study and are not reported here. The full survey and results can be found in Mattson and Hough (2015).

The survey was distributed to 33 transit agencies in North Dakota identified by the North Dakota Department of Transportation (NDDOT). Responses were received from 27 of these transit agencies, yielding a response rate of $82 \%$. The high response rate was because NDDOT encouraged transit agencies to take the survey by sending e-mails apart from the reminders sent by the research team. A complete list of transit agencies is shown in Table 4.1, along with information on areas served and whether the agency completed the survey. The DRT service details for the transit agencies that did not respond to the survey were obtained from the agency's website and the results were summarized to be used for calculating the level of service values. 
Table 4.1 Transit Agencies in North Dakota

\begin{tabular}{|c|c|c|}
\hline Transit Agency & Area Served & $\begin{array}{l}\text { Completed } \\
\text { survey }\end{array}$ \\
\hline Benson County Transportation & Benson, Wells, Pierce, and Ramsey Counties & Yes \\
\hline Bis-Man Transit Board & Cities of Bismarck, Mandan, and Lincoln & Yes \\
\hline Cando Transportation & Towner County & No \\
\hline Cavalier County Transit & Cavalier County & Yes \\
\hline Devils Lake Transit /Eddy Co Transit & Ramsey and Eddy Counties & Yes \\
\hline Dickey County Transportation & Dickey County & Yes \\
\hline Dickinson Public Transit (Elder Care) & Stark, Morton, and Burleigh Counties & Yes \\
\hline Fargo Metro Area Transit & Cities of Fargo and West Fargo & Yes \\
\hline Glen Ullin City Transportation & Morton County & Yes \\
\hline $\begin{array}{l}\text { Golden Valley/Billings Cncl. On } \\
\text { Aging }\end{array}$ & Golden Valley and Billings Counties & No \\
\hline Grand Forks - Cities Area Transit & City of Grand Forks & Yes \\
\hline Handi-Wheels Transportation & Cities of Fargo and West Fargo & Yes \\
\hline Hazen Busing & Mercer and Oliver Counties & Yes \\
\hline James River Public Transit & Stutsman, Wells, and Sheridan Counties & Yes \\
\hline Jamestown, City of & City of Jamestown & No \\
\hline Kenmare Wheels \& Meals, Inc. & City of Kenmare & Yes \\
\hline Kidder/Emmons Senior Services & Kidder County & Yes \\
\hline Minot, City of & City of Minot & Yes \\
\hline Nelson County Transportation & Nelson and rural Grand Forks Counties & Yes \\
\hline Northwest Dakota Public Transit & Divide, Williams, and McKenzie Counties & Yes \\
\hline Nutrition United/Rolette Co. Transp. & Rolette County & No \\
\hline Pembina County Meals \& Trans & Pembina County & Yes \\
\hline Souris Basin Transportation & $\begin{array}{l}\text { Burke, Renville, Mountrail, Ward, Bottineau, Pierce, and } \\
\text { McHenry Counties }\end{array}$ & Yes \\
\hline South Central Adult Servcies & $\begin{array}{l}\text { Barnes, LaMoure, Foster, Logan, McIntosh, Griggs, Emmons, } \\
\text { Stutsman, and Cass Counties }\end{array}$ & Yes \\
\hline Southwest Transportation Services & Adams, Bowman, Hettinger, and Slope Counties & Yes \\
\hline Spirit Lake Transit & Benson County and Devils Lake & Yes \\
\hline Standing Rock Public Transportation & Sioux, Morton, and Burleigh Counties & Yes \\
\hline Trenton Indian Services Area & Williams County & No \\
\hline Turtle Mountain Transit & Rolette County & No \\
\hline Valley Senior Services & $\begin{array}{l}\text { Cass, Traill, Steele, Richland, Ransom, Sargent and Grand Forks } \\
\text { Counties }\end{array}$ & Yes \\
\hline Walsh County Transportation & Walsh, Pembina, and Grand Forks Counties & Yes \\
\hline West River Transit & $\begin{array}{l}\text { Burleigh, Morton, Oliver, Mercer, McLean, Dunn, and Grant } \\
\text { Counties }\end{array}$ & Yes \\
\hline Wildrose Senior Transportation & Williams and Divide Counties & Yes \\
\hline
\end{tabular}

\subsection{Map Tool Used for the Study}

The survey used a map tool for the respondents to select areas where their agency provides DRT service. The map tool was used because it may be easier and quicker for transit agencies to identify and select their service areas on a map than to provide this information in some other way. Geographic areas depicted on the map could also correspond to data from the U.S. Census or American Community Survey (ACS) so that transit service data could be compared to population and demographic data. For example, if the survey tool used areas based on census tracts or zip codes, the end result would be census tract or zip-code-level data regarding transit service details, which could then be combined with census tract or zip-code-level population and demographic data from the Census and ACS. This level of detail would allow transit planners and decision-makers to compare existing transit service levels with the need for these services, based on population data. 
The geographic areas used in the survey map, therefore, would have to be areas for which data are available from the ACS, which could include counties, census tracts, census block groups, or zip codes. The intent was to collect data at a finer detail than the county level, but collecting data at too fine of detail would be unnecessary and would create too much of a burden for transit agencies. The research team first considered using zip code areas for the map, but preliminary test surveys suggested that zip code level categorization might result in a very low response rate, as many of the agencies operate based on county borders (zip codes do not follow county borders). Further, zip code areas are rather small, and many transit agencies, especially those serving large, multi-county areas, provide service to many different zip codes. Therefore, it was determined that it would be too much of a burden to ask rural transit operators to locate and identify all of the zip codes they serve. Instead, census tracts were chosen because in the rural areas of North Dakota, census tracts are much larger than zip code areas. Many counties in the state have only one, two, or three census tracts. In urban areas, on the other hand, census tracts are too small for the study purposes. Consequently, for cities or metropolitan areas, all census tracts were combined to form a single geographic area. Figure 4.1 compares the North Dakota state map with census tract areas and zip code areas. The map with census tract areas was used in the survey. Respondents were asked to click on the areas they serve, and those areas would then become highlighted.

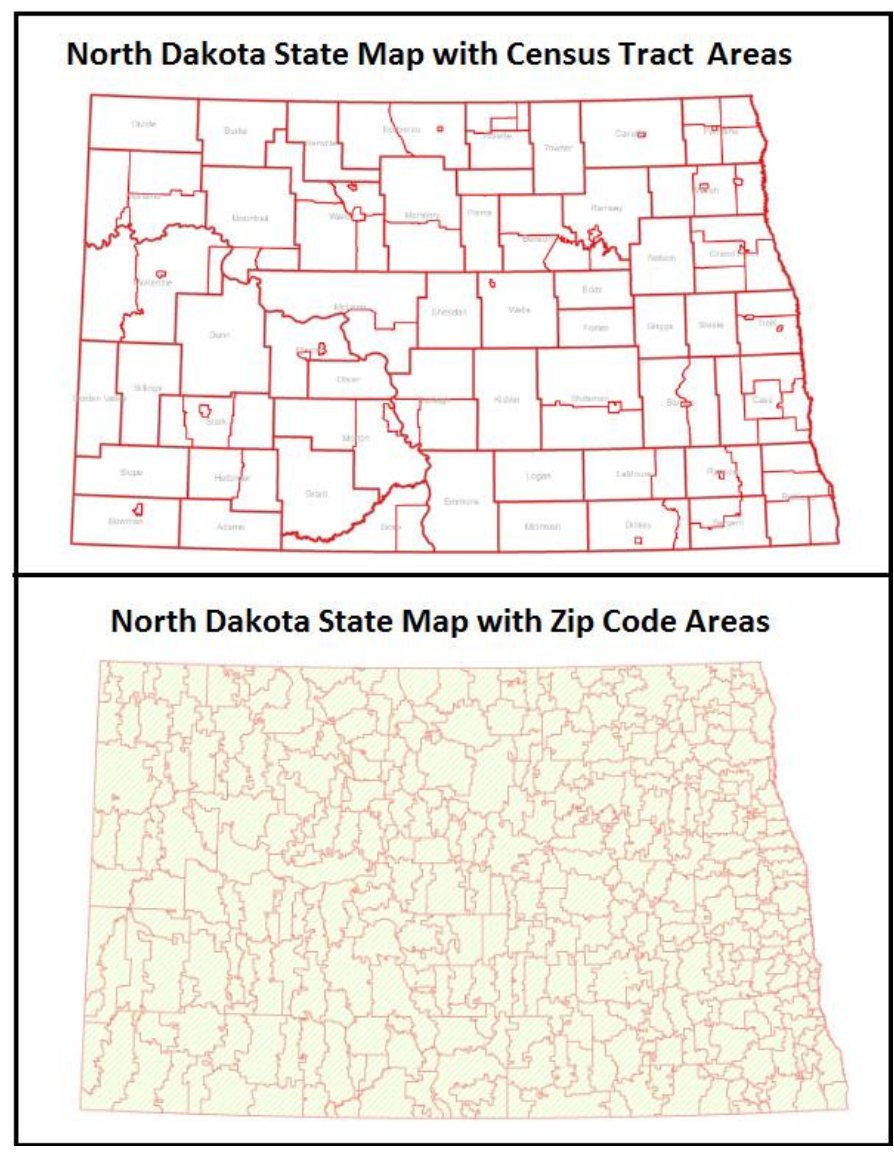

Figure 4.1 North Dakota State Map with Census Tract Areas vs. Zip Code Areas 
The survey collected information on the number of days per week transit agencies provide some kind of DRT service in different areas, as well as the number of hours per service day. If an agency provided different levels of service, such that some parts of their service area received a certain number of hours or days of service and another part of their service area received a different number of hours or days of service, then the respondent was asked to identify the areas where their agency provides different levels of service. Doing so required respondents to complete more than one map. For example, if an agency provided five days of service in one part of their service area and two days of service in the remainder of their service area, the respondent would be required to complete two maps. The first would be used to identify areas where the agency provides service five days per week, and the second would identify where the agency provides service twice a week. If service hours also differed, respondents would be required to complete additional maps to convey this information.

\subsection{Survey Results Summary}

\subsubsection{Type of Service Provided}

Most of the transit agencies in North Dakota (23 out of 27) provide DRT service for the general public. Table 4.2 summarizes the types of service provided by all the transit agencies in North Dakota. Most of the transit agencies provide door-to-door service (Table 4.3).

Table 4.2 What type of transportation services does your organization provide (check all that apply)?

\begin{tabular}{lcc}
\hline Service Type & $\begin{array}{c}\text { Number of } \\
\text { Agencies }\end{array}$ & $\begin{array}{c}\text { Percentage of } \\
\text { Respondents }\end{array}$ \\
\hline Traditional fixed route & 4 & $15 \%$ \\
Flexible route & 5 & $19 \%$ \\
Demand-response for the general public & 23 & $85 \%$ \\
Limited-eligibility demand-response (serving only certain rider groups) & 1 & $4 \%$ \\
Human service transportation (for clients of human service programs) & 11 & $41 \%$ \\
Veteran transportation & 10 & $37 \%$ \\
\end{tabular}

Table 4.3 Do you provide the following types of service (check all that apply)?

\begin{tabular}{lcc}
\hline Service Type & $\begin{array}{c}\text { Number of } \\
\text { Agencies }\end{array}$ & $\begin{array}{c}\text { Percentage of } \\
\text { Respondents }\end{array}$ \\
\hline Fixed-route & 5 & $19 \%$ \\
Curb-to-curb & 9 & $35 \%$ \\
Door-to-door & 21 & $81 \%$ \\
Door-through-door or escort service & 0 & $0 \%$ \\
\hline
\end{tabular}

\subsubsection{Service Span and Coverage}

Days and hours of service for all types of DRT services are mapped in Figures 4.2 and 4.3. While everyday service exists in some parts of the state, much of the state has service five days per week. Some areas, such as some north central or northwest parts of the state, have service just one day per week. A few areas have service two or three days per week. Fixed-route services 
in Fargo-West Fargo, Bismarck-Mandan, and Grand Forks operate six days per week, while the complementary paratransit is available seven days per week in Fargo-West Fargo and BismarckMandan and six days per week in Grand Forks. Dickinson Public Transit provides service seven days per week in Stark County, but trips outside the city of Dickinson are limited pending driver availability. The rural transit agencies most commonly provide service 8-10 hours per day, while a few areas have a more limited service. The urban transit agencies provide service 16 or more hours per day, and Dickinson Public Transit provides about 15 hours per day.

Using the number of days DRT service is provided and number of hours of service per day, the level of DRT service in these census tract areas was calculated using the methodology described in Section 2. Based on this framework, level of service for DRT service was calculated and mapped across the state (Figure 4.4).

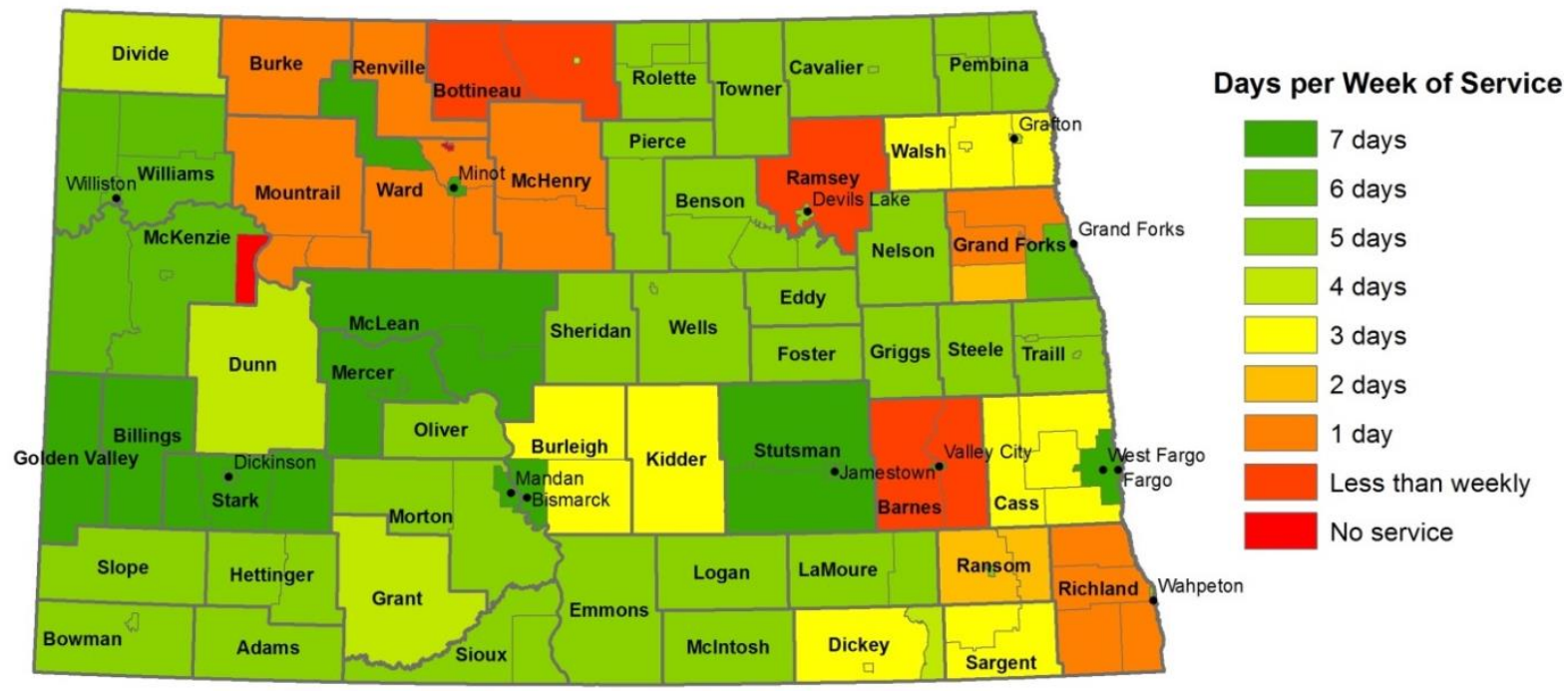

Figure 4.2 Days per Week of Demand-Response Transit Service in North Dakota

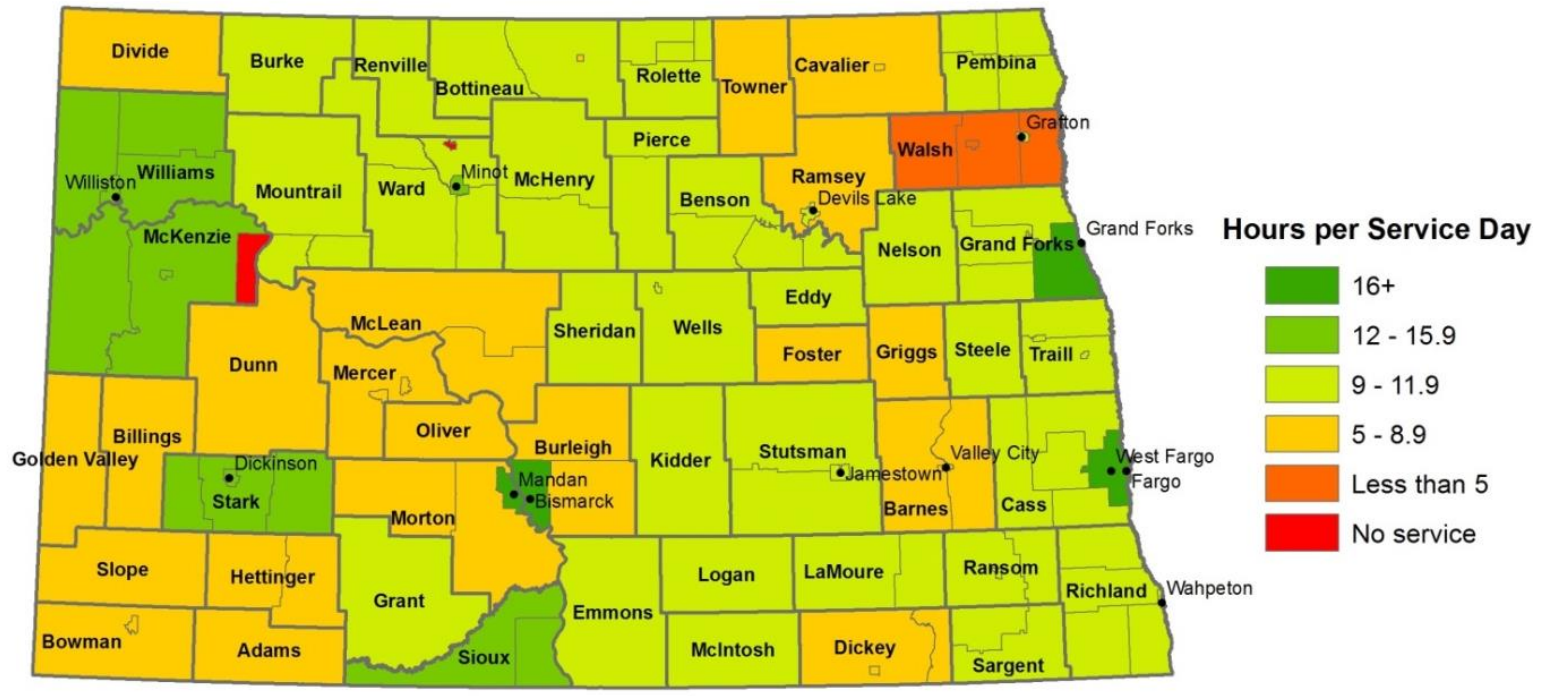

Figure 4.3 Hours per Service Day for Demand-Response Transit Service in North Dakota 


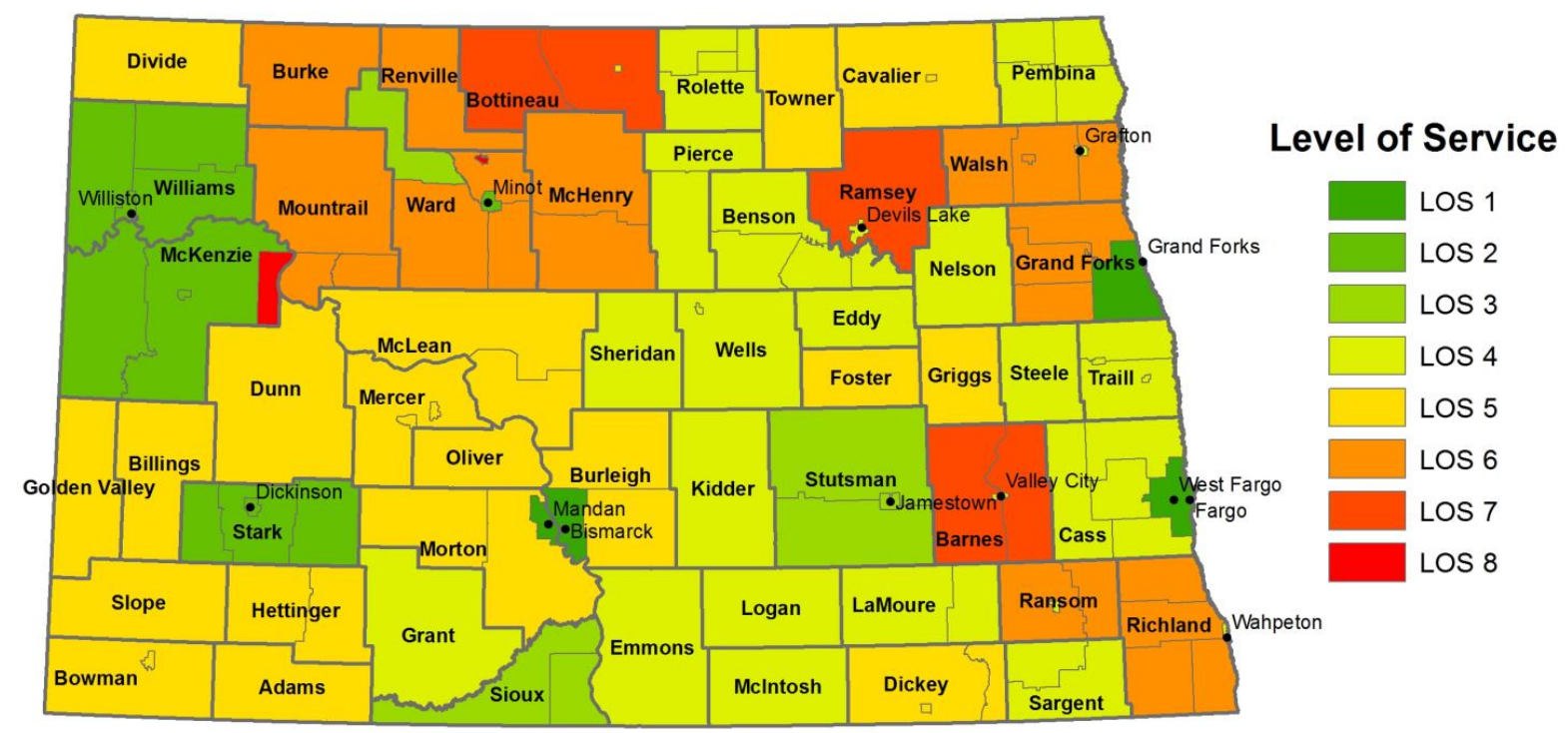

Figure 4.4 Demand-Response Transit Level of Service in North Dakota

Level of service is highest in the urban areas of Fargo, Bismarck, and Grand Forks. Stark and Kidder counties have the next-highest levels of service, as measured by service span. The cities of Minot and Kenmare in Ward County have good levels of service, but the rest of the county has lower levels of service. Similarly, Valley City, Lisbon, Wahpeton, Devils Lake, Grafton, Bottineau, Williston, and Watford City have decent levels of service, usually five days per week, but the rural areas of their counties have lower levels of service.

The ADA paratransit providers in North Dakota all go beyond the minimum requirements for service area and span of service. Cities Area Transit, the Bis-Man Transit Board, and MATBUS provide complementary paratransit within the cities limits of Grand Forks, Bismarck, Mandan, Fargo, and West Fargo, covering the entire cities. Souris Basin Transportation provides complementary paratransit service throughout the city of Minot.

Span of service is also greater than ADA requirements for the complementary paratransit in some cities. The Bis-Man Transit Board paratransit service runs 24/7. MATBUS provides paratransit service 7 days a week in Fargo and West Fargo, while the fixed-route service runs 6 days a week in those cities. In Minot, the fixed-route service runs 5 days a week, while the paratransit service is available 7 days a week.

\subsubsection{Advance Reservation Time}

Response time, or advance reservation time, is an important measure of transit availability. Allowing riders to schedule trips with shorter advance notice increases the availability of the service to the user. The TCQSM includes reservation time as a measure of DRT quality of service (Kittelson \& Associates, Inc. 2003). In the survey with North Dakota DRT agencies, respondents were asked to identify their agency's minimum advance reservation time for DRT, using categories from the TCQSM second edition. 
As shown in Table 4.4, transit agencies commonly require reservations to be made 24 hours in advance, or during the previous service day, but more than half allow for reservations to be made the same day as the trip, including nine agencies that provide trips within one half hour of making the reservation. Some operators provide this high-quality service for in-town trips but require more advanced notice for out-of-town trips. For example, Cavalier County Transit, Southwest Public Transit, and South Central Adult Service allow in-town trips to be made with a half-hour reservation time, but out-of-town trips need to be scheduled the previous service day.

Table 4.4 What is the minimum advance reservation time for your agency operating demand-response or complementary paratransit?

\begin{tabular}{lcc}
\hline Minimum Advance Reservation Time & $\begin{array}{c}\text { Percentage } \\
\text { of }\end{array}$ \\
Up to 1/2 hour & $\begin{array}{c}\text { Number of } \\
\text { Agencies }\end{array}$ & $\begin{array}{c}\text { Respondents } \\
\text { More than 1/2 hour and up to 2 hours }\end{array}$ \\
More than 2 hours, but still same day & 3 & $35 \%$ \\
24 hours in advance, or prior service day & 3 & $12 \%$ \\
48 hours, or 2 days, in advance & 11 & $42 \%$ \\
More than 48 hours in advance, and up to 1 week & 0 & $0 \%$ \\
More than 1 week in advance, and up to 2 weeks & 0 & $0 \%$ \\
More than 2 weeks & 0 & $0 \%$ \\
\hline
\end{tabular}

\subsection{Evaluation of Survey}

The survey of North Dakota transit agencies was mostly successful. The high, $82 \%$ response rate was influenced by the NDDOT, which had an interest in receiving responses to the survey. The agency requested transit agencies via email to take the survey, in addition to the reminders sent by the research team.

Most respondents did not have a problem answering the question with the map (question \#8, refer to Appendix B), where the regions with DRT service needed to be selected. There were two respondents, however, who could not answer the map question as their computer could not support the program/tool used in the survey for the map. Another respondent found the survey to be difficult or confusing and contacted a member of research team by phone. Information from this respondent was collected over the phone.

One issue identified was that some small census tracts were missed (not selected in the map tool) by the survey respondents. Some of the larger towns have their own census tract, while the rest of the county is divided into one or more larger tracts. For example, Richland County is divided into four large tracts and one small tract for the city of Wahpeton; Ransom County is divided into two large tracts and one small tract for the city of Lisbon; etc. In some cases, the respondent from the transit agency would not click on these smaller census tracts even though their agency provides service in that city. Respondents would click on the larger, rural areas but miss the tract for the individual city. The research team was able to identify and correct these errors for the state of North Dakota, but implementing the survey map tool on a wider scale will require an instrument that will be less prone to error. 
Another issue with the method used in the North Dakota survey is that it may prove difficult to transfer to other states. Census tracts may work in a sparsely populated state such as North Dakota because the tracts are fairly large and usually easy to identify on a map. However, in more densely populated states, census tracts are much smaller and more numerous. As a result, transit agencies would have to select many more areas, increasing respondent burden and the possibility of error. Furthermore, that level of detail is not necessary.

For these reasons, the research team decided to test a different approach for the Florida survey. Options other than census tracts were considered for the map tool, but none would have been ideal for potential nationwide adoption. Therefore, the map tool was not used in the Florida survey. The alternative approach used will be described in Section 5. 


\section{TEST SURVEY OF FLORIDA TRANSIT AGENCIES}

\subsection{Developing and Administering the Survey}

An online survey tool was prepared using Qualtrics software to gather the data required for levelof-service calculations from all DRT agencies in the state of Florida. Similar to the survey conducted in North Dakota, this survey gathered details about service eligibility, service span, service area, service type, and minimum advance reservation time. However, the approach for determining geographic service areas differed from that used in the North Dakota survey. Instead of using a map to identify service area, transit agencies were simply asked to identify counties and cities in which they provide service and the days and hours of service in each.

Appendix D shows the online survey that was distributed to transit providers in Florida. Transit agencies were first asked to identify counties in which the agency provides demand-response service. Then for the individual county or counties selected, the survey asked if the agency provides the same days and hours of service throughout the county or if they provide different levels of service in the county or do not serve some areas of the county. If service is the same throughout the county, the survey asked agencies to identify the number of days and hours of service provided in the county. If service differs, the survey then listed each city in the county and asked respondents to identify the number of days and hours of service for each city. Rural areas of the county not belonging to any city were also included in the survey and referred to as "other rural areas" (refer to Appendix D, which illustrates these two scenarios).

The survey was distributed via Florida Community Transportation Coordinators, the Florida RTAP listserv, and contacts from the Florida Public Transportation Association. In addition, transit agencies, as identified in the NTD, were contacted individually if they had not yet responded.

The survey was distributed in February 2015, and transit agencies who had not responded in February were contacted with reminder e-mails until May 2015. Among a total of 56 transit agencies identified in Florida according to the NTD, responses were received from 38 agencies providing some kind of DRT service. In addition, service details for seven more DRT transit agencies were extracted from the agency's website or by phone. Some of the 56 transit agencies identified in the NTD did not respond to the survey because they operate exclusively rail transit or fixed-route transit. A complete list of transit agencies is shown in Tables 5.1, along with information on areas served and whether the agency completed the survey.

A few transit agencies providing DRT service in Florida responded to the survey but are not listed in NTD. The following such agencies were included in the study for calculating the level of service values: Mid Florida Community Services, Hillsborough County Sunshine Line, and Guidance/Care Center. Therefore, DRT service details were available from 48 transit agencies (38 DRT agencies from NTD list that responded to the survey, 7 DRT agencies whose service details were gathered from websites or via phone conversations, 3 DRT agencies who responded to the survey that are not on the NTD list of transit agencies) for calculating the DRT level of service values in Florida. 
Table 5.1 Transit Agencies in Florida

\begin{tabular}{|c|c|c|}
\hline Transit Agency & Area Served & $\begin{array}{l}\text { Completed } \\
\text { Survey }\end{array}$ \\
\hline A \& A Transport & Union County & Yes \\
\hline Baker Council on Aging & Baker County & No \\
\hline $\begin{array}{l}\text { Bay County Transportation Planning } \\
\text { Organization }\end{array}$ & Bay County & Yes \\
\hline Big Bend Transit & $\begin{array}{l}\text { Gadsden, Jefferson, Madison, } \\
\text { and Taylor Counties }\end{array}$ & No \\
\hline $\begin{array}{l}\text { Board of County Commissioners, } \\
\text { Palm Beach County, }\end{array}$ & Palm Beach County & Yes \\
\hline Broward County Transit Division & City of Plantation & Yes \\
\hline $\begin{array}{l}\text { Calhoun County Senior Citizens } \\
\text { Association, Inc. }\end{array}$ & Calhoun County & No \\
\hline Central Florida Commuter Rail & City of Sanford & No \\
\hline $\begin{array}{l}\text { Central Florida Regional } \\
\text { Transportation Authority }\end{array}$ & $\begin{array}{l}\text { Orange, Osceola, and } \\
\text { Seminole Counties }\end{array}$ & Yes \\
\hline Charlotte County Transit Division & Charlotte County & Yes \\
\hline Citrus County Transit & Citrus County & Yes \\
\hline $\begin{array}{l}\text { City of Key West Department of } \\
\text { Transportation }\end{array}$ & Monroe County & No \\
\hline City of Ocala, Florida & Marion County & Yes \\
\hline City of Tallahassee & Leon County & Yes \\
\hline Clay County Council on Aging & Clay County & Yes \\
\hline Collier Area Transit & Collier County & Yes \\
\hline Council on Aging of St. Lucie, Inc. & St. Lucie County & Yes \\
\hline County of Volusia, dba: VOTRAN & Volusia County & Yes \\
\hline Crooms, Inc. & Franklin County & Yes \\
\hline Escambia County Area Transit & Escambia County & Yes \\
\hline Flagler Co. Public Transportation & Flagler County & Yes \\
\hline Gainesville Regional Transit System & Alachua County & Yes \\
\hline Good Wheels, Inc. & $\begin{array}{l}\text { Lee, Glades, and Hendry } \\
\text { Counties }\end{array}$ & No \\
\hline Gulf County ARC & Gulf County & No \\
\hline $\begin{array}{l}\text { Hernando County Board of County } \\
\text { Commissioners }\end{array}$ & City of Brooksville & Yes \\
\hline $\begin{array}{l}\text { Hillsborough Area Regional Transit } \\
\text { Authority }\end{array}$ & City of Tampa & Yes \\
\hline Jackson County Transportation, Inc. & Jackson County & No \\
\hline Jacksonville Transportation Authority & Duval County & Yes \\
\hline
\end{tabular}


Table 5.1 Transit Agencies in Florida (cont.)

\begin{tabular}{|c|c|c|}
\hline Transit Agency & Area Served & $\begin{array}{l}\text { Completed } \\
\text { Survey }\end{array}$ \\
\hline $\begin{array}{l}\text { Lake County Board of County } \\
\text { Commissioners }\end{array}$ & Lake County & Yes \\
\hline Lakeland Area Mass Transit District & City of Lakeland & Yes \\
\hline Lee County Transit & Lee County & Yes \\
\hline $\begin{array}{l}\text { Levy County Board of County } \\
\text { Commissioners }\end{array}$ & Levy County & Yes \\
\hline $\begin{array}{l}\text { Liberty County Board of County } \\
\text { Commissioners }\end{array}$ & Liberty County & Yes \\
\hline Manatee County Area Transit & City of Bradenton & Yes \\
\hline Martin County & Martin County & No \\
\hline Miami Lakes - vRide, Inc. & City of Miami Lakes & No \\
\hline Miami-Dade Transit & City of Miami & Yes \\
\hline Nassau Council on Aging & Nassau County & Yes \\
\hline $\begin{array}{l}\text { Okaloosa County Board of County } \\
\text { Commissioners }\end{array}$ & Okaloosa County & Yes \\
\hline Pasco County Public Transportation & Pasco County & Yes \\
\hline Pinellas Suncoast Transit Authority & City of St. Petersburg & Yes \\
\hline Polk County Transit Services & Polk County & Yes \\
\hline Ride Solution & Putnam County & Yes \\
\hline Sarasota County Area Transit & Sarasota County & Yes \\
\hline Senior Resource Association, Inc. & Indian River County & Yes \\
\hline $\begin{array}{l}\text { South Florida Regional } \\
\text { Transportation Authority }\end{array}$ & City of Pompano Beach & No \\
\hline Space Coast Area Transit & City of Cocoa & Yes \\
\hline $\begin{array}{l}\text { St Johns County, Florida, Board of } \\
\text { County Commissioners }\end{array}$ & City of St. Augustine & Yes \\
\hline $\begin{array}{l}\text { Sumter County Board of County } \\
\text { Commissioners }\end{array}$ & Sumter County & No \\
\hline $\begin{array}{l}\text { Suwannee River Economic Council, } \\
\text { Inc. }\end{array}$ & $\begin{array}{l}\text { Bradford, Gilchrist, Lafayette, } \\
\text { and Dixie Counties }\end{array}$ & No \\
\hline Suwannee Valley Transit Authority & $\begin{array}{l}\text { Suwannee, Columbia, and } \\
\text { Hamilton Counties }\end{array}$ & Yes \\
\hline $\begin{array}{l}\text { Tampa Bay Area Regional } \\
\text { Transportation Authority }\end{array}$ & City of Tampa & No \\
\hline Tri-County Community Council & $\begin{array}{l}\text { Holmes, Walton, and } \\
\text { Washington Counties }\end{array}$ & No \\
\hline Veloia - Central Florida RPC & $\begin{array}{l}\text { Highlands, DeSoto, Hardee, } \\
\text { and Okeechobee Counties }\end{array}$ & No \\
\hline VPSI & Lake County & No \\
\hline Wakulla County Transportation & Wakulla County & Yes \\
\hline
\end{tabular}




\subsection{Mapping Florida Level of Service Data}

In the North Dakota survey, transit agencies were given a map and asked to identify their service areas. The service areas on the map represented census tracts, and the collected data could be easily mapped. Because the Florida survey was not conducted with a map, mapping the resulting service data required a few extra steps. Florida transit providers were asked to identify counties and cities within their service area, as well as the level of service provided in each of those areas. To map the Florida data required an association between census tracts and the municipalities or rural areas listed in the survey.

Using census tracts for mapping is desirable because of the availability of tract-level population and demographic data from the American Community Survey (ACS). Census tracts also provide greater detail than simple county-level data. To map the Florida level of service data, census tracts were assigned either to one of the state's cities or, if the tract was completely outside any city, it was assigned to "other rural areas" for its county. Using ArcGIS, census tracts were merged to create 450 geographic areas for the state, representing individual cities and one rural area for each county. These 450 geographic areas matched the areas included in the survey.

\subsection{Survey Results Summary}

\subsubsection{Type of Service Provided}

More than $50 \%$ of the responding transit agencies (23 of 41) in Florida provide traditional fixedroute transit service. DRT service for the general public is provided by 22 responding agencies, and ADA complementary paratransit service is provided by 27 agencies. Table 5.2 summarizes the types of service provided by the transit agencies in Florida. Most (36 of 41) provide door-todoor service and about half provide curb-to-curb service (Table 5.3) Among the transit agencies that provide traditional-fixed route service, most (22 of 23) provide ADA complementary paratransit, almost half (10 of 23) provide DRT service for the general public, eight provide limited-eligibility DRT service for certain rider groups, nine provide human service transportation for clients of human service programs, and seven provide veterans transportation. 
Table 5.2 What type of transportation services does your organization provide (check all that apply)?

\begin{tabular}{lcc}
\hline Service Type & $\begin{array}{c}\text { Number of } \\
\text { Agencies }\end{array}$ & $\begin{array}{c}\text { Percentage } \\
\text { of } \\
\text { Respondents }\end{array}$ \\
\hline Traditional-fixed route & 23 & $56 \%$ \\
Flexible route & 15 & $37 \%$ \\
ADA complementary paratransit & 27 & $66 \%$ \\
Demand-response for the general public & 22 & $54 \%$ \\
Limited-eligibility demand-response (serving only certain rider groups) & 14 & $34 \%$ \\
Human service transportation (for clients of human service programs) & 17 & $41 \%$ \\
Veterans transportation & 16 & $39 \%$ \\
\hline
\end{tabular}

Table 5.3 Do you provide the following types of service (check all that apply)?

\begin{tabular}{lcc}
\hline Service Type & $\begin{array}{c}\text { Number of } \\
\text { Agencies }\end{array}$ & $\begin{array}{c}\text { Percentage } \\
\text { of } \\
\text { Respondents }\end{array}$ \\
\hline Fixed-route & 24 & $59 \%$ \\
Curb-to-curb & 20 & $49 \%$ \\
Door-to-door & 36 & $88 \%$ \\
Door-through-door or escort service & 4 & $10 \%$ \\
\hline
\end{tabular}

\subsubsection{Service Span and Coverage}

Service span of the DRT service in Florida was collected for all cities in a county and for other rural areas in that county. Figures 5.1 to 5.4 map the days of service per week and hours per day throughout the state. Transit agencies were differentiated between those providing service to the general public and those whose service is available only to specific transportation-disadvantaged populations. Unlike North Dakota, where most of the agencies provide demand-response service to the general public, many of the DRT providers in Florida serve only the transportationdisadvantaged. Identifying service eligibility is important when assessing level of service across the state.

The maps in Figures 5.1 and 5.2 show data for all types of DRT services, including ADA paratransit and limited-eligibility services, as well as those serving the general public. However, care needs to be taken when interpreting the results because transportation providers serving the transportation-disadvantaged may have different eligibility requirements. More detail regarding eligibility requirements would be needed to identify service availability for specific population groups. 
Service span maps, as shown in Figures 5.3 and 5.4, were also created for DRT service available to the general public. Survey results indicate that among Florida transit agencies operating DRT service, many do not provide service for the general public. This may be because fixed-route transit is available in the regions where DRT is not available for general public.

Figures 5.1 and 5.3 show most DRT agencies in Florida provide service 6 or 7 days a week. Figures 5.2 and 5.4 indicate that most of the areas in Florida have hours of service per day in the range of 12 to 15.9 hours or 16 or more hours. There are a few areas for which the service data were not available because a survey response was not received from their agencies or no service data was available from their websites. DRT service is not available for the general public for many areas in Florida. Many of the transit agencies, however, provide fixed-route service for the general public (23 out of 41), so there may not be a great need to provide DRT service for the general public unless warranted. Further, the figures show that there are very few areas in Florida which have no service or very limited service. It should be noted that since not all transit agencies in Florida responded to the survey, there could be some inaccuracies in the data. For example, some areas may be served by more than one provider, and data for missing agencies is not included.

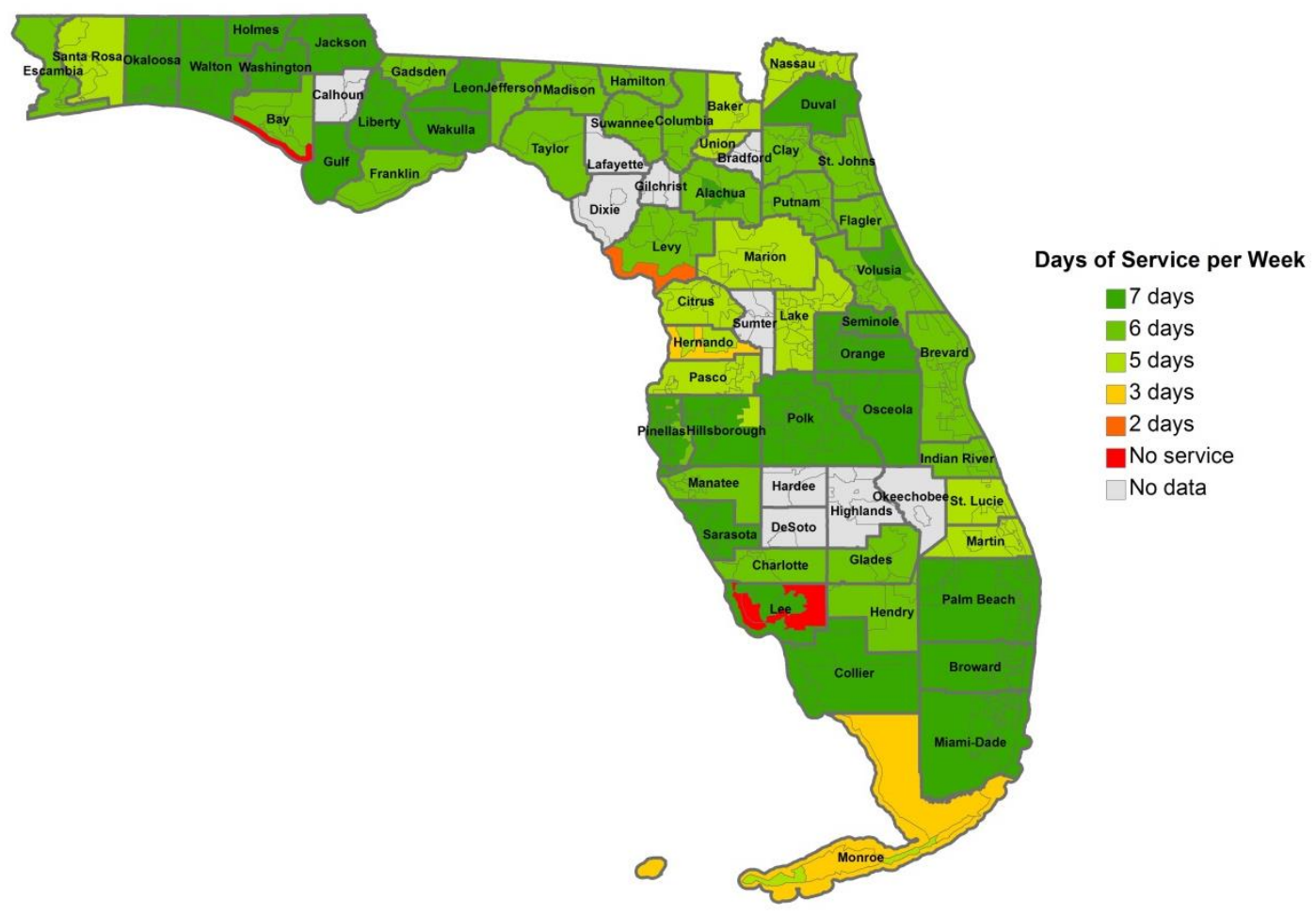

Figure 5.1 Days of Service per Week for Demand-Response Transit in Florida, Including All Types of Services 


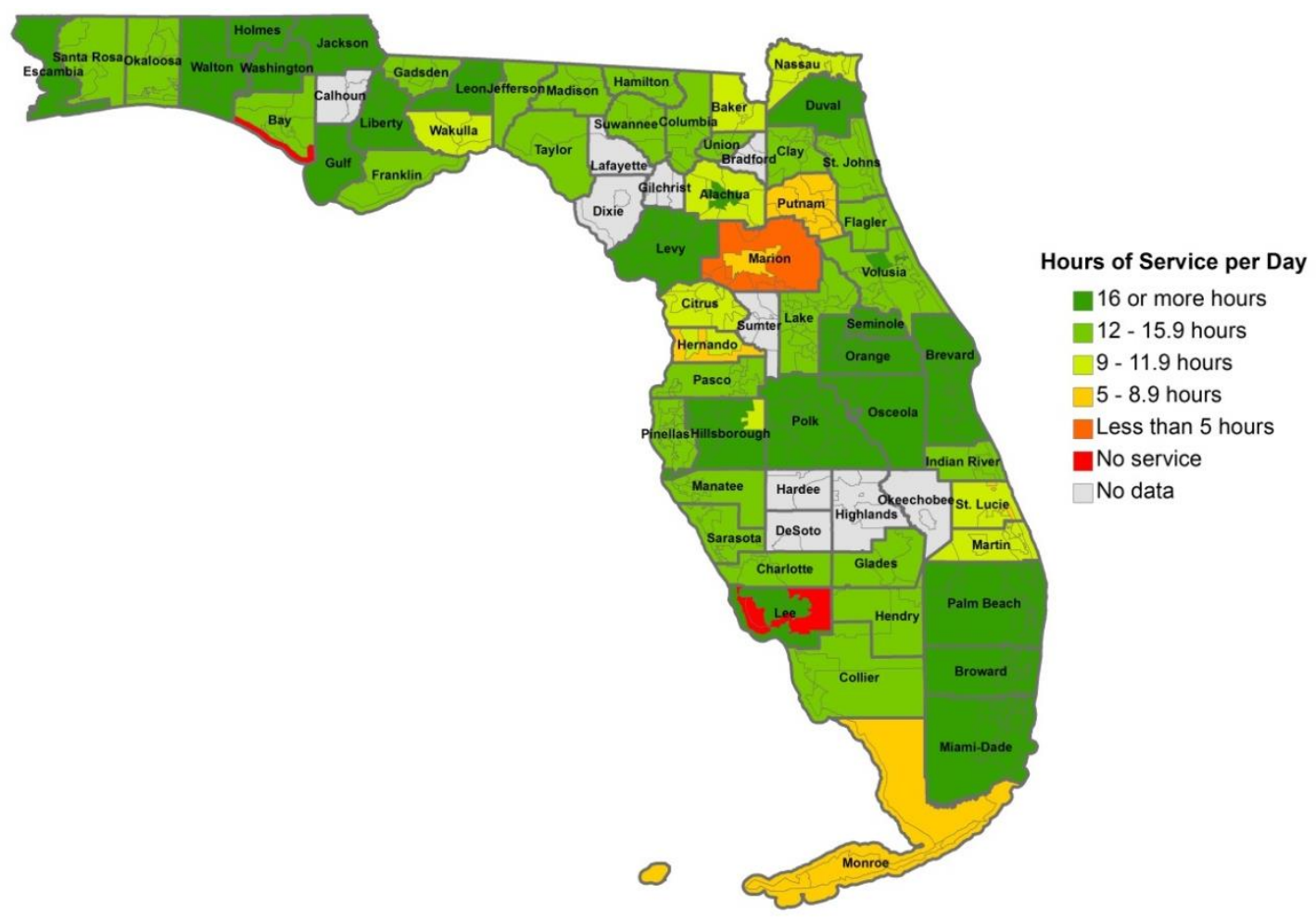

Figure 5.2 Hours of Service per Day for Demand-Response Transit in Florida, Including All Types of Services

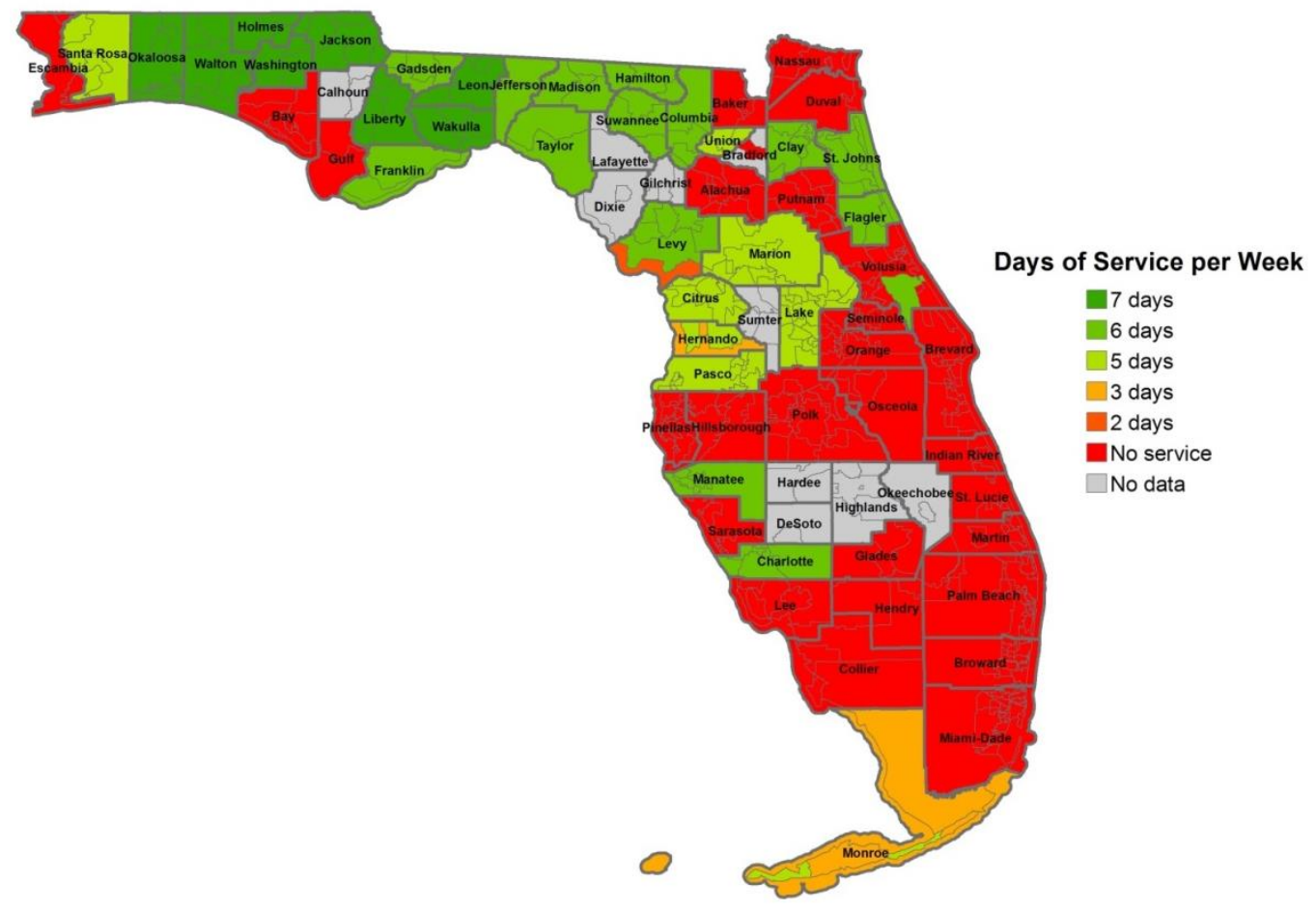

Figure 5.3 Days of Service per Week for Demand-Response Transit in Florida for the General Public 


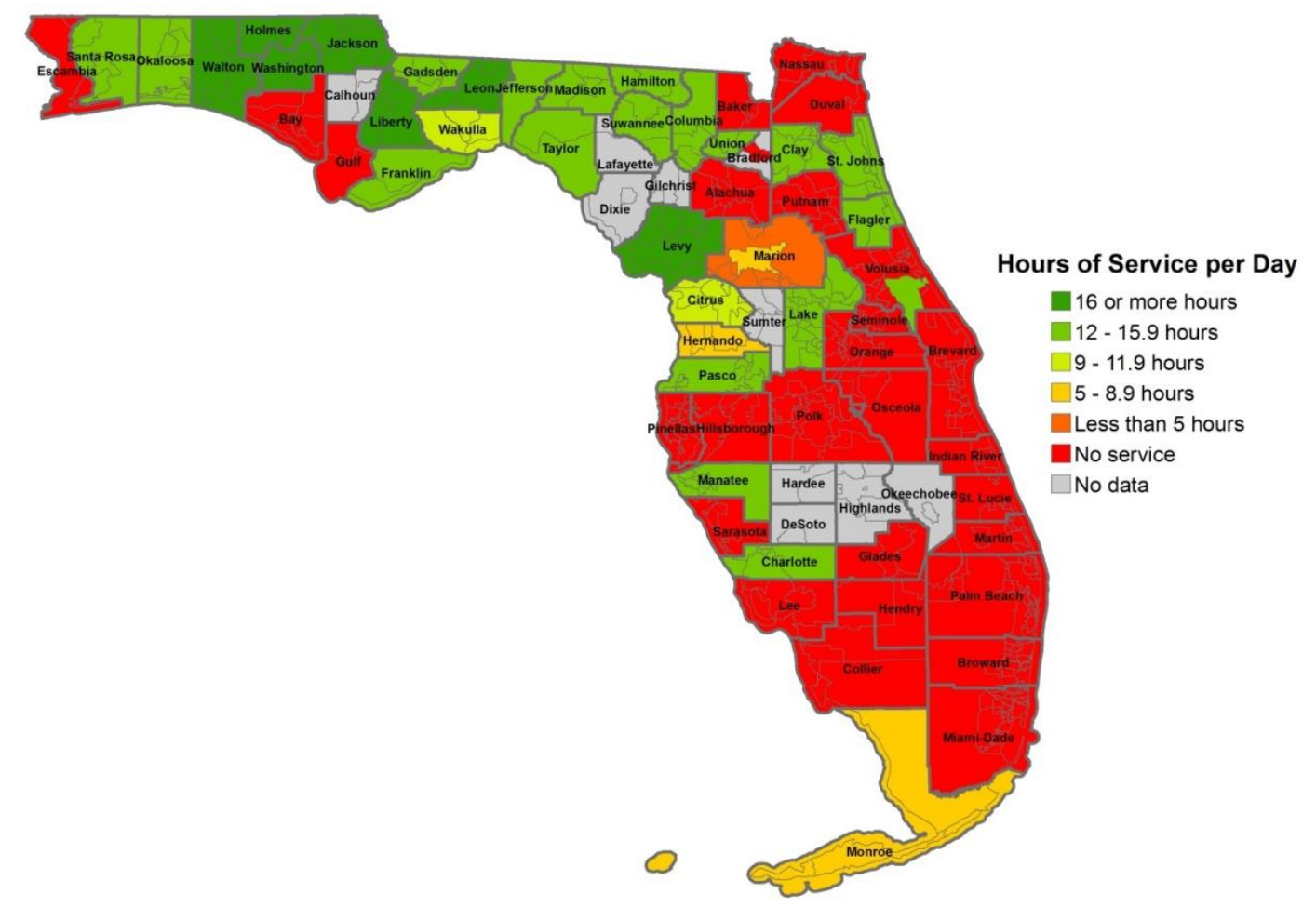

Figure 5.4 Hours of Service per Day for Demand-Response Transit in Florida for the General Public

Using the number of days of DRT service and hours of service per day, the level of service of the DRT service for the areas in Florida was calculated using the methodology described in Section 2. Figure 5.5 shows the level of service for all types of DRT services for counties/communities in Florida, except for the few counties for which the data were not available. Similarly, Figure 5.6 shows the level of service for DRT service for the general public. Detailed data are also provided in Appendix E.

Level of service was found to be highest (LOS 1) in the following areas:

- Escambia county

- Walton county

- Holmes county

- Washington county

- Jackson county

- Gulf county

- Liberty county

- Leon county

- Duval county

- City of Gainesville in Alachua county

- Levy county except for Inglis (LOS 5) and Yankeetown (LOS 5)

- Daytona Beach and Dayton Beach Shores of Volusia county

- Seminole county 
- Orange county

- Brevard county

- Osceola county

- Polk county

- Hillsborough county except for Plant City (LOS 4)

- Lee county except for Sanibel (LOS 8) and its other rural areas

- Palm county

- Broward county

- Miami-Dade county

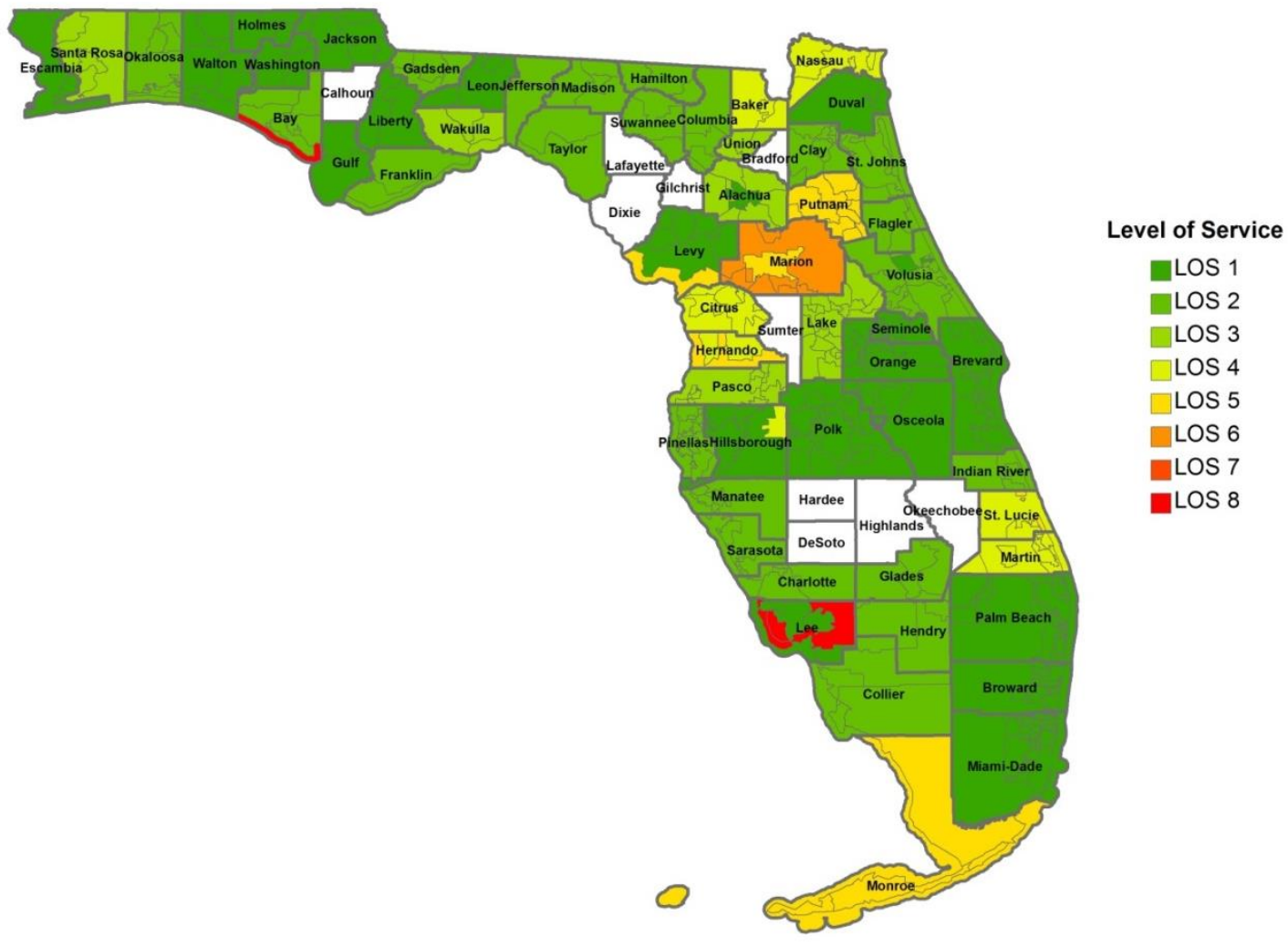

Figure 5.5 Level of Service for Demand-Response Transit in Florida, Including All Types of Services 


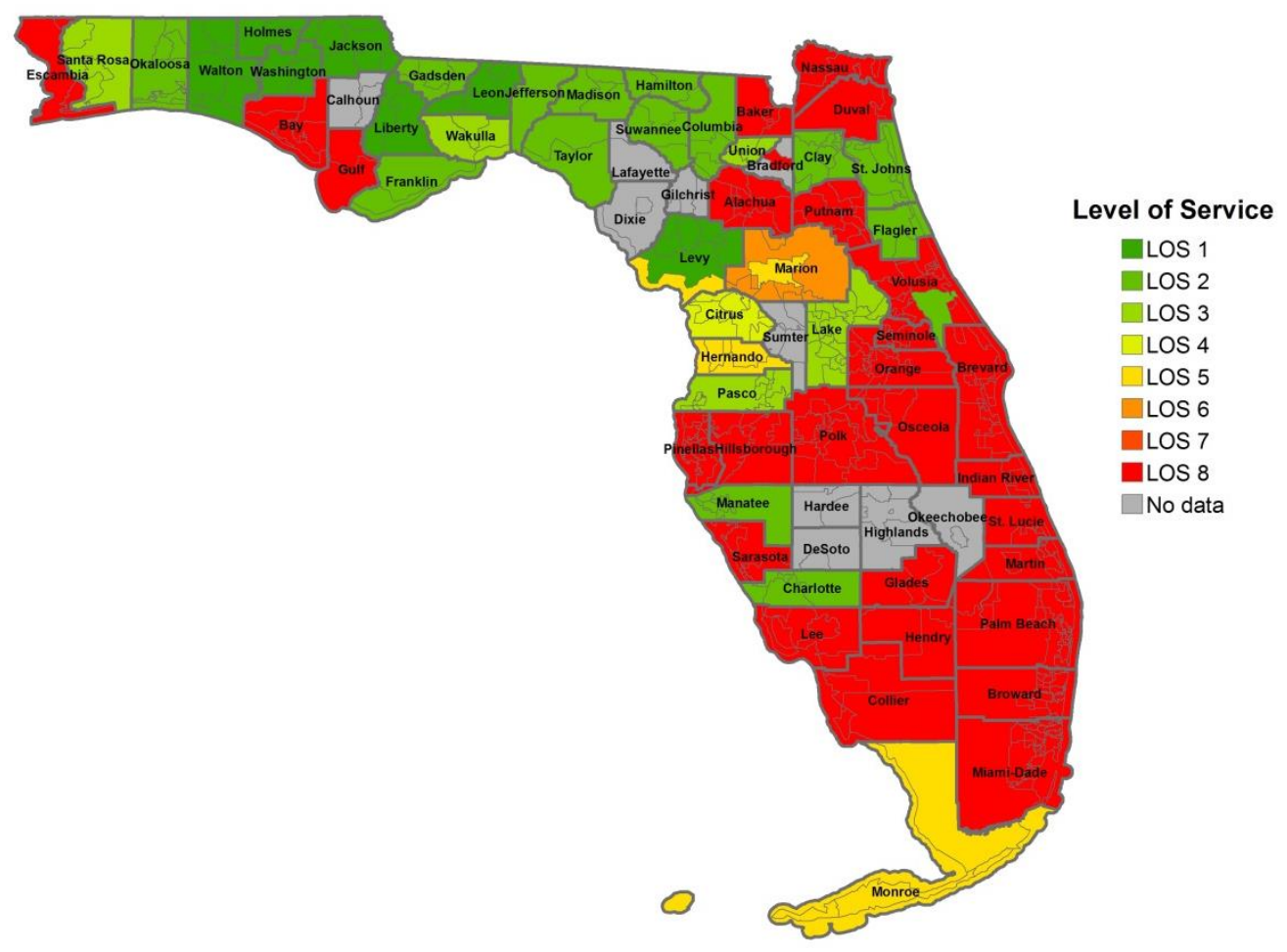

Figure 5.6 Level of Service for Demand-Response Transit in Florida for the General Public

All of the ADA complementary paratransit providers in Florida offer service within $3 / 4$ mile of fixed routes, and a few provide service beyond that requirement. Central Florida Regional Transportation Authority provides ADA paratransit service throughout the counties of Orange, Osceola, Polk, and Seminole. Florida County Board of County Commissioners, Miami-Dade Transit, Broward County Transit, and Council on Aging of St. Lucie provide complementary paratransit throughout the counties of Flagler, Miami-Dade, Broward, St. Lucie. Regional Transit System and Starmetro provide ADA complementary paratransit within the city limits of Gainesville and Tallahassee and within $3 / 4$ mile of all fixed routes when outside the city limits. Among the 27 transit agencies in Florida who provide ADA paratransit service, 18 agencies mentioned that senior citizens, in addition to those with disabilities, are eligible for service, and 16 agencies mentioned other categories of people that are also eligible.

\subsubsection{Advance Reservation Time}

In the survey that was distributed to transit agencies in Florida, respondents were asked to identify the minimum advance reservation time for DRT service, using categories from the TCQSM second edition. Table 5.4 shows that transit agencies in Florida commonly require reservations to be made 24 hours in advance, or during the previous service day. However, a few transit agencies ( 9 out of 39 responded) require reservations to be made 48 hours in advance, or two days in advance. 
Table 5.4 What is the minimum advance reservation time for your agency operating demand-response or complementary paratransit?

\begin{tabular}{lcc}
\hline Minimum Advance Reservation Time & $\begin{array}{c}\text { Number of } \\
\text { Agencies }\end{array}$ & $\begin{array}{c}\text { Percentage of } \\
\text { Respondents }\end{array}$ \\
\hline Up to 1/2 hour & 1 & $3 \%$ \\
More than 1/2 hour and up to 2 hours & 0 & $0 \%$ \\
More than 2 hours, but still same day & 1 & $3 \%$ \\
24 hours in advance, or prior service day & 25 & $64 \%$ \\
48 hours, or 2 days, in advance & 9 & $23 \%$ \\
More than 48 hours in advance, and up to 1 week & 3 & $8 \%$ \\
More than 1 week in advance, and up to 2 weeks & 0 & $0 \%$ \\
More than 2 weeks & 0 & $0 \%$ \\
\hline
\end{tabular}

\subsection{Evaluation of Survey}

The survey yielded a response rate of $68 \%$. Because this study was intended to gather service details for all counties in the state, a response rate closer to $100 \%$ would have been more useful. Nevertheless, service details were gathered for seven additional transit agencies via transit agency websites or by phone, resulting in service details available for $80 \%$ of the 56 transit agencies listed in in NTD.

The goal of the survey was to collect as much useful and detailed data as possible while minimizing error and the reporting burden for transit agencies. A successful survey should be clear and simple for agencies to complete. To evaluate the survey in this regard, two questions were added to the end of the survey to gather feedback from the transit agencies regarding the survey instrument. The first of these questions asked respondents how easy it was for them to complete the survey (using a seven-point Likert scale). The second was an open-ended question asking if any questions were difficult to answer or unclear.

Feedback from the transit agencies was quite positive. Most respondents said that the survey was easy to complete (Figure 5.7). Specifically, 21 out of 45 answered that it was very easy, and another 12 said it was easy. Only two answered that it was somewhat difficult, and none indicated that it was either difficult or very difficult. 


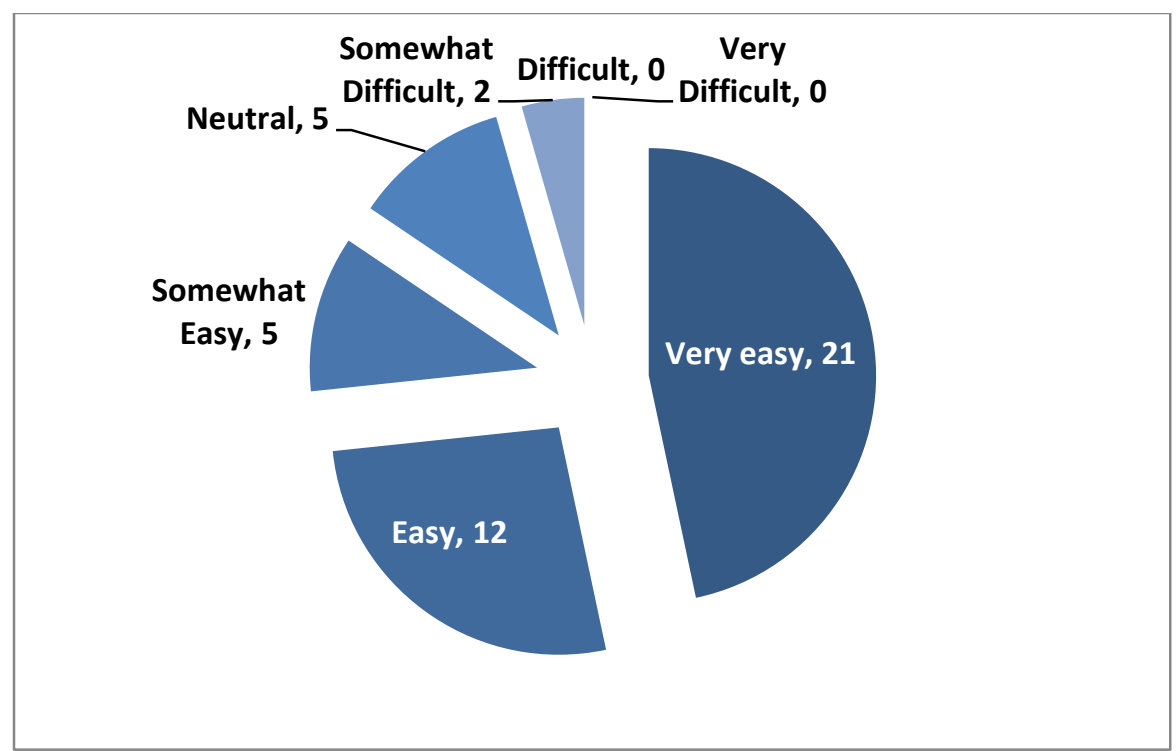

Figure 5.7 Florida Transit Agency Opinions Regarding the Ease of Completing the Survey

Very few comments were received regarding questions that were unclear or difficult to answer. One respondent commented that there should be an "other" option for reservation times, because there can be a wide variety of potential answers. Another respondent was not sure if questions were limited to ADA paratransit or all paratransit. A response from one agency also suggests that the survey is somewhat limited in its ability to capture all information about the service being provided. For example, that agency provides the same number of hours on Saturday but limits the types of transportation-disadvantaged trips.

As noted, most agencies found the survey easy to complete, and it also did not require a significant time commitment. Most agencies completed the survey within 5-15 minutes, and many completed it within 10 minutes. Time commitment would be greater for agencies serving multiple counties and providing different levels of service within the counties. By replacing the map tool used in the North Dakota survey with a set of simple questions, it was easier for the transit agencies to provide the necessary information. Furthermore, the data collected from the Florida survey was more detailed because it included specific data for every city in the state. The data were also of a higher quality. The way the Florida survey was designed left fewer possibilities for data collection error. The only drawback of the survey was that mapping the survey data and comparing those results to ACS population data required a few additional steps, as discussed in Section 5.2. 


\section{PRIORITY RANKING FOR DEMAND-RESPONSE TRANSIT SERVICE IMPROVEMENTS}

While level of service values and service coverage data derived in Sections 4 and 5 provide valuable information about the extent of DRT service, these measures do not completely identify if the mobility needs of transit-dependent populations are being met, nor do they identify the areas with the greatest needs for service improvements. There should be a sound procedure to understand the population dependent on DRT service and if enough service is being provided. Also, there is a need to understand which locations have greater needs for new or improved service. Such assessments can be made by comparing level-of-service data with population and demographic data.

\subsection{Mobility Needs Index}

Population and demographic data provide guidance for determining where the greatest needs for mobility services exist. There is no generally accepted, low-cost methodology for accurately measuring mobility needs in a community. Previous research by Mielke et al. (2005) and Mattson and Hough (2015) developed a mobility needs index to identify counties in North Dakota with the greatest need for mobility services. This study uses the previously developed model and applies it to areas in North Dakota and Florida.

The factors deemed important for determining mobility needs are population aged 65 or older, population with a disability, and population below the poverty line. Census tract level data from the American Community Survey 2009-2013 five-year estimates were collected for total population 65 or older, total population with a disability (including all age groups), and total population with income below the poverty line. Population densities were then calculated for each of these three population groups. Next, the geographic areas were ranked from highest population densities to lowest population densities and grouped into five equally sized classes, using quintile values for each of the three factors. Geographic areas in the lowest $20 \%$ were given a value equal to 1 , the next $20 \%$ were given a value equal to 2 , and so on, while the highest $20 \%$ were given a value of 5 . In the last step, the three values were averaged for each geographic area to produce its mobility needs index. The process thus ranks all regions on a scale of 1 to 5 , with higher values identifying areas with greater mobility needs. While the procedure does not directly measure need, the measure can be used as a proxy for need.

The resulting mobility needs indices for North Dakota and Florida are mapped in Figures 6.1 and 6.2. As noted by Mielke et al. (2005), this methodology is only an attempt to measure needs associated with identifiable demographic groups. This measurement does not suggest that all needs are unmet. On the contrary, some cities may have systems and services in place that satisfy many residents' mobility needs. 


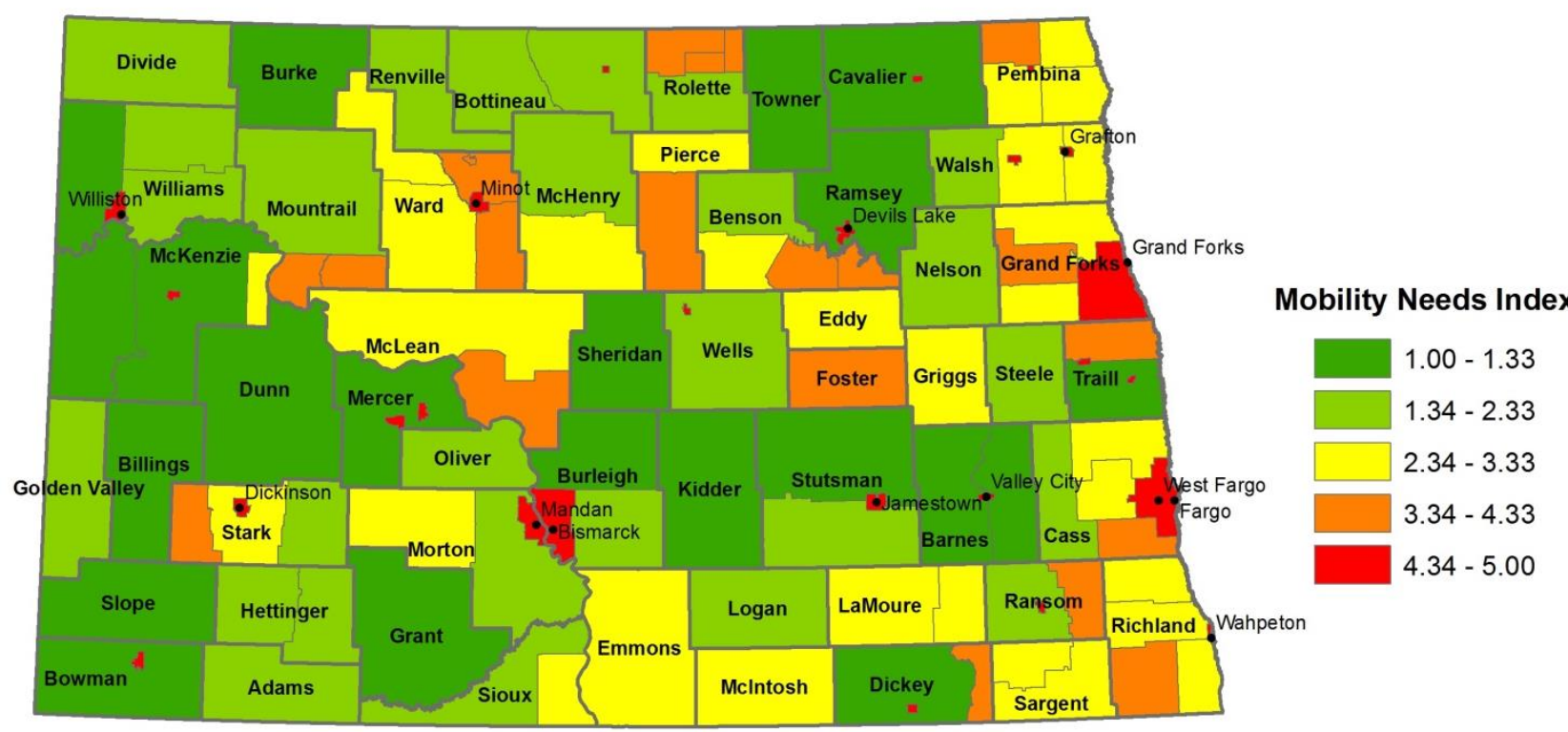

Figure 6.1 Mobility Needs Index for North Dakota

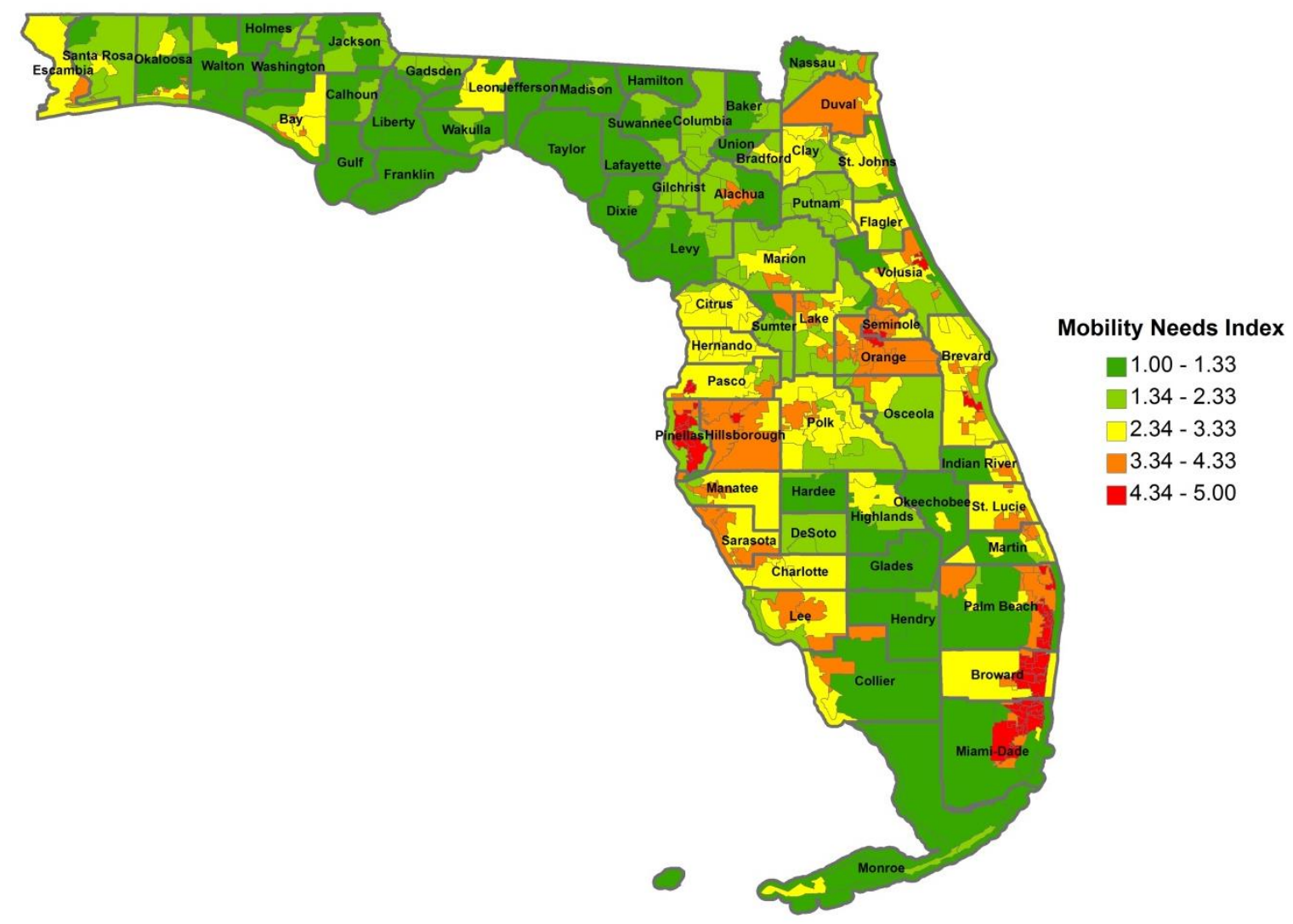

Figure 6.2 Mobility Needs Index for Florida 


\subsection{Identifying Priorities for Service Improvements}

Comparing the mobility needs index with the existing level of service provides information about where the greatest needs exist for service improvements. This study developed a method of combining these two sources of information to rank areas in terms of needed improvements. This information can help transit agencies, MPOs, and state DOTs make investment decisions for planning or improving DRT service.

The priority rank incorporates two factors: the mobility needs index and the existing level of service, as calculated in previous sections using span-of-service data. Combining these two sources of data, a matrix was created to prioritize needed service improvements, as shown in Table 6.1. To determine the priority rank for an area, first determine the level of DRT service available. From the column in Table 6.1 showing the level of service (LOS), determine the mobility needs index for the area to identify the priority rank. A scale of 1-10 is used, where a priority rank of 1 indicates the greatest need for service improvements, and a priority rank of 10 indicates the least need.

Areas with a high population density (and therefore a high mobility needs index) and low level of service have the highest priority for service improvements. Those areas with a low population density (and low mobility needs index) and high level of service have little or no need for service improvements. As the table shows, areas with a higher mobility needs index or lower level of service have greater priority for improvements. However, identifying priorities is subjective. This table provides one possible method for prioritizing needs, but different transit planners and decision-makers may have their own preferred priority rankings. The point of this exercise is to demonstrate how the level-of-service data collected in this study could be combined with ACS data to identify areas with the greatest needs for DRT service improvements.

Table 6.1 Priority Ranking Measure for Demand-Response Transit Service Improvements

\begin{tabular}{ccccccccc}
$\begin{array}{c}\text { Mobility } \\
\text { Needs Index }\end{array}$ & LOS 8 & LOS 7 & LOS 6 & LOS 5 & LOS 4 & LOS 3 & LOS 2 & LOS 1 \\
\hline $5-4.34$ & 1 & 1 & 2 & 2 & 4 & 7 & 7 & 8 \\
$4.33-3.34$ & 1 & 2 & 2 & 5 & 5 & 8 & 8 & 9 \\
$3.33-2.34$ & 2 & 2 & 4 & 5 & 6 & 9 & 9 & 9 \\
$2.33-1.34$ & 3 & 3 & 5 & 6 & 8 & 9 & 9 & 10 \\
$1.33-1.00$ & 4 & 4 & 6 & 8 & 9 & 10 & 10 & 10 \\
\hline
\end{tabular}


For the states of North Dakota and Florida, DRT level-of-service values were estimated for all geographic areas, as shown in Sections 4 and 5, and the mobility needs indices were calculated for these geographic areas using ACS data, as shown in Figures 6.1 and 6.2. Using the mobility needs index values and level-of-service values of DRT for all census tracts, and following the procedure from Table 6.1, the priority ranks for all geographic areas in the two states were estimated and mapped (Figures 6.3 and 6.4). The Florida priority rankings were calculated based on all services currently available (including both transportation-disadvantaged and general public service). Detailed data for Florida are also provided in Appendix E.

As indicated in Figures 6.3 and 6.4, the areas with higher priority rankings, those ranked 1-5 and colored red or orange, are the locations where the mobility needs are not being met as well with DRT service and where there should be greater priority for DRT investments.

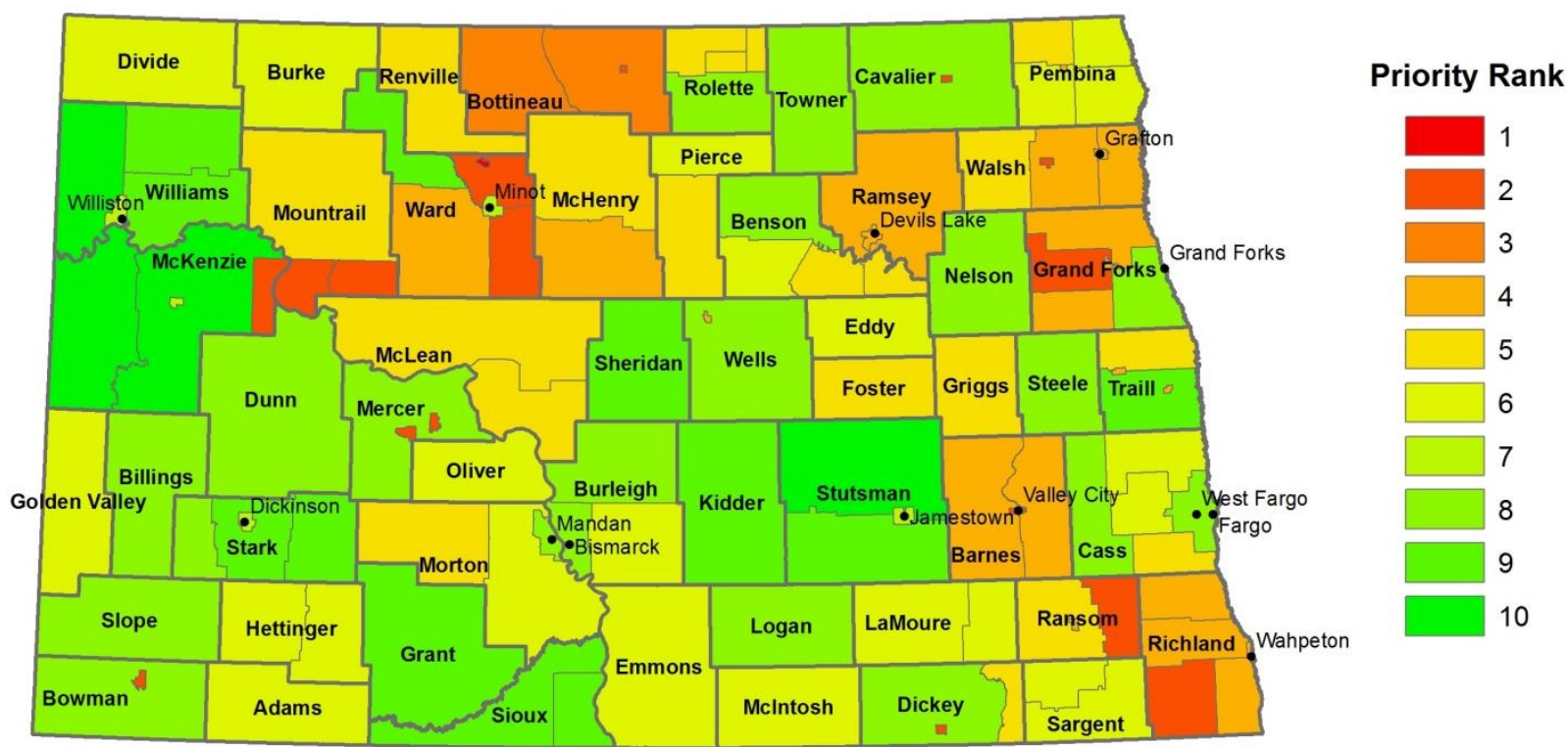

Figure 6.3 Priority Ranking for Receiving Demand-Response Service Improvements in North Dakota 


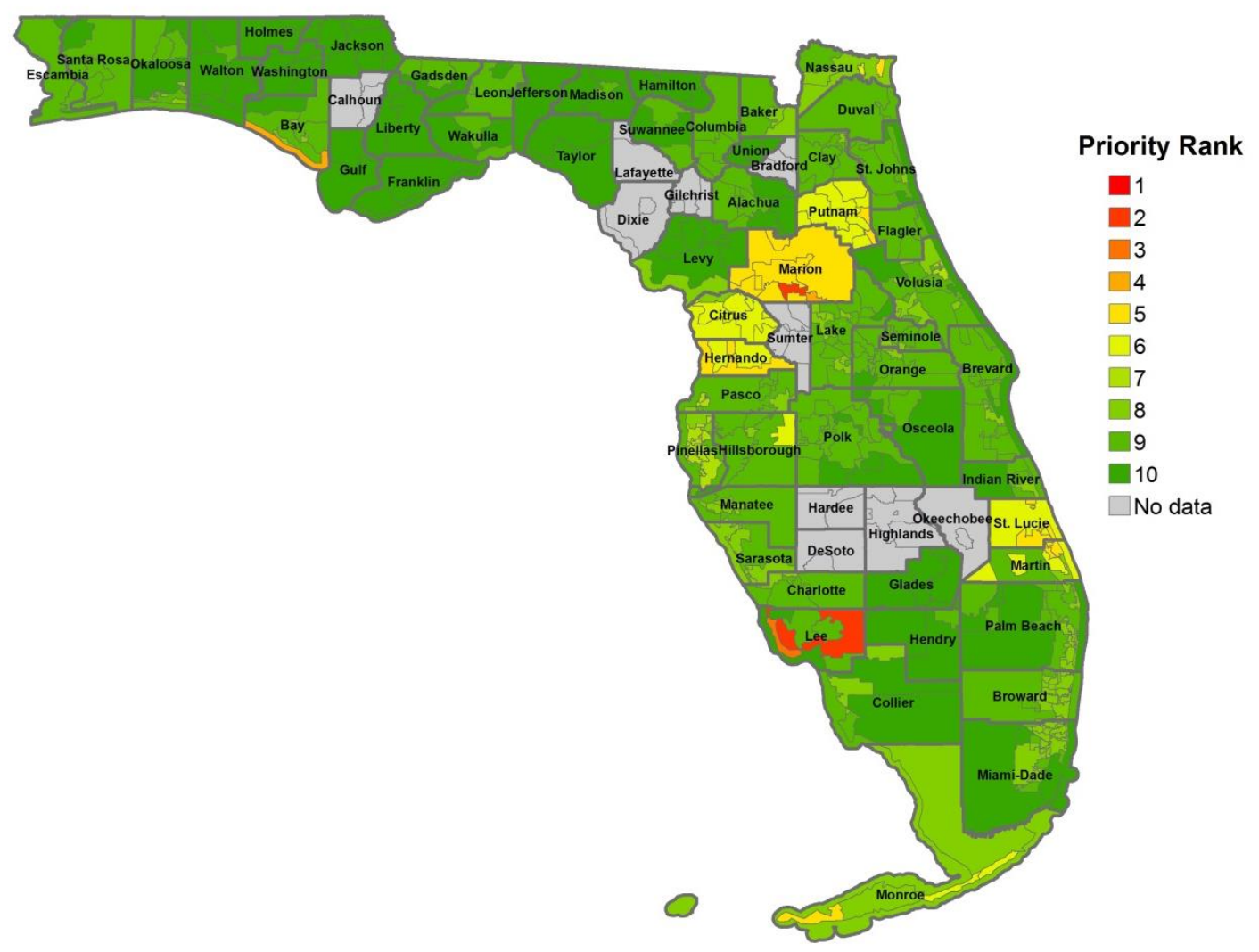

Figure 6.4 Priority Ranking for Receiving Demand-Response Service Improvements in Florida 


\section{CONCLUSIONS AND RECOMMENDATIONS}

\subsection{National Demand-Response Transit Level of Service Study Framework}

To demonstrate the procedure for calculating the national demand-response transit (DRT) level of service, the study selected two pilot states (North Dakota, a largely rural state; and Florida, a state with a mix of large urban, small urban, suburban, and rural areas). Results can be used to demonstrate how to determine DRT service coverage in any state. The methodology for determining the DRT level of service was adapted from the second edition of the Transit Capacity and Quality of Service Manual (TCQSM). As ADA paratransit service is a type of DRT service, it is included while calculating DRT level of service coverage.

\subsection{NTD Data Deficiencies}

The study considered the National Transit Database (NTD) and rural NTD and evaluated the use of the available data from these databases for determining the national DRT service coverage. According to the framework that was used in the study to determine the national DRT level of service, the data that is considered essential for DRT agencies is service span, service area, and service eligibility. While service span data are available for some transit agencies in the NTD, the data are not consistent, and service span data are not available for any transit agencies in the rural NTD. Specific service coverage data and service eligibility data are also lacking from the NTD and the rural NTD. The NTD also lacks data on service type and advance reservation time. A significant limitation of the NTD is that is does not distinguish between ADA paratransit and other forms of DRT.

\subsection{Survey of Demand-Response Transit Agencies in North Dakota and Florida}

To gather additional service details for transit agencies, two different surveys were conducted with the DRT agencies in North Dakota and Florida. Surveys in both states collected information about service eligibility, service days per week, service hours per day, service area, service type, and minimum advance reservation time for transit agencies operating DRT. The two surveys employed different approaches, but both attempted to collected detailed data on geographic coverage and level of service. Transit agencies may provide DRT service within an entire county or only to certain communities, and they may provide different levels of service (in terms of days or hours) within their service area. ADA paratransit providers may offer service within $3 / 4$ miles of fixed-route service, as required, or they may provide service to a larger geographic area. The surveys conducted in North Dakota and Florida attempted to collect this level of detail. The goal in designing these surveys was to collect as much useful and detailed data as possible while minimizing the burden to transit agencies and the possibility for error.

A total of 27 out of 33 transit agencies in North Dakota responded to the first survey. The high response rate was influenced by the NDDOT requesting the agencies to respond. The online survey tool used a map tool that responding demand-response transit agencies could click on to indicate the geographic areas (census tracts/cities) where they offered any kind of DRT service. 
While the survey was mostly successful, the use of the clickable map tool in the survey was found to be somewhat ineffective, as the level of categorization of clickable geographic areas may confuse the respondents.

Based on the lessons learned with the first survey, the survey for the DRT agencies in Florida was designed using Qualtrics software. While the rest of the survey questionnaire was similar to the North Dakota survey, information on service area from the DRT agencies was gathered using a different approach. Transit agencies were first asked to identify counties in which they provide demand-response service. Then for the individual county or counties selected, the survey asked if the agency provides the same days and hours of service throughout the county or if they provide different levels of service in the county or do not serve some areas of the county. If service is the same throughout the county, the survey asked agencies to identify the number of days and hours of service provided in the county. If service differs, the survey then listed each city in the county and asked respondents to identify the number of days and hours of service for each city. Rural areas of the county not belonging to any city were also included in the survey and referred to as "other rural areas."

Of the 56 transit agencies in Florida, 38 responded to the survey. Because Florida is a more urban state, more than half of the transit agencies ( 23 of the 41 that responded) provide fixedroute service, 27 provide ADA paratransit service, and 22 provide demand-response service for general public. Despite the lower response rate (the Florida DOT did not request agencies to respond), the survey conducted in Florida was more successful. The survey collected a high level of detail regarding geographic coverage and span of service, it was less prone to error than the North Dakota survey, and feedback from transit agencies in Florida was more positive. Most responding agencies from Florida said that the survey was easy to complete, and very few mentioned any difficulties with the survey. Further, most agencies completed the survey within 5-15 minutes.

\subsection{National Demand-Response Level of Service}

This study attempted to determine the level of DRT service in North Dakota and Florida. The end result is a map with data at the city or census tract level showing days per week and hours per day of service, as well as a map combining these two measures into a single measure of level of service. Having achieved successful results, this method could be implemented in any state, provided that sufficient data are available. Although sufficient data are not available currently within the NTD, a survey tool similar to that used for the Florida survey could be designed to gather required service details for any state.

The study framework and results from this study procedure would be useful to transit agencies, MPOs, and state DOTs in order to plan DRT service for where the greatest needs exist for additional coverage. As a caveat, the level-of-service values calculated in this report were based on the accuracy of the transit agency service details provided by the survey respondents and available from their websites. Also, the service area or hours for some transit agencies may have changed by the time this report is published, so the data and results available from this report should be used as a baseline but not for making decisions until proper validation. 
Further, the scope of the study was to analyze the DRT level of coverage of transit agencies that are eligible to receive 5307 or 5311 grants, as these are the agencies required to report data to the NTD. However, there may be transit agencies providing some kind of DRT service for senior citizens, people with disabilities, or other transportation-disadvantaged riders that are not funded by 5307 or 5311 grants. In such cases, the level-of-service values determined may under-report the actual level of service available. To obtain more detailed information on level of service, these specialized transportation providers could be surveyed using the same survey tool and framework developed in this study.

\subsection{Priority Ranking for Receiving Demand-Response Service Improvements}

While DRT level of service can provide information about the extent of DRT service availability, it does not completely determine if the mobility needs of transit-dependent populations are properly met. Therefore this study also developed a priority ranking procedure to identify where the greatest needs for service improvements exist. Mobility needs index values were calculated for areas within a state using ACS population density data for older adults, people with disabilities, and those living below the poverty line. By comparing the mobility needs index values with existing levels of service, transit planners can more easily identify areas with the greatest needs for service improvements.

This procedure was demonstrated in North Dakota and Florida for identifying the locations which need service improvements based on unmet transit needs. While this procedure ranks all areas $1-10$, the ranking is subjective and can be modified according the priorities in any given state. The point of this exercise is to demonstrate how the level-of-service data collected in this study could be combined with ACS data to identify areas with the greatest needs for DRT service improvements.

\subsection{Recommendations}

Based on the framework adapted in this study to determine the national DRT level of service, DRT service details such as service eligibility, service span, and service area are considered critical for determining the coverage of DRT service. Therefore, having such data available in the NTD or elsewhere for all U.S. transit agencies operating any kind of DRT, including ADA paratransit, would be helpful for understanding the current level of service being provided and for identifying areas that should be priorities for service improvements.

As indicated by responses from the survey of Florida agencies, the reporting burden for transit agencies to provide this information is not too great. Further, availability of additional DRT service details such as type of service provided (door-to-door, curb-to-curb, etc.), and minimum advance reservation time would be helpful to better understand the demand-response quality of service and address the transit needs in an effective way.

Surveys conducted with transit agencies in North Dakota and Florida did not receive a $100 \%$ response rate, despite multiple reminder e-mails. However, the North Dakota survey received a very high response rate because of assistance from the state DOT. Making the survey mandatory, 
through the NTD or some other data collection method, would be needed to achieve a $100 \%$ response.

This study recommends using the survey instrument conducted for the Florida survey, as shown in Appendix D. This survey instrument was developed in this study just for use in the state of Florida, but a similar type of instrument could be developed that could be deployed nationwide. To create a survey tool that could be used nationwide, a database of all cities in the country would be needed with information about the county and state in which they are located. The survey tool would first ask the respondent to identify the state in which their agency located. Based on their response, respondents would be given a list of all the counties in their state and asked to identify the county or counties in which their agency provides service. The questionnaire would then follow the structure of the Florida survey. Respondents would be asked if their agency provides the same number of days and hours of service in the selected counties and, if not, they would be given a list of all cities in the county and asked to identify the number of days and hours of service in each city or rural area. Level of service data can then be mapped and compared to ACS population data by associating the cities and rural areas with census tracts.

Fixed-route transit has benefited from the development of general transit feed specification (GTFS) format transit data. Although this type of application is not available for demandresponse service, gathering more service details such as service span, service area, service type, service eligibility, and advance reservation time would be a major step toward development of online DRT trip planner tools. 


\section{REFERENCES}

Ellis, Elizabeth, and Brian McCollom. TCRP Report 136: Guidebook for Rural DemandResponse Transportation: Measuring, Assessing, and Improving Performance. Transit Cooperative Research Program, Washington, DC: Transportation Research Board, 2009.

GAO, ADA Paratransit Services: Demand Has Increased, but Little is Known about Compliance, GAO-13-17, November, 2012.

Gerty, Rosemary B, Thomas F. Procopio, Caroline R. Ferris, Elizabeth (Buffy) Ellis, and Sue Knapp. TCRP Report 143: Resource Guide for Commingling ADA and Non-ADA Paratransit Riders. Transit Cooperative Research Program, Washington, DC: Transportation Research Board, 2011.

Godavarthy, Ranjit, Jeremy Mattson, and Elvis Ndembe. 2015. "Cost-Benefit Analysis of Rural and Small Urban Transit in the United States." Transportation Research Record: Journal of the Transportation Research Board, 2533: 141-148.

Godavarthy, Ranjit, Jeremy Mattson, Del Peterson, and Jill Hough. 2015. "Developing a Method for Assessing National Demand-Response Transit Level of Service." Journal of Public Transportation, 18 (4): 1-15.

Godavarthy, Ranjit, Jeremy Mattson, and Elvis Ndembe. Cost-Benefit Analysis of Rural and Small Urban Transit. University of South Florida, Tampa: National Center for Transit Research, 2014.

KFH Group, Inc., Urbitran Associates, Inc., McCollom Management Consulting, Inc., and Cambridge Systematics, Inc. TCRP Report 124: Guidebook for Measuring, Assessing, and Improving Performance of Demand-Response Transportation. Transit Cooperative Research Program, Washington, DC: Transportation Research Board, , 2008.

Kittelson \& Associates, Inc., KFH Group, Inc., Parsons Brinckerhoff Quade \& Douglass, Inc., and Katherine Hunter-Zaworski. TCRP Report 100: Transit Capacity and Quality of Service Manual 2nd Edition. Transit Cooperative Research Program, Washington, DC: Transportation Research Board, 2003.

Kittelson \& Associates, Inc., Parsons Brinckerhoff, KFH Group, Inc., Texas A\&M Transportation Institute, and ARUP. TCRP Report 165: Transit Capacity and Quality of Service Manual Third Edition. Transit Cooperative Research Program, Washington, DC: Transportation Research Board, 2013.

Kittelson \& Associates, Inc., Urbitran Associates, Inc., LKC Consulting Services, Inc., MORPACE International, Inc., Queensland University of Technology, and Yuko Nakanishi. TCRP Report 88: A Guidebook for Developing a Transit PerformanceMeasurement System. Transit Cooperative Research Program, Washington, DC: Transportation Research Board, 2003. 
Mattson, Jeremy, and Jill Hough, Ph.D. Identifying and Satisfying the Mobility Needs of North Dakota's Transit System, DP-280. North Dakota State University, Fargo: Upper Great Plains Transportation Institute, 2015.

Mielke, Jon, Jim Miller, David Ripplinger, Del Peterson, and Jill Hough. "Personal Mobility in North Dakota: Trends, Gaps, and Recommended Enhancements." Departmental Report No. 165, Upper Great Plains Transportation Institute, North Dakota State University, 2005.

National Center for Transit Research. National Transit Level of Service Data and Analysis. September 2012. http://www.nctr.usf.edu/2012/09/national-transit-network-level-ofservice-data-and-analysis-2/ Accessed June 2015.

Weiner, Richard. TCRP Synthesis 76: Integration of Paratransit and Fixed-Route Transit Services. Transit Cooperative Research Program, Washington, DC: Transportation Research Board, 2008. 


\section{APPENDIX A. ADA COMPLEMENTARY PARATRANSIT}

ADA complementary paratransit is a type of DRT service, and it is important to include ADA paratransit service when assessing DRT service coverage because it provides transportation options for people with disabilities. The Americans with Disabilities Act (ADA) requires agencies operating fixed-route service to provide complementary paratransit for those not able to use fixed-route service. Generally, it must operate in the same areas and during the same hours as available fixed-route transportation.

Since the enactment of ADA, the demand for ADA complementary paratransit has increased (GAO 2012). The United States Government Accountability Office (GAO) conducted a webbased survey in 2012 with a sample of 145 transit agencies from a total of 546 identified transit agencies that provided demand-response service to determine the changes that have occurred to ADA paratransit demand and costs since 2007 (GAO 2012). The study found that most of the transit agencies $(73 \%)$ observed an increase $(12 \%)$ in individuals registered for ADA paratransit service and about $64 \%$ of the transit agencies provided more (7\%) ADA paratransit trips in 2010 than in 2007 (GAO 2012). A primary reason for this increase was that individuals with disabilities relied more on ADA paratransit services for transportation than their previous source of transportation (GAO 2012). However, ADA paratransit trips can be very expensive when compared to fixed-route trips.

Where possible, transitioning passengers from paratransit service to fixed-route service can be an effective measure to reduce the demand for paratransit service in some locations. At the same time, shifting passengers from paratransit to fixed-route service allows agencies to provide a wider variety of destinations with fixed-route service without a need for pre-scheduling their travel (GAO 2012). This method of integrating fixed-route and paratransit is called flexible services, and successful implementation of these services would require transit agencies to undergo an eligibility screening process, determine new operational procedures, and provide extensive travel training (Weiner 2008). Similarly, agencies operating ADA paratransit services may also provide service for non-ADA paratransit riders on the same vehicles at the same time and this is called "commingling" of ADA and non-ADA riders. Gerty et al. (2011) studied the commingling of ADA paratransit riders with other rider groups and found that most of the transit agencies they studied that adapted commingling services have commingled human service transportation riders and general public dial-a-ride with ADA paratransit riders. There are various ways and techniques for transit agencies to provide transportation options for passengers relying on some kind of DRT service. 


\section{APPENDIX B. SURVEY TOOL USED FOR DEMAND-RESPONSE LEVEL OF SERVICE STUDY - NORTH DAKOTA}

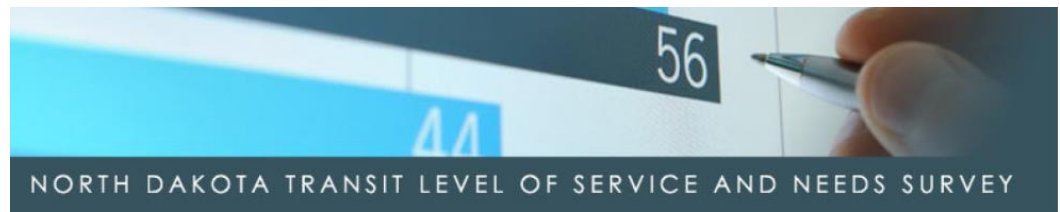

Questions marked with an asterisk (*) are required.

1. *Organization name:

2. Person Completing Survey

Name:
Title:
City:
Email:
Phone:

3. *What types of transportation services does your organization provide (check all that apply)?
$\square$ Traditional fixed-route
$\square$ Flexible route
$\square$ ADA complementary paratransit
$\square$ Demand-response for the general public
$\square$ Limited-eligibility demand-response (serving only certain rider groups)
$\square$ Human service transportation (for clients of human service programs)
$\square$ Veterans Transportation

4. *Do you provide the following types of service (check all that apply)?

$\square$ Fixed-route

$\square$ Curb-to-curb

$\square$ Door-to-door

Door-through-door or escort service

$\square$ None of the above

5. *In which counties does your organization provide transportation services?

6. *How many days per week do you provide service? Check all that apply if the number of service days differs in your service region.
$\square$ Areas with service $\mathbf{7}$ days per week
Areas with service $\mathbf{6}$ days per week
$\square$ Areas with service $\mathbf{5}$ days per week
Areas with service $\mathbf{4}$ days per week
Areas with service $\mathbf{3}$ days per week
$\checkmark$ Areas with service $\mathbf{2}$ days per week
Areas with service $\mathbf{1}$ day per week
$\square$ Areas with service less than weekly

7. *How many hours per service day do you provide service? Check all that apply if the number of hours differs in your service region.
Areas with $\mathbf{1 6}$ or more hours per service day
Areas with 12 to $\mathbf{1 5 . 9}$ hours per service day
Areas with $\mathbf{9}$ to $\mathbf{1 1 . 9}$ hours per service day
Areas with $\mathbf{5}$ to $\mathbf{8 . 9}$ hours per service day
$\square$ Areas with less than $\mathbf{5}$ hours per service day 
Questions marked with an asterisk (*) are required.

8. *Please click the areas with service $\mathbf{7}$ days per week in the map where your organization provides transportation services.
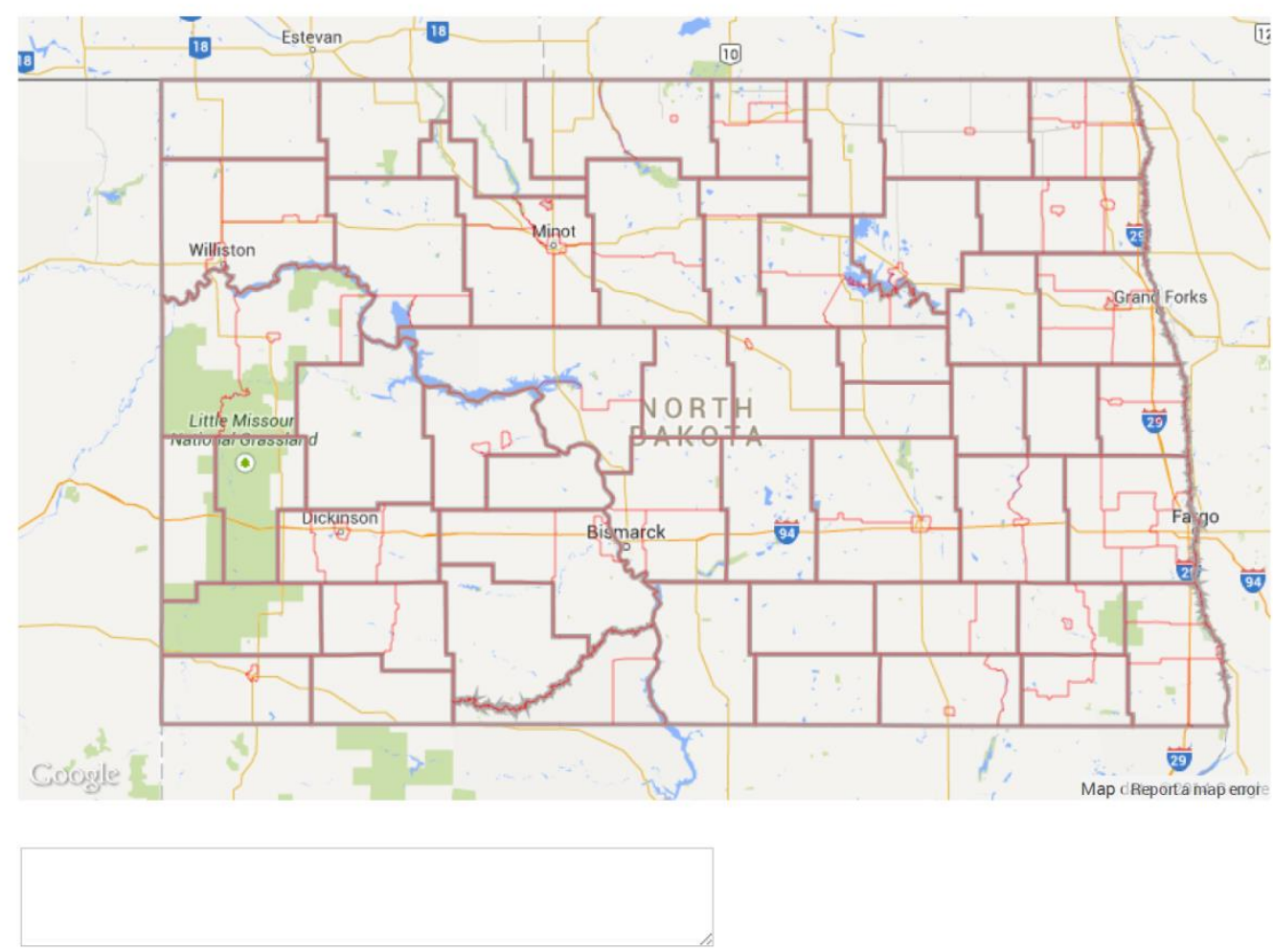

Continue 


\section{6}

\section{$\Delta 4$}

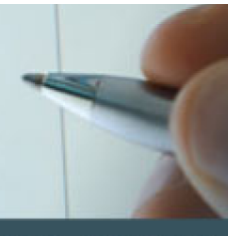

\section{NORTH DAKOTA TRANSIT LEVEL OF SERVICE AND NEEDS SURVEY}

Questions marked with an asterisk (*) are required.

9. *How is your ADA paratransit service area defined?

Operate within $3 / 4$ mile of fixed-route system

Operate within some other distance of the fixed-route system, please indicate distance:

Other, please describe your service area:

10. *Who is eligible to use your demand-response or paratransit service (check all that apply)?

$\square$ General public

People with disabilities

$\checkmark$ Senior citizens

$\square$ Others, please specify:

If you provide multiple types of services with different eligibility requirements, please explain:

11. *What is the minimum advance reservation time for your agency operating demand-response or complementary paratransit?

Up to $1 / 2$ hour

More than $1 / 2$ hour and up to 2 hours

More than 2 hours, but still same day

24 hours in advance, or prior service day

48 hours, or 2 days, in advance

More than 48 hours in advance, and up to 1 week

More than 1 week in advance, and up to 2 weeks

More than 2 weeks

12. *Is the minimum advance reservation time the same for all areas that your organization serves?

Yes

No, please explain:

13. *Please specify the approximate percentage of demand-response trip requests you have to turn down due to lack of capacity.
$0-1 \%$
$1-3 \%$
$3-5 \%$
$5-10 \%$
More than $10 \%$
Don't know/don't collect data 


\section{APPENDIX C. FRAMEWORK FOR DEVELOPING THE SURVEY AND THE MAP TOOL FOR NORTH DAKOTA TRANSIT AGENCIES}

The survey questions were built using standard HTML code and styled using Cascading Style Sheets (CSS). The Google Maps API was also used to make it easier for respondents to indicate which census tracts they serve. To show the census tract boundaries, two KMZ files were created using ArcGIS and layered over top the Google Map. Note that the census tracts were divided into two files to keep the files sizes low due to limitations set by the Google Maps API.

The problem with KMZ files is that Google Maps seems to be unable to make the individual tracts clickable. So the KMZ files needed to extract the KML files. This was accomplished by changing the file name from "layer1.kmz" to "layer1.zip" and effectively turning the files into ZIP files. The ZIP files can then be opened as normal and will contain a KML file.

The KML files were imported into Google Maps instead of the KMZ files. Some JavaScript code was developed to capture the map interactions and make sure the selected census tracts were marked in the corresponding survey questions. The JavaScript also removed the text values for census tracts that were unselected.

One drawback of using the Google Maps API and KML files is that the mapping solution doesn't provide any visual indication of which census tracts were selected. To supplement the solution so far, an add-on called GeoXML3 was employed. GeoXML3 provides the ability to fill the census-tract boundaries with color as they are being selected.

Another add-on called InfoBubble.js was used to show respondents an information bubble when the mouse cursor was placed over a census tract. The information bubble would display the name of a tract. The InfoBubble.js seemed necessary since there appeared to be a conflict between Google Map's information bubbles and the ones used by GeoXML3.

Once the map was fully functional, the PHP code was developed to process the form submission. Basically, the survey was split into two steps. The first step contained all the questions up to and including the map-related questions. Upon completing the first step, PHP saved the responses just in case the respondent stopped there. The second step contained all the rest of the questions. When that step was completed, PHP would verify the required questions were answered and it saved the responses if everything was filled out. Otherwise it would display the second step again. 


\title{
APPENDIX D. SURVEY TOOL USED FOR DEMAND-RESPONSE LEVEL OF SERVICE STUDY - FLORIDA
}

\author{
Organization name: \\ $A B C$ \\ Person completing survey: \\ Name: \\ Title: \\ City: \\ Email: \\ Phone number:
}

Florida Demand-Response Transit Survey

What types of transportation services does your organization provide (check all that apply)?

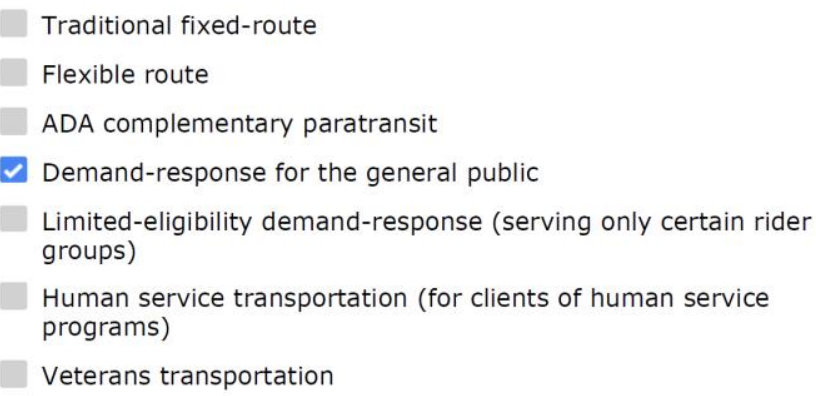

Do you provide the following types of services (check all that apply)?

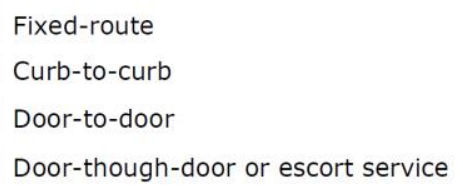

Proceed to the next page. Please expect minor delays (3-6 seconds) for the next page to load. 


\section{Florida Demand-Response Transit Survey}

Please select the county/counties where you provide demand response transit service or paratransit service.

\begin{tabular}{|c|c|c|c|}
\hline Alachua & Franklin & Lee & Pinellas \\
\hline Baker & Gadsden & Leon & Polk \\
\hline Bay & Gilchrist & Levy & Putnam \\
\hline Bradford & Glades & Liberty & Santa Rosa \\
\hline Brevard & Gulf & Madison & Sarasota \\
\hline Broward & Hamilton & Manatee & Seminole \\
\hline Calhoun & Hardee & Marion & St. Johns \\
\hline Charlotte & Hendry & Martin & St. Lucie \\
\hline Citrus & Hernando & Miami-Dade & Sumter \\
\hline Clay & Highlands & Monroe & Suwannee \\
\hline Collier & Hillsborough & Nassau & Taylor \\
\hline Columbia & Holmes & Okaloosa & Union \\
\hline DeSoto & Indian River & Okeechobee & Volusia \\
\hline Dixie & Jackson & Orange & Wakulla \\
\hline Duval & Jefferson & Osceola & Walton \\
\hline Escambia & Lafayette & Palm Beach & Washington \\
\hline Flagler & Lake & Pasco & \\
\hline
\end{tabular}

Proceed to the next page. Please expect minor delays (3-6 seconds) for the next page to load. 


\section{Florida Demand-Response Transit Survey}

Describe your transit service in Alachua County:

Our agency serves all of the county and provides the same number of days and hours of service throughout the county.

Our agency serves all of the county, but some areas have more days or hours of service than other areas.

Some areas of the county are not served by our agency.

Powered by Qualtrics

\section{Florida Demand-Response Transit Survey}

How many days per week and hours per day do you provide demand-response or paratransit service in Alachua County?

\begin{tabular}{|c|c|c|c|c|c|c|c|c|c|c|c|c|c|c|c|}
\hline & \multicolumn{9}{|c|}{ Days per week of service } & \multicolumn{6}{|c|}{ Hours of service per day } \\
\hline & $\begin{array}{c}7 \\
\text { day }\end{array}$ & $\begin{array}{c}6 \\
\text { days }\end{array}$ & $\begin{array}{c}5 \\
\text { days }\end{array}$ & $\begin{array}{c}4 \\
\text { days }\end{array}$ & $\begin{array}{c}3 \\
\text { days }\end{array}$ & $\begin{array}{c}2 \\
\text { days }\end{array}$ & $\begin{array}{c}1 \\
\text { day }\end{array}$ & $\begin{array}{l}\text { Less } \\
\text { than } \\
\text { weekly }\end{array}$ & $\begin{array}{c}\text { No } \\
\text { service }\end{array}$ & $\begin{array}{l}16 \text { or } \\
\text { more } \\
\text { hours }\end{array}$ & $\begin{array}{c}12- \\
15.9 \\
\text { hours }\end{array}$ & $\begin{array}{c}9- \\
11.9 \\
\text { hours }\end{array}$ & $\begin{array}{c}5- \\
8.9 \\
\text { hours }\end{array}$ & $\begin{array}{c}\text { Less } \\
\text { than } \\
5 \\
\text { hours }\end{array}$ & $\begin{array}{l}\text { No } \\
\text { service }\end{array}$ \\
\hline $\begin{array}{l}\text { Alachua } \\
\text { County }\end{array}$ & 0 & (1) & 0 & ( & O & ( & O & ( & O & O & (1) & O & O & O & 0 \\
\hline
\end{tabular}




\section{Florida Demand-Response Transit Survey}

\section{Describe your transit service in Alachua County:}

Our agency serves all of the county and provides the same number of days and hours of service throughout the county.

Our agency serves all of the county, but some areas have more days or hours of service than other areas.

Some areas of the county are not served by our agency.

\section{$\ll$}

Powered by Qualtrics

\section{Florida Demand-Response Transit Survey}

In Alachua County, how many days per week and hours per day do you provide demand-response or paratransit service in each of the following areas?

Note: Responses are mandatory for all the areas (communities). Please provide service details for all the areas to proceed to the next page.

\begin{tabular}{|c|c|c|c|c|c|c|c|c|c|c|c|c|c|c|c|}
\hline & \multicolumn{9}{|c|}{ Days per week of service } & \multicolumn{6}{|c|}{ Hours of service per day } \\
\hline & $\begin{array}{c}7 \\
\text { day }\end{array}$ & $\begin{array}{c}6 \\
\text { days }\end{array}$ & $\begin{array}{c}5 \\
\text { days }\end{array}$ & $\begin{array}{c}4 \\
\text { days }\end{array}$ & $\begin{array}{c}3 \\
\text { days }\end{array}$ & $\stackrel{2}{\text { days }}$ & $\begin{array}{c}1 \\
\text { day }\end{array}$ & $\begin{array}{c}\text { Less } \\
\text { than } \\
\text { weekly }\end{array}$ & $\begin{array}{c}\text { No } \\
\text { service }\end{array}$ & $\begin{array}{l}16 \text { or } \\
\text { more } \\
\text { hours }\end{array}$ & $\begin{array}{c}12- \\
15.9 \\
\text { hours }\end{array}$ & $\begin{array}{c}9- \\
11.9 \\
\text { hours }\end{array}$ & $\begin{array}{c}5- \\
8.9 \\
\text { hours }\end{array}$ & $\begin{array}{c}\text { Less } \\
\text { than } \\
5 \\
\text { hours }\end{array}$ & $\begin{array}{l}\text { No } \\
\text { service }\end{array}$ \\
\hline Alachua & O & O & O & O & O & O & O & O & ○ & O & O & O & O & O & O \\
\hline Archer & O & O & O & O & O & O & O & O & O & O & O & O & O & O & O \\
\hline Gainesville & O & O & O & O & O & O & O & O & O & O & O & O & O & O & O \\
\hline Hawthorne & O & O & O & O & O & O & O & O & O & O & O & O & O & O & ○ \\
\hline $\begin{array}{l}\text { High } \\
\text { Springs }\end{array}$ & O & O & O & O & O & O & O & O & O & O & O & O & O & O & O \\
\hline LaCrosse & O & O & O & O & O & O & 0 & O & O & O & O & O & O & O & O \\
\hline Micanopy & O & O & O & O & O & O & 0 & O & ○ & O & O & O & O & O & ○ \\
\hline Newberry & O & O & O & O & O & O & O & O & O & O & O & O & O & O & O \\
\hline Waldo & O & O & O & O & O & O & O & O & O & O & O & O & O & O & O \\
\hline $\begin{array}{l}\text { Other } \\
\text { Rural } \\
\text { Areas }\end{array}$ & 0 & 0 & 0 & 0 & 0 & 0 & 0 & 0 & 0 & 0 & 0 & 0 & 0 & 0 & 0 \\
\hline
\end{tabular}




\section{Florida Demand-Response Transit Survey}

Who is eligible to use your demand-response or paratransit service (check all that apply)?

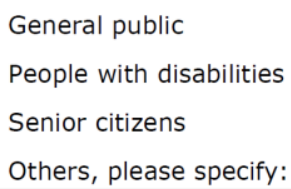

If you provide multiple types of services with different eligibility requirements, please explain:

What is the minimum advance reservation time for your agency operating demand-response or complementary paratransit?

Up to $1 / 2$ hour

More than $1 / 2$ hour and up to 2 hours

More than 2 hours, but still same day

24 hours in advance, or prior service day

48 hours, or 2 days, in advance

More than 48 hours in advance, and up to 1 week

More than 1 week in advance, and up to 2 weeks

More than 2 weeks

Is the minimum advance reservation time the same for all areas that your organization serves?

Yes

No, please explain:

Please describe the current fares you charge for your demandresponse or paratransit service.

Proceed to the next page. Please expect minor delays (3-6 seconds) for the next page to load. 


\section{Florida Demand-Response Transit Survey}

\begin{tabular}{l} 
Survey Feedback \\
How easy was it to complete the survey? \\
$\qquad \begin{array}{l}\text { Very } \\
\text { easy Easy } \begin{array}{c}\text { Somewhat } \\
\text { Easy }\end{array}\end{array}$ Neutral $\begin{array}{c}\text { Somewhat Difficult Difficult Difficult } \\
\text { survey was... }\end{array}$ \\
Were any of the questions difficult to answer or unclear? Please explain: \\
\hline
\end{tabular}


APPENDIX E. DETAILED DATA FOR FLORIDA

\begin{tabular}{|c|c|c|c|c|c|c|}
\hline \multirow[b]{2}{*}{ County } & \multirow[b]{2}{*}{ City } & \multicolumn{3}{|c|}{ Level of Service Details (all service) } & \multirow[b]{2}{*}{ Mobility Needs Index } & \multirow[b]{2}{*}{ Priority Rank } \\
\hline & & Days per Week & Hours per Day & LOS & & \\
\hline Alachua & Other Rural Areas & 6 & $9-11.9$ & 3 & 3.33 & 9 \\
\hline Alachua & Alachua & 7 & $9-11.9$ & 3 & 2.00 & 9 \\
\hline Alachua & Archer & 6 & $9-11.9$ & 3 & 2.00 & 9 \\
\hline Alachua & Gainesville & 7 & 16 or more & 1 & 4.33 & 9 \\
\hline Alachua & Hawthorne & 6 & $9-11.9$ & 3 & 1.33 & 10 \\
\hline Alachua & LaCrosse & 6 & $9-11.9$ & 3 & 2.00 & 9 \\
\hline Alachua & Micanopy & 6 & $9-11.9$ & 3 & 1.00 & 10 \\
\hline Alachua & Newberry & 6 & $9-11.9$ & 3 & 2.00 & 9 \\
\hline Alachua & Waldo & 6 & $9-11.9$ & 3 & 1.00 & 10 \\
\hline Baker & Other Rural Areas & 5 & $9-11.9$ & 4 & 1.00 & 9 \\
\hline Baker & Glen St. Mary & 5 & $9-11.9$ & 4 & 1.67 & 8 \\
\hline Baker & Macclenny & 5 & $9-11.9$ & 4 & 2.00 & 8 \\
\hline Bay & Other Rural Areas & 6 & $12-15.9$ & 2 & 3.67 & 8 \\
\hline Bay & Callaway & 6 & $12-15.9$ & 2 & 3.67 & 8 \\
\hline Bay & & 6 & $12-15.9$ & 2 & 1.00 & 10 \\
\hline Bay & Lynn Haven & 6 & $12-15.9$ & 2 & 4.00 & 8 \\
\hline Bay & Mexico Beach & No service & No service & 8 & 1.00 & 4 \\
\hline Bay & Panama City & 6 & $12-15.9$ & 2 & 2.67 & 9 \\
\hline Bay & Panama City Beach & 6 & $12-15.9$ & 2 & 2.00 & 9 \\
\hline Bay & Parker & 6 & $12-15.9$ & 2 & 4.00 & 8 \\
\hline Bay & Springfield & 6 & $12-15.9$ & 2 & 2.67 & 9 \\
\hline Bradford & Keystone Heights & & & & 1.67 & \\
\hline Bradford & Lawtey & & & & 2.00 & \\
\hline Bradford & Starke & & & & 2.67 & \\
\hline Brevard & Other Rural Areas & 6 & 16 or more & 1 & 3.00 & 9 \\
\hline Brevard & Cape Canaveral & 6 & 16 or more & 1 & 4.00 & 9 \\
\hline Brevard & Cocoa & 6 & 16 or more & 1 & 4.00 & 9 \\
\hline Brevard & Cocoa Beach & 6 & 16 or more & 1 & 3.67 & 9 \\
\hline Brevard & Grant-Valkaria & 6 & 16 or more & 1 & 3.00 & 9 \\
\hline Brevard & Melbourne & 6 & 16 or more & 1 & 4.67 & 8 \\
\hline Brevard & Melbourne Beach & 6 & 16 or more & 1 & 4.00 & 9 \\
\hline Brevard & Palm Bay & 6 & 16 or more & 1 & 4.00 & 9 \\
\hline Brevard & Palm Shores & 6 & 16 or more & 1 & 3.67 & 9 \\
\hline Brevard & Rockledge & 6 & 16 or more & 1 & 3.00 & 9 \\
\hline Brevard & Satellite Beach & 6 & 16 or more & 1 & 1.67 & 10 \\
\hline Brevard & Titusville & 6 & 16 or more & 1 & 3.00 & 9 \\
\hline Brevard & West Melbourne & 6 & 16 or more & 1 & 3.00 & 9 \\
\hline Broward & & 7 & 16 or more & 1 & 2.67 & 9 \\
\hline Broward & Coconut Creek & 7 & 16 or more & 1 & 5.00 & 8 \\
\hline Broward & Coral Springs & 7 & 16 or more & 1 & 5.00 & 8 \\
\hline Broward & Davie & 7 & 16 or more & 1 & 4.67 & 8 \\
\hline Broward & Deerfield Beach & 7 & 16 or more & 1 & 5.00 & 8 \\
\hline Broward & Fort Lauderdale & 7 & 16 or more & 1 & 5.00 & 8 \\
\hline Broward & Hallandale Beach & 7 & 16 or more & 1 & 5.00 & 8 \\
\hline Broward & Hollywood & 7 & 16 or more & 1 & 5.00 & 8 \\
\hline Broward & Lauderdale-by-the-Sea & 7 & 16 or more & 1 & 5.00 & 8 \\
\hline Broward & Lauderhill & 7 & 16 or more & 1 & 5.00 & 8 \\
\hline Broward & Lazy Lake & 7 & 16 or more & 1 & 5.00 & 8 \\
\hline Broward & Margate & 7 & 16 or more & 1 & 5.00 & 8 \\
\hline Broward & Miramar & 7 & 16 or more & 1 & 4.67 & 8 \\
\hline Broward & North Lauderdale & 7 & 16 or more & 1 & 5.00 & 8 \\
\hline Broward & Oakland Park & 7 & 16 or more & 1 & 5.00 & 8 \\
\hline Broward & Parkland & 7 & 16 or more & 1 & 4.00 & 9 \\
\hline Broward & Pembroke Park & 7 & 16 or more & 1 & 5.00 & 8 \\
\hline Broward & Pembroke Pines & 7 & 16 or more & 1 & 3.00 & 9 \\
\hline Broward & Plantation & 7 & 16 or more & 1 & 5.00 & 8 \\
\hline Broward & Pompano Beach & 7 & 16 or more & 1 & 5.00 & 8 \\
\hline Broward & Sea Ranch Lakes & 7 & 16 or more & 1 & 5.00 & 8 \\
\hline Broward & Southwest Ranches & 7 & 16 or more & 1 & 3.33 & 9 \\
\hline Broward & Sunrise & 7 & 16 or more & 1 & 5.00 & 8 \\
\hline Broward & Tamarac & 7 & 16 or more & 1 & 5.00 & 8 \\
\hline Broward & Weston & 7 & 16 or more & 1 & 4.00 & 9 \\
\hline
\end{tabular}




\begin{tabular}{|c|c|c|c|c|c|c|}
\hline Broward & Wilton Manors & 7 & 16 or more & 1 & 5.00 & 8 \\
\hline Calhoun & Other Rural Areas & & & & 1.00 & \\
\hline Calhoun & Altha & & & & 1.00 & \\
\hline Calhoun & Blountstown & & & & 1.67 & \\
\hline Charlotte & Other Rural Areas & 6 & $12-15.9$ & 2 & 2.67 & 9 \\
\hline Charlotte & & 6 & $12-15.9$ & 2 & 4.00 & 8 \\
\hline Charlotte & Punta Gorda & 6 & $12-15.9$ & 2 & 2.67 & 9 \\
\hline Citrus & Other Rural Areas & 5 & $9-11.9$ & 4 & 3.00 & 6 \\
\hline Citrus & Crystal River & 5 & $9-11.9$ & 4 & 3.00 & 6 \\
\hline Citrus & & 5 & $9-11.9$ & 4 & 3.00 & 6 \\
\hline Citrus & Inverness & 5 & $9-11.9$ & 4 & 3.00 & 6 \\
\hline Citrus & & 5 & $9-11.9$ & 4 & 2.00 & 8 \\
\hline Clay & Other Rural Areas & 6 & $12-15.9$ & 2 & 2.67 & 9 \\
\hline Clay & Green Cove Springs & 6 & $12-15.9$ & 2 & 2.00 & 9 \\
\hline Clay & & 6 & $12-15.9$ & 2 & 3.00 & 9 \\
\hline Clay & & 6 & $12-15.9$ & 2 & 2.67 & 9 \\
\hline Clay & Orange Park & 6 & $12-15.9$ & 2 & 4.00 & 8 \\
\hline Clay & Penney Farms & 6 & $12-15.9$ & 2 & 2.00 & 9 \\
\hline Collier & Other Rural Areas & 7 & $12-15.9$ & 2 & 3.67 & 8 \\
\hline Collier & & 7 & $12-15.9$ & 2 & 1.33 & 10 \\
\hline Collier & Everglades City & 7 & $12-15.9$ & 2 & 1.00 & 10 \\
\hline Collier & Marco Island & 7 & $12-15.9$ & 2 & 3.33 & 9 \\
\hline Collier & Naples & 7 & $12-15.9$ & 2 & 3.00 & 9 \\
\hline Columbia & Other Rural Areas & 6 & $12-15.9$ & 2 & 2.00 & 9 \\
\hline Columbia & Fort White & 6 & $12-15.9$ & 2 & 2.33 & 9 \\
\hline Columbia & & 6 & $12-15.9$ & 2 & 2.00 & 9 \\
\hline Columbia & Lake City & 6 & $12-15.9$ & 2 & 2.00 & 9 \\
\hline DeSoto & Other Rural Areas & & & & 1.67 & \\
\hline DeSoto & Arcadia & & & & 2.00 & \\
\hline Dixie & Other Rural Areas & & & & 1.00 & \\
\hline Dixie & Cross City & & & & 2.00 & \\
\hline Dixie & & & & & 1.00 & \\
\hline Duval & Jacksonville & 7 & 16 or more & 1 & 3.67 & 9 \\
\hline Duval & Jacksonville Beach & 7 & 16 or more & 1 & 4.33 & 9 \\
\hline Duval & Neptune Beach & 7 & 16 or more & 1 & 3.00 & 9 \\
\hline Escambia & Other Rural Areas & 6 & 16 or more & 1 & 3.00 & 9 \\
\hline Escambia & Century & 6 & 16 or more & 1 & 2.00 & 10 \\
\hline Escambia & & 6 & 16 or more & 1 & 2.00 & 10 \\
\hline Escambia & Pensacola & 6 & 16 or more & 1 & 4.00 & 9 \\
\hline Flagler & Other Rural Areas & 6 & $12-15.9$ & 2 & 1.00 & 10 \\
\hline Flagler & Flagler Beach & 6 & $12-15.9$ & 2 & 2.67 & 9 \\
\hline Flagler & Marineland & 6 & $12-15.9$ & 2 & 3.33 & 9 \\
\hline Flagler & & 6 & $12-15.9$ & 2 & 1.67 & 9 \\
\hline Flagler & & 6 & $12-15.9$ & 2 & 3.00 & 9 \\
\hline Franklin & Other Rural Areas & 6 & $12-15.9$ & 2 & 1.00 & 10 \\
\hline Franklin & Apalachicola & 6 & $12-15.9$ & 2 & 1.00 & 10 \\
\hline Franklin & Carrabelle & 6 & $12-15.9$ & 2 & 1.00 & 10 \\
\hline Gadsden & Chattahoochee & 6 & $12-15.9$ & 2 & 2.00 & 9 \\
\hline Gadsden & Gretna & 6 & $12-15.9$ & 2 & 1.33 & 10 \\
\hline Gadsden & Havana & 6 & $12-15.9$ & 2 & 2.33 & 9 \\
\hline Gadsden & Midway & 6 & $12-15.9$ & 2 & 1.33 & 10 \\
\hline Gadsden & Quincy & 6 & $12-15.9$ & 2 & 2.33 & 9 \\
\hline Gilchrist & Bell & & & & 1.67 & \\
\hline Gilchrist & Fanning Springs & & & & 2.00 & \\
\hline Gilchrist & & & & & 1.67 & \\
\hline Gilchrist & Trenton & & & & 2.00 & \\
\hline Glades & Other Rural Areas & 6 & $12-15.9$ & 2 & 1.00 & 10 \\
\hline Glades & & 6 & $12-15.9$ & 2 & 1.00 & 10 \\
\hline Glades & Moore Haven & 6 & $12-15.9$ & 2 & 1.00 & 10 \\
\hline Gulf & Port St. Joe & 7 & 16 or more & 1 & 1.00 & 10 \\
\hline Gulf & Wewahitchka & 7 & 16 or more & 1 & 1.00 & 10 \\
\hline Hamilton & Jasper & 6 & $12-15.9$ & 2 & 1.00 & 10 \\
\hline Hamilton & Jennings & 6 & $12-15.9$ & 2 & 1.00 & 10 \\
\hline Hamilton & White Springs & 6 & $12-15.9$ & 2 & 1.00 & 10 \\
\hline Hardee & Bowling Green & & & & 2.33 & 0 \\
\hline Hardee & Wauchula & & & & 1.33 & 0 \\
\hline
\end{tabular}




\begin{tabular}{|c|c|c|c|c|c|c|}
\hline Hardee & Zolfo Springs & & & & 1.00 & 0 \\
\hline Hendry & Other Rural Areas & 6 & $12-15.9$ & 2 & 1.00 & 10 \\
\hline Hendry & Clewiston & 6 & $12-15.9$ & 2 & 2.33 & 9 \\
\hline Hendry & LaBelle & 6 & $12-15.9$ & 2 & 1.00 & 10 \\
\hline Hernando & Other Rural Areas & 3 & $5-8.9$ & 5 & 3.00 & 5 \\
\hline Hernando & Brooksville & 5 & $9-11.9$ & 4 & 3.00 & 6 \\
\hline Hernando & Weeki Wachee & 5 & $9-11.9$ & 4 & 2.67 & 6 \\
\hline Highlands & Other Rural Areas & & & & 1.00 & \\
\hline Highlands & Avon Park & & & & 3.00 & \\
\hline Highlands & Lake Placid & & & & 2.00 & \\
\hline Highlands & Sebring & & & & 3.00 & \\
\hline Hillsborough & Other Rural Areas & 7 & 16 or more & 1 & 3.67 & 9 \\
\hline Hillsborough & & 7 & 16 or more & 1 & 4.00 & 9 \\
\hline Hillsborough & Plant City & 5 & $9-11.9$ & 4 & 3.33 & 6 \\
\hline Hillsborough & & 7 & 16 or more & 1 & 1.00 & 10 \\
\hline Hillsborough & Tampa & 7 & 16 or more & 1 & 4.33 & 9 \\
\hline Hillsborough & Temple Terrace & 7 & 16 or more & 1 & 4.67 & 8 \\
\hline Holmes & Bonifay & 7 & 16 or more & 1 & 2.00 & 10 \\
\hline Holmes & Noma & 7 & 16 or more & 1 & 1.00 & 10 \\
\hline Holmes & Westville & 7 & 16 or more & 1 & 1.00 & 10 \\
\hline Indian River & Other Rural Areas & 6 & $12-15.9$ & 2 & 3.00 & 9 \\
\hline Indian River & Fellsmere & 6 & $12-15.9$ & 2 & 1.00 & 10 \\
\hline Indian River & Orchid & 6 & $12-15.9$ & 2 & 3.00 & 9 \\
\hline Indian River & Sebastian & 6 & $12-15.9$ & 2 & 3.33 & 9 \\
\hline Indian River & Vero Beach & 6 & $12-15.9$ & 2 & 4.00 & 8 \\
\hline Jackson & & 7 & 16 or more & 1 & 2.00 & 10 \\
\hline Jackson & Graceville & 7 & 16 or more & 1 & 2.00 & 10 \\
\hline Jackson & Grand Ridge & 7 & 16 or more & 1 & 1.00 & 10 \\
\hline Jackson & Jacob City & 7 & 16 or more & 1 & 1.00 & 10 \\
\hline Jackson & Malone & 7 & 16 or more & 1 & 1.00 & 10 \\
\hline Jackson & Marianna & 7 & 16 or more & 1 & 2.00 & 10 \\
\hline Jefferson & Other Rural Areas & 6 & $12-15.9$ & 2 & 1.00 & 10 \\
\hline Jefferson & Monticello & 6 & $12-15.9$ & 2 & 1.00 & 10 \\
\hline Lafayette & Other Rural Areas & & & & 1.00 & \\
\hline Lafayette & Mayo & & & & 1.00 & \\
\hline Lake & Other Rural Areas & 5 & $12-15.9$ & 3 & 2.00 & 9 \\
\hline Lake & & 5 & $12-15.9$ & 3 & 2.00 & 9 \\
\hline Lake & Clermont & 5 & $12-15.9$ & 3 & 3.67 & 8 \\
\hline Lake & & 5 & $12-15.9$ & 3 & 1.00 & 10 \\
\hline Lake & Eustis & 5 & $12-15.9$ & 3 & 4.00 & 8 \\
\hline Lake & Howey-in-the-Hills & 5 & $12-15.9$ & 3 & 1.67 & 9 \\
\hline Lake & Lady Lake & 5 & $12-15.9$ & 3 & 4.00 & 8 \\
\hline Lake & Leesburg & 5 & $12-15.9$ & 3 & 3.67 & 8 \\
\hline Lake & Mascotte & 5 & $12-15.9$ & 3 & 2.00 & 9 \\
\hline Lake & Minneola & 5 & $12-15.9$ & 3 & 3.00 & 9 \\
\hline Lake & Montverde & 5 & $12-15.9$ & 3 & 1.67 & 9 \\
\hline Lake & Mount Dora & 5 & $12-15.9$ & 3 & 3.00 & 9 \\
\hline Lake & & 5 & $12-15.9$ & 3 & 4.00 & 8 \\
\hline Lake & Tavares & 5 & $12-15.9$ & 3 & 3.00 & 9 \\
\hline Lake & Umatilla & 5 & $12-15.9$ & 3 & 2.67 & 9 \\
\hline Lake & & 5 & $12-15.9$ & 3 & 3.00 & 9 \\
\hline Lake & & 5 & $12-15.9$ & 3 & 3.00 & 9 \\
\hline Lee & Other Rural Areas & No service & No service & 8 & 3.00 & 2 \\
\hline Lee & Bonita Springs & 7 & 16 or more & 1 & 3.67 & 9 \\
\hline Lee & Cape Coral & 7 & 16 or more & 1 & 4.00 & 9 \\
\hline Lee & Fort Myers & 7 & 16 or more & 1 & 4.00 & 9 \\
\hline Lee & Fort Myers Beach & 7 & 16 or more & 1 & 1.67 & 10 \\
\hline Lee & Sanibel & No service & No service & 8 & 2.00 & 3 \\
\hline Leon & Other Rural Areas & 7 & 16 or more & 1 & 1.00 & 10 \\
\hline Leon & & 7 & 16 or more & 1 & 3.33 & 9 \\
\hline Leon & Tallahassee & 7 & 16 or more & 1 & 3.33 & 9 \\
\hline Levy & Other Rural Areas & 6 & 16 or more & 1 & 1.00 & 10 \\
\hline Levy & Bronson & 6 & 16 or more & 1 & 2.00 & 10 \\
\hline Levy & Cedar Key & 6 & 16 or more & 1 & 1.00 & 10 \\
\hline Levy & Fanning Springs & 6 & 16 or more & 1 & 2.00 & 10 \\
\hline Levy & Otter Creek & 6 & 16 or more & 1 & 1.33 & 10 \\
\hline
\end{tabular}




\begin{tabular}{|c|c|c|}
\hline Levy & Williston & 6 \\
\hline Levy & Yankeetown & 2 \\
\hline Liberty & Other Rural Areas & 7 \\
\hline Liberty & Bristol & 7 \\
\hline Madison & Other Rural Areas & 6 \\
\hline Madison & Greenville & 6 \\
\hline Madison & Lee & 6 \\
\hline Madison & Madison & 6 \\
\hline Manatee & Other Rural Areas & 6 \\
\hline Manatee & Bradenton & 6 \\
\hline Manatee & Holmes Beach & 6 \\
\hline Manatee & Longboat Key & 6 \\
\hline Manatee & Palmetto & 6 \\
\hline \multicolumn{2}{|l|}{ Manatee } & 6 \\
\hline Marion & Other Rural Areas & 5 \\
\hline Marion & Belleview & 5 \\
\hline Marion & Dunnellon & 5 \\
\hline \multicolumn{2}{|l|}{ Marion } & 5 \\
\hline Marion & Ocala & 5 \\
\hline Marion & Reddick & 5 \\
\hline Martin & Other Rural Areas & 5 \\
\hline Martin & Jupiter Island & 5 \\
\hline Martin & Ocean Breeze & - \\
\hline \multicolumn{2}{|l|}{ Martin } & 5 \\
\hline Martin & Sewall's Point & 5 \\
\hline Martin & Stuart & 5 \\
\hline \multicolumn{2}{|l|}{ Martin } & \\
\hline Miami-Dade & Other Rural Areas & 7 \\
\hline Miami-Dade & Aventura & 7 \\
\hline Miami-Dade & Coral Gables & 7 \\
\hline Miami-Dade & Cutler Bay & 7 \\
\hline Miami-Dade & Doral & 7 \\
\hline Miami-Dade & El Portal & 7 \\
\hline Miami-Dade & Florida City & - \\
\hline \multicolumn{2}{|l|}{ Miami-Dade } & I \\
\hline Miami-Dade & Hialeah & - \\
\hline Miami-Dade & Hialeah Gardens & I \\
\hline Miami-Dade & Homestead & 7 \\
\hline \multicolumn{2}{|l|}{ Miami-Dade } & ' \\
\hline Miami-Dade & Key Biscayne & - \\
\hline Miami-Dade & Miami & 7 \\
\hline Miami-Dade & Miami Beach & 7 \\
\hline Miami-Dade & Miami Gardens & $\gamma$ \\
\hline Miami-Dade & Miami Lakes & . \\
\hline Miami-Dade & Miami Shores & 7 \\
\hline Miami-Dade & Miami Springs & 7 \\
\hline \multicolumn{2}{|l|}{ Miami-Dade } & $f^{\prime}$ \\
\hline Miami-Dade & North Bay Village & 7 \\
\hline Miami-Dade & North Miami & 7 \\
\hline Miami-Dade & North Miami Beach & 7 \\
\hline Miami-Dade & Opa-locka & $\gamma$ \\
\hline Miami-Dade & Palmetto Bay & 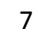 \\
\hline \multicolumn{2}{|l|}{ Miami-Dade } & 7 \\
\hline Miami-Dade & Pinecrest & 7 \\
\hline Miami-Dade & South Miami & I \\
\hline Miami-Dade & Sunny Isles Beach & I \\
\hline Miami-Dade & Surfside & 7 \\
\hline Miami-Dade & Sweetwater & 7 \\
\hline Miami-Dade & West Miami & 7 \\
\hline Monroe & Other Rural Areas & 3 \\
\hline Monroe & Islamorada & 3 \\
\hline \multicolumn{2}{|l|}{ Monroe } & 3 \\
\hline Monroe & Key West & 5 \\
\hline Monroe & Marathon & 5 \\
\hline Nassau & Other Rural Areas & 5 \\
\hline Nassau & Callahan & \\
\hline
\end{tabular}

\begin{tabular}{|c|c|c|c|}
\hline 16 or more & 1 & 2.00 & 10 \\
\hline 16 or more & 5 & 1.00 & 8 \\
\hline 16 or more & 1 & 1.00 & 10 \\
\hline 16 or more & 1 & 1.00 & 10 \\
\hline $12-15.9$ & 2 & 1.33 & 10 \\
\hline $12-15.9$ & 2 & 1.00 & 10 \\
\hline $12-15.9$ & 2 & 1.00 & 10 \\
\hline $12-15.9$ & 2 & 2.33 & 9 \\
\hline $12-15.9$ & 2 & 3.00 & 9 \\
\hline $12-15.9$ & 2 & 4.33 & 8 \\
\hline $12-15.9$ & 2 & 3.67 & 8 \\
\hline $12-15.9$ & 2 & 2.33 & 9 \\
\hline $12-15.9$ & 2 & 4.00 & 8 \\
\hline $12-15.9$ & 2 & 4.00 & 8 \\
\hline Less than 5 & 6 & 2.33 & 5 \\
\hline Less than 5 & 6 & 3.67 & 2 \\
\hline Less than 5 & 6 & 2.33 & 5 \\
\hline Less than 5 & 6 & 2.67 & 4 \\
\hline $5-8.9$ & 5 & 3.33 & 5 \\
\hline Less than 5 & 6 & 2.33 & 5 \\
\hline $9-11.9$ & 4 & 2.67 & 6 \\
\hline $9-11.9$ & 4 & 4.33 & 5 \\
\hline $9-11.9$ & 4 & 4.33 & 5 \\
\hline $9-11.9$ & 4 & 1.33 & 9 \\
\hline $9-11.9$ & 4 & 4.00 & 5 \\
\hline $9-11.9$ & 4 & 4.33 & 5 \\
\hline $9-11.9$ & 4 & 2.33 & 8 \\
\hline 16 or more & 1 & 5.00 & 8 \\
\hline 16 or more & 1 & 5.00 & 8 \\
\hline 16 or more & 1 & 5.00 & 8 \\
\hline 16 or more & 1 & 4.67 & 8 \\
\hline 16 or more & 1 & 4.33 & 9 \\
\hline 16 or more & 1 & 5.00 & 8 \\
\hline 16 or more & 1 & 1.33 & 10 \\
\hline 16 or more & 1 & 1.00 & 10 \\
\hline 16 or more & 1 & 5.00 & 8 \\
\hline 16 or more & 1 & 1.00 & 10 \\
\hline 16 or more & 1 & 4.33 & 9 \\
\hline 16 or more & 1 & 1.00 & 10 \\
\hline 16 or more & 1 & 3.33 & 9 \\
\hline 16 or more & 1 & 5.00 & 8 \\
\hline 16 or more & 1 & 5.00 & 8 \\
\hline 16 or more & 1 & 5.00 & 8 \\
\hline 16 or more & 1 & 5.00 & 8 \\
\hline 16 or more & 1 & 5.00 & 8 \\
\hline 16 or more & 1 & 5.00 & 8 \\
\hline 16 or more & 1 & 4.33 & 9 \\
\hline 16 or more & 1 & 4.67 & 8 \\
\hline 16 or more & 1 & 5.00 & 8 \\
\hline 16 or more & 1 & 5.00 & 8 \\
\hline 16 or more & 1 & 5.00 & 8 \\
\hline 16 or more & 1 & 4.67 & 8 \\
\hline 16 or more & 1 & 5.00 & 8 \\
\hline 16 or more & 1 & 4.00 & 9 \\
\hline 16 or more & 1 & 5.00 & 8 \\
\hline 16 or more & 1 & 5.00 & 8 \\
\hline 16 or more & 1 & 5.00 & 8 \\
\hline 16 or more & 1 & 4.67 & 8 \\
\hline 16 or more & 1 & 5.00 & 8 \\
\hline $5-8.9$ & 5 & 1.00 & 8 \\
\hline $5-8.9$ & 5 & 2.00 & 6 \\
\hline $5-8.9$ & 5 & 1.00 & 8 \\
\hline $5-8.9$ & 5 & 2.67 & 5 \\
\hline $5-8.9$ & 5 & 2.33 & 6 \\
\hline $9-11.9$ & 4 & 3.33 & 6 \\
\hline $9-11.9$ & 4 & 2.00 & 8 \\
\hline
\end{tabular}




\begin{tabular}{|c|c|c|c|c|c|c|}
\hline Nassau & Fernandina Beach & 5 & $9-11.9$ & 4 & 4.00 & 5 \\
\hline Nassau & Hilliard & 5 & $9-11.9$ & 4 & 1.00 & 9 \\
\hline Nassau & & 5 & $9-11.9$ & 4 & 2.00 & 8 \\
\hline Okaloosa & Other Rural Areas & 7 & $12-15.9$ & 2 & 2.00 & 9 \\
\hline Okaloosa & Crestview & 7 & $12-15.9$ & 2 & 3.33 & 9 \\
\hline Okaloosa & Destin & 7 & $12-15.9$ & 2 & 3.67 & 8 \\
\hline Okaloosa & Fort Walton Beach & 7 & $12-15.9$ & 2 & 3.33 & 9 \\
\hline Okaloosa & Laurel Hill & 7 & $12-15.9$ & 2 & 1.00 & 10 \\
\hline Okaloosa & Mary Esther & 7 & $12-15.9$ & 2 & 4.33 & 8 \\
\hline Okaloosa & Niceville & 7 & $12-15.9$ & 2 & 3.67 & 8 \\
\hline Okaloosa & Shalimar & 7 & $12-15.9$ & 2 & 4.33 & 8 \\
\hline Okaloosa & Valparaiso & 7 & $12-15.9$ & 2 & 1.00 & 10 \\
\hline Okeechobee & Other Rural Areas & & & & 1.00 & \\
\hline Okeechobee & Okeechobee & & & & 3.33 & \\
\hline Orange & Other Rural Areas & 7 & 16 or more & 1 & 3.67 & 9 \\
\hline Orange & & 7 & 16 or more & 1 & 4.67 & 8 \\
\hline Orange & Apopka & 7 & 16 or more & 1 & 3.67 & 9 \\
\hline Orange & & 7 & 16 or more & 1 & 5.00 & 8 \\
\hline Orange & Edgewood & 7 & 16 or more & 1 & 4.00 & 9 \\
\hline Orange & & 7 & 16 or more & 1 & 4.00 & 9 \\
\hline Orange & Lake Buena Vista & 7 & 16 or more & 1 & 2.33 & 10 \\
\hline Orange & Maitland & 7 & 16 or more & 1 & 3.00 & 9 \\
\hline Orange & Ocoee & 7 & 16 or more & 1 & 3.33 & 9 \\
\hline Orange & Orlando & 7 & 16 or more & 1 & 3.67 & 9 \\
\hline Orange & Windermere & 7 & 16 or more & 1 & 3.67 & 9 \\
\hline Orange & Winter Garden & 7 & 16 or more & 1 & 3.67 & 9 \\
\hline Orange & Winter Park & 7 & 16 or more & 1 & 5.00 & 8 \\
\hline Osceola & Other Rural Areas & 7 & 16 or more & 1 & 1.67 & 10 \\
\hline Osceola & & 7 & 16 or more & 1 & 2.00 & 10 \\
\hline Osceola & Kissimmee & 7 & 16 or more & 1 & 3.67 & 9 \\
\hline Osceola & St. Cloud & 7 & 16 or more & 1 & 3.00 & 9 \\
\hline Palm Beach & Other Rural Areas & 7 & 16 or more & 1 & 3.67 & 9 \\
\hline Palm Beach & Atlantis & 7 & 16 or more & 1 & 5.00 & 8 \\
\hline Palm Beach & Belle Glade & 7 & 16 or more & 1 & 3.33 & 9 \\
\hline Palm Beach & Boca Raton & 7 & 16 or more & 1 & 5.00 & 8 \\
\hline Palm Beach & Boynton Beach & 7 & 16 or more & 1 & 5.00 & 8 \\
\hline Palm Beach & & 7 & 16 or more & 1 & 5.00 & 8 \\
\hline Palm Beach & & 7 & 16 or more & 1 & 5.00 & 8 \\
\hline Palm Beach & Delray Beach & 7 & 16 or more & 1 & 5.00 & 8 \\
\hline Palm Beach & Golf & 7 & 16 or more & 1 & 4.67 & 8 \\
\hline Palm Beach & Greenacres & 7 & 16 or more & 1 & 5.00 & 8 \\
\hline Palm Beach & Gulf Stream & 7 & 16 or more & 1 & 5.00 & 8 \\
\hline Palm Beach & Haverhill & 7 & 16 or more & 1 & 4.67 & 8 \\
\hline Palm Beach & Highland Beach & 7 & 16 or more & 1 & 4.67 & 8 \\
\hline Palm Beach & Juno Beach & 7 & 16 or more & 1 & 4.67 & 8 \\
\hline Palm Beach & Jupiter & 7 & 16 or more & 1 & 4.67 & 8 \\
\hline Palm Beach & Jupiter Inlet Colony & 7 & 16 or more & 1 & 4.33 & 9 \\
\hline Palm Beach & Lake Park & 7 & 16 or more & 1 & 5.00 & 8 \\
\hline Palm Beach & Lake Worth & 7 & 16 or more & 1 & 5.00 & 8 \\
\hline Palm Beach & Lantana & 7 & 16 or more & 1 & 5.00 & 8 \\
\hline Palm Beach & Loxahatchee Groves & 7 & 16 or more & 1 & 3.00 & 9 \\
\hline Palm Beach & Manalapan & 7 & 16 or more & 1 & 5.00 & 8 \\
\hline Palm Beach & Ocean Ridge & 7 & 16 or more & 1 & 5.00 & 8 \\
\hline Palm Beach & Pahokee & 7 & 16 or more & 1 & 2.33 & 10 \\
\hline Palm Beach & Palm Beach & 7 & 16 or more & 1 & 5.00 & 8 \\
\hline Palm Beach & Palm Beach Gardens & 7 & 16 or more & 1 & 4.00 & 9 \\
\hline Palm Beach & Palm Springs & 7 & 16 or more & 1 & 5.00 & 8 \\
\hline Palm Beach & & 7 & 16 or more & 1 & 5.00 & 8 \\
\hline Palm Beach & Riviera Beach & 7 & 16 or more & 1 & 5.00 & 8 \\
\hline Palm Beach & Royal Palm Beach & 7 & 16 or more & 1 & 4.00 & 9 \\
\hline Palm Beach & South Bay & 7 & 16 or more & 1 & 1.33 & 10 \\
\hline Palm Beach & South Palm Beach & 7 & 16 or more & 1 & 1.33 & 10 \\
\hline Palm Beach & Tequesta & 7 & 16 or more & 1 & 4.33 & 9 \\
\hline Palm Beach & Wellington & 7 & 16 or more & 1 & 1.00 & 10 \\
\hline Palm Beach & West Palm Beach & 7 & 16 or more & 1 & 4.00 & 9 \\
\hline Pasco & Other Rural Areas & 5 & $12-15.9$ & 3 & 3.00 & 9 \\
\hline
\end{tabular}




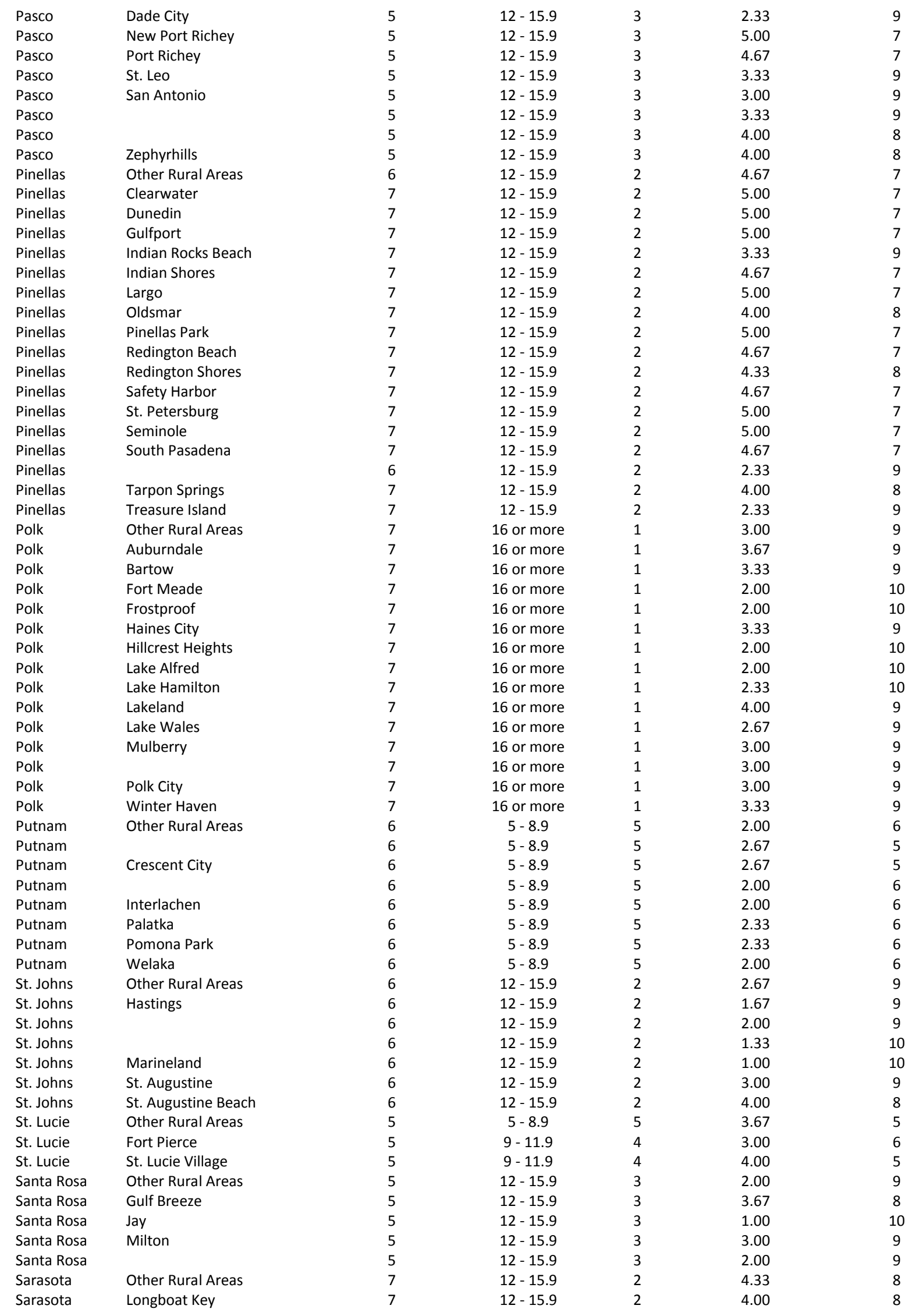




\begin{tabular}{|c|c|c|c|c|c|c|}
\hline Sarasota & North Port & 7 & $12-15.9$ & 2 & 3.67 & 8 \\
\hline Sarasota & Sarasota & 7 & $12-15.9$ & 2 & 3.67 & 8 \\
\hline Sarasota & Venice & 7 & $12-15.9$ & 2 & 2.67 & 9 \\
\hline Seminole & Other Rural Areas & 7 & 16 or more & 1 & 4.00 & 9 \\
\hline Seminole & Altamonte Springs & 7 & 16 or more & 1 & 5.00 & 8 \\
\hline Seminole & Casselberry & 7 & 16 or more & 1 & 5.00 & 8 \\
\hline Seminole & Lake Mary & 7 & 16 or more & 1 & 4.00 & 9 \\
\hline Seminole & Longwood & 7 & 16 or more & 1 & 4.00 & 9 \\
\hline Seminole & Oviedo & 7 & 16 or more & 1 & 3.00 & 9 \\
\hline Seminole & Sanford & 7 & 16 or more & 1 & 4.00 & 9 \\
\hline Seminole & Winter Springs & 7 & 16 or more & 1 & 4.00 & 9 \\
\hline Sumter & Other Rural Areas & & & & 2.33 & \\
\hline Sumter & Bushnell & & & & 2.00 & \\
\hline Sumter & Center Hill & & & & 2.00 & \\
\hline Sumter & Coleman & & & & 1.00 & \\
\hline Sumter & & & & & 4.67 & \\
\hline Sumter & Wildwood & & & & 3.67 & \\
\hline Suwannee & Other Rural Areas & 6 & $12-15.9$ & 2 & 1.33 & 10 \\
\hline Suwannee & Branford & 6 & $12-15.9$ & 2 & 2.00 & 9 \\
\hline Suwannee & Live Oak & 6 & $12-15.9$ & 2 & 2.33 & 9 \\
\hline Taylor & Other Rural Areas & 6 & $12-15.9$ & 2 & 1.00 & 10 \\
\hline Taylor & Perry & 6 & $12-15.9$ & 2 & 1.00 & 10 \\
\hline Union & Lake Butler & 5 & $12-15.9$ & 3 & 1.00 & 10 \\
\hline Union & Raiford & 5 & $12-15.9$ & 3 & 1.00 & 10 \\
\hline Union & Worthington Springs & 5 & $12-15.9$ & 3 & 1.33 & 10 \\
\hline Volusia & Other Rural Areas & 6 & $12-15.9$ & 2 & 3.67 & 8 \\
\hline Volusia & Daytona Beach & 7 & 16 or more & 1 & 3.33 & 9 \\
\hline Volusia & Daytona Beach Shores & 7 & 16 or more & 1 & 5.00 & 8 \\
\hline Volusia & DeBary & 6 & $12-15.9$ & 2 & 3.67 & 8 \\
\hline Volusia & DeLand & 6 & $12-15.9$ & 2 & 3.33 & 9 \\
\hline Volusia & Deltona & 6 & $12-15.9$ & 2 & 4.00 & 8 \\
\hline Volusia & Edgewater & 6 & $12-15.9$ & 2 & 4.00 & 8 \\
\hline Volusia & Holly Hill & 7 & $12-15.9$ & 2 & 5.00 & 7 \\
\hline Volusia & Lake Helen & 6 & $12-15.9$ & 2 & 3.00 & 9 \\
\hline Volusia & New Smyrna Beach & 6 & $12-15.9$ & 2 & 2.00 & 9 \\
\hline Volusia & Oak Hill & 6 & $12-15.9$ & 2 & 2.00 & 9 \\
\hline Volusia & Orange City & 6 & $12-15.9$ & 2 & 4.00 & 8 \\
\hline Volusia & Ormond Beach & 7 & $12-15.9$ & 2 & 4.00 & 8 \\
\hline Volusia & Pierson & 6 & $12-15.9$ & 2 & 1.00 & 10 \\
\hline Volusia & Ponce Inlet & 6 & $12-15.9$ & 2 & 1.33 & 10 \\
\hline Volusia & Port Orange & 7 & $12-15.9$ & 2 & 3.33 & 9 \\
\hline Volusia & & 6 & $12-15.9$ & 2 & 2.67 & 9 \\
\hline Volusia & South Daytona & 7 & $12-15.9$ & 2 & 5.00 & 7 \\
\hline Wakulla & Other Rural Areas & 7 & $9-11.9$ & 3 & 1.67 & 9 \\
\hline Wakulla & St. Marks & 7 & $9-11.9$ & 3 & 1.00 & 10 \\
\hline Wakulla & Sopchoppy & 7 & $9-11.9$ & 3 & 1.00 & 10 \\
\hline Walton & Other Rural Areas & 7 & 16 or more & 1 & 1.00 & 10 \\
\hline Walton & DeFuniak Springs & 7 & 16 or more & 1 & 3.00 & 9 \\
\hline Walton & & 7 & 16 or more & 1 & 2.33 & 10 \\
\hline Walton & & 7 & 16 or more & 1 & 1.00 & 10 \\
\hline Walton & Freeport & 7 & 16 or more & 1 & 1.00 & 10 \\
\hline Walton & Paxton & 7 & 16 or more & 1 & 1.67 & 10 \\
\hline Walton & & 7 & 16 or more & 1 & 1.00 & 10 \\
\hline Washington & Other Rural Areas & 7 & 16 or more & 1 & 1.00 & 10 \\
\hline Washington & Chipley & 7 & 16 or more & 1 & 2.00 & 10 \\
\hline Washington & Vernon & 7 & 16 or more & 1 & 1.00 & 10 \\
\hline Washington & Wausau & 7 & 16 or more & 1 & 1.00 & 10 \\
\hline Washington & & 7 & 16 or more & 1 & 1.00 & 10 \\
\hline
\end{tabular}

